Boletín de la Sociedad Geológica MeXicana,

TOMO LIV, 2001, P. 28-66

\title{
Tectonic history of the Chihuahua trough, Mexico and adjacent USA, Part I: the pre-Mesozoic setting
}

\author{
Walter T. Haenggi \\ 2007 Tradewinds Drive, Missouri City, TX 77459-2331 \\ Whaen83675@aol.com
}

\begin{abstract}
Elements of a broad zone of northwesterly-trending lineaments, along the southwest margin of the North American craton, have been recurrently active since Middle Proterozoic time. Stratigraphic and structural data indicate the influence of this zone on Paleozoic, Mesozoic, Tertiary and Recent geology of northeastern Chihuahua.

The Carrizo Mountain Group (estimated age 1,400-1,300 Ma) must have been deposited in a basin (northwesttrending graben?). Sparse examples of "older" granitic rocks ( $c a$. 1,350-1,270 Ma) suggest widespread magmatism over a large area of Chihuahua, that is in part coeval with emplacement of granitic rocks to the north. The Carrizo Mountain Group depositional basin (graben?) may be the earliest manifestation of the dominant northwesterly-trending structural grain of the region; timing is consistent with oldest known strike-slip movement along the Texas Lineament zone (Stockton Pass, Arizona ca. 1,370 $\pm 70 \mathrm{Ma}$ ).

Following deposition of the Carrizo Mountain Group, inferred 1,260-1,160 Ma De Baca rifting affected areas to the north and northwest of the present Carrizo Mountain Group outcrop and subcrop. The rift probably extended into northern Chihuahua and metasedimentary rocks record a marine incursion; presumably from an ocean to the south. It is postulated that the De Baca/Swisher metasedimentary and basaltic rocks represent an intracontinental rift and that there is a genetic relationship between them and the Midcontinent rift. At about the same time as rifting, rocks of the Carrizo Mountain Group underwent their first metamorphism. At around 1,100 Ma, the region was subjected to "Grenville" diastrophism that includes extensive batholith emplacement, thrust faulting, retrograde metamorphism and synorogenic deposition of the Hazel Formation.

Pre-Mississippian Paleozoic rocks of the region are the consequence of widespread cratonic shelf deposition along a relatively passive margin of the North American craton. Cambrian and Ordovician rocks include basal transgressive sandstones that reflect a general northeastern advance of seas onto North America. The major event during the early Paleozoic was a change in the boundary of the North American craton during Ordovician time. At about 450 Ma, the Cuyania terrane was separated from the craton and eventually was attached to South America. Local Ordovician, Silurian and Devonian faulting in Texas and New Mexico and disconformities on the Diablo Platform and in central New Mexico indicate periods of shelf exposure. These features may reflect tectonism over large areas, including northern Chihuahua, but their origin and significance is not clear.

Four late Paleozoic tectonic pulses, affecting the Ouachita-Marathon system, are recognized in northeastern Chihuahua and adjacent parts of the United States: 1) Mississippian-Pennsylvanian deformation in Ouachita hinterland; 2) Pennsylvanian orogeny; 3) Pennsylvanian-Permian folding and thrusting; 4) Permian erosion/truncation and subsequent tilting
\end{abstract}

Keywords: Chihuahua trough, stratigraphy, tectonics, Precambrian, Paleozoic

\section{Resumen}

Las estructuras de una amplia zona de lineamientos de orientación noroeste, localizada a lo largo del margen suroeste del cratón de Norteamérica, han estado activos recurrentemente desde el Proterozoico Medio. Los datos estratigráficos y estructurales indican la influencia de esta zona en la geología del Paleozoico, Mesozoico, Terciario y Re- 
ciente del noreste de Chihuahua.

El Carrizo Mountain Group, con edad estimada en 1,400 a 1,300 Ma, debe haberse depositado en una cuenca (¿graben de orientación noroeste?). Ejemplos aislados de rocas graníticas "antiguas" (ca. 1,350 - 1,270 Ma) sugieren magmatismo distribuido en una amplia área de Chihuahua, que en parte es coetáneo con el emplazamiento de rocas graníticas hacia el norte. La cuenca (¿graben?) del Carrizo Mountain Group puede ser la primera manifestación del grano estructural de orientación noroeste que domina en la región. La edad es consistente con la de los movimientos de fallas laterales más antiguos a lo largo de la zona del Texas Lineament (Stockton Pass, Arizona, ca. 1,370 70 Ma).

Siguiendo al depósito del Carrizo Mountain Group, áreas al norte y noroeste de la zona donde se encuentra este grupo fueron afectadas por el inferido De Baca rift a 1,260-1,160 Ma. El rift probablemente se extendió hasta la parte norte de Chihuahua y las rocas metasedimentarias registran incursiones marinas, presumiblemente desde un océano localizado hacia el sur. Se postula que las rocas metasedimentarias y basálticas De Baca/Swisher representan un rift intracontinental y que existe una relación genética entre ellas y el rift Midcontinental. Aproximadamente al mismo tiempo en que ocurría el rifting, un primer evento metamórfico afectó a las rocas del Carrizo Mountain Group. Alrededor de los 1,100 Ma, la región fue sujeta al diastrofismo "Grenville", que incluyó emplazamiento extensivo de batolitos, cabalgamientos, metamorfismo retrógrado y el depósito sinorogénico de la Formación Hazel.

Las rocas paleozoicas pre-misisípicas de la región fueron la consecuencia de la depositación distribuida ampliamente en la plataforma cratónica, a lo largo de un margen relativamente pasivo del cratón de Norteamérica. Rocas cámbricas y ordovícicas incluyen areniscas basales transgresivas que reflejan un avance general hacia el noreste de los mares sobre Norteamérica. El evento más importante durante el Paleozoico temprano, fue un cambio en el límite del cratón norteamericano durante el Ordovícico. Aproximadamente a los $450 \mathrm{Ma}$, el terreno Cuyania se separó del cratón y eventualmente fue acrecionado a Sudamérica. El fallamiento local del Ordovícico, Silúrico y Devónico en Texas y Nuevo México, y las discordancias en la Diablo Platform y en la parte central de Nuevo México, indican eventos de exposición de la plataforma. Estas características pueden reflejar actividad tectónica en grandes áreas, incluyendo la parte norte de Chihuahua, pero su origen y significado aún no es claro.

Cuatro pulsos tectónicos del Paleozoico tardío, que afectaron al sistema Ouachita-Marathon, se reconocen en el noreste de Chihuahua y zonas adyacentes de Estados Unidos: 1) deformación en el postpaís del Ouachita durante el Misisípico-Pensilvánico; 2) orogenia pensilvánica; 3 ) plegamiento y cabalgamiento del Pensilvánico-Pérmico; 4) erosión/ truncación del Pérmico y basculamiento subsecuente.

Palabras clave: Cuenca de Chihuahua, estratigrafía, tectónica, Precámbrico, Paleozoico.

\section{Introducción}

The Chihuahua trough, a Mesozoic depositional basin occupying northeastern Chihuahua and adjacent parts of Texas, New Mexico and extreme northeastern Sonora, has a long and complex tectonic history. This report on the pre-Mesozoic history of the general area of the trough describes what is known and provides interpretations of data and some speculations that can be tested by field work and drilling. To gain insight into the preMesozoic history of the trough area, it is necessary to speculate on the Precambrian and Early to Middle Paleozoic history of the region and to describe Late Paleozoic events affecting the Aldama and Diablo platforms and Marfa and Pedregosa basins. The Late Paleozoic Pedregosa basin is, in effect, a proto-Chihuahua trough.

\subsection{Definition of the Chihuahua trough}

DeFord (1964) first used the term "Chihuahua trough" and intended it to be the depositional basin that was inverted to form the Laramide Chihuahua tectonic belt (Cohee, 1961). The extent of Chihuahua trough as definied by DeFord is uncertain, e.g. "Perhaps the un- conformity near Aldama records only the western shore of an arm of the sea that invaded the Chihuahua trough. Or perhaps it records the eastern shore of the western counterpart of the Coahuila Peninsula." This discussion of pre-Mesozoic events is concerned with the area that became the Chihuahua trough (see Figure 1). The Chihuahua trough is herein defined as the area of northeastern Chihuahua and adjacent parts of Texas, New Mexico and Sonora that later became sites of a pre-Albian Mesozoic basin. An arbitrary southern boundary is placed at the edge of the North American craton as defined by lead isotope data (James and Henry, 1993) and the Alamitos lineament, an arbitrary northwestern limit is selected along the 109th Meridian (the pre-Albian basin extends beyond these boundaries to the south into Coahuila and to the west into Arizona and Sonora).

\subsection{Lineaments}

Along the southwestern margin of the North American craton there is a zone of northwest-trending lineaments. Lineament is used here in the sense of Hobbs et al. (1976), "A linear topographic feature of regional extent that is believed to reflect crustal structure." As 

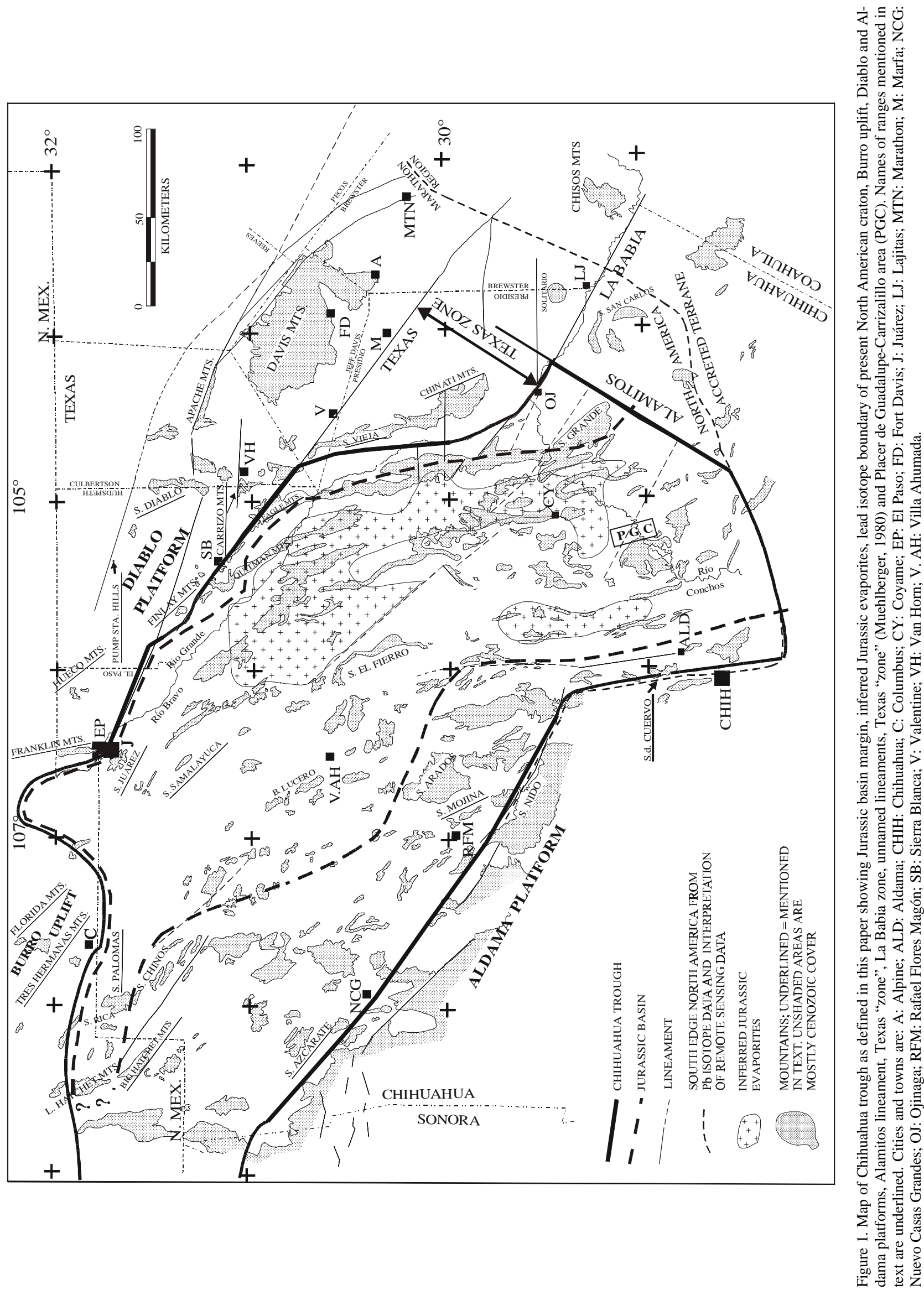
noted by Hills (1963), in the early stages of an investigation, when the knowledge of geology of a region is meager and where maps and air photos are available, it will be obvious that physiographic trends shown by streams, ridges and shorelines exhibit a certain geometrical regularity, notably in the parallelism of straight features. Although geological data may be quite inadequate to determine the exact nature of delineated features, lineaments afford valuable information by identifying localities where more information is needed and by providing a tectonic framework for structural and stratigraphic analysis.

The approach of this study is to use lineaments and physiographic features shown on Space Shuttle photographs and satellite imagery as tools for interpreting regional geology. The attempt is to define zones of crustal weakness, to verify definition of lineaments indicated by geological and geophysical maps and to evaluate faults, megashears, structural highs and lows, as described by other workers. Data from wells drilled in and around the Chihuahua trough have been collected from many sources and subsurface interpretations of structural and stratigraphic data from them have been integrated into the interpretations presented here. Table 1 lists wells shown by the figures in this paper and discussed in the text.

The general concept of northwest-trending lineaments presented herein leans heavily on the interpretations of many authors, Goetz and Dickerson (1985), Muehlberger (1965, 1980), Murray (1986), Silver and Anderson (1974), Stevens et al. (1992), and Stewart and Roldán-Quintana (1991) among others. The zone of the northwest-trending lineaments has been intermittently active from the late Precambrian until the present day, as indicated by sporadic earthquakes occurring along the trend in Texas from Valentine to Marathon (see Figure 1 for locations). On satellite and Space Shuttle imagery, an active fault scarp is visible along the La Babia zone in Chihuahua, some 15 kilometers southeast of Lajitas, Texas (see Figure 1 for locations).

\section{Precambrian}

Within the area of the Chihuahua trough, Precambrian rocks crop out in two places; 1) clasts in Mesozoic units in Sierra Mojina and Sierra Juárez, and 2) reported from PEMEX wells Los Chinos-1, Ojinaga-1 and Moyotes-1 (Table 2). In Texas and New Mexico, adjacent to the trough, Precambrian rocks are found in at least 15 wells (Figure 2): the Franklin Mountains, Hueco Mountains, Carrizo Mountains and in the Pump Station Hills (Figure 1). There is no evidence that the trough, as defined here, is underlain by any other than Proterozoic North American basement rocks.

Proterozoic faulting near the Chihuahua trough is documented only in Trans-Pecos Texas by thrusting along the Neoproterozoic Streeruwitz fault, by a left- lateral separation of units in the Hazel Formation, along the west-northwest trending Grapevine fault, some nine kilometers north of the Streeruwitz thrust (Figure 2) and, possibly, by several west-northwest faults occurring only in the Allamoore and Hazel formations of the Sierra Diablo Area (Figure 1; King, 1965). Swan (1975) reported left-lateral Mesoproterozoic movement along a northwest-trending fault near Stockton Pass in Arizona (located about 90 kilometers northwest of the northwest corner of Figure 2).

Mapped faults, lineations and linear gravity features that are interpreted to be associated with a zone of fundamental crustal weakness along the southwestern margin of the North American craton are shown in Figure 2. Within and along the margins of the Chihuahua trough, the prevailing trend in this zone is north 50 to $60^{\circ}$ west. Several authors have speculated that a 500-kilometer wide zone of west-northwest to northwest-trending faulting extending from Arizona to Texas had its inception in the Precambrian (Albritton and Smith, 1957; Baker, 1934, Drewes, 1981; Swan, 1975). There is general agreement that the zone is the surface expression of crustal weaknesses. Goetz and Dickerson (1985) suggested that it is a manifestation of a late ProterozoicPaleozoic transform margin of North America. Faults of this zone have been reactivated at various times and individually and collectively have diverse movements. There has been much controversy in their interpretation. In this paper, activity of this zone will be invoked to explain late Paleozoic and Mesozoic tectonic elements affecting the area of the Chihuahua trough and it is assumed that the zone began to develop during the Precambrian.

Figure 2 shows a postulated boundary of the North American craton at the end of Proterozoic time. The boundary of the craton from the La Babia zone to south of Chihuahua City is based on a study of lead isotopes by James and Henry (1993) that they interpreted to delineate a boundary between the North American craton to the northwest and late Paleozoic accreted terranes to the southeast. The present boundary of North American crust, northeast of the La Babia zone, is also shown in Figure 2 and it should be noted that this boundary and a portion of the boundary in Chihuahua is subparallel to the "Alamitos zone," a clearly defined lineation on satellite and space shuttle imagery, that trends northnortheast, orthogonal to the prevailing trend of the crustal weakness zone. On the imagery, the "Alamitos zone" can be traced from the Chihuahua trough to the northwestern end of the Glass Mountains (extension not shown by Figure 2).

The craton boundary shown on Figure 2 from south of Chihuahua City trending north and thence westnorthwest to the Chihuahua-Sonora border is based on studies of satellite and Space Shuttle imagery, gravity maps, and interpretations of Paleozoic paleogeography.

At the end of the Proterozoic, North America to the northeast of the La Babia zone was probably more extensive than now. During the early Paleozoic, in the 
Table 1. Wells shown on Figures.

\begin{tabular}{|c|c|c|c|c|c|}
\hline Well & Operator & Symbol & Well & Operator & Symbol \\
\hline \multicolumn{3}{|l|}{ COAHUILA } & \multicolumn{3}{|c|}{ HUDSPETH COUNTY, TEXAS } \\
\hline$\overline{\text { Concordia-1 }}$ & PEMEX & Concordia-1 & Bask State “9”-1 & Border Expl. & BSK 9 \\
\hline \multicolumn{3}{|l|}{ CHIHUAHUA } & Burner State "B"-1 & Gulf & BUR \\
\hline Apache-1 & PEMEX & AP-1 & Briggs-1 & \\
\hline Asensión-1 & PEMEX & ASC-1 & C.L. Ranch-1 & Haymond Krupp BRIGGS & CL R \\
\hline Banco Lucero-1 & PEMEX & BL-1 & Emmett-1 & Texaco & EM \\
\hline Camello-1 & PEMEX & CAM-1 & Gard. and Mosley-1 & \multicolumn{2}{|c|}{ Western States G\&M-1 } \\
\hline Centauro-1 & PEMEX & CEN-1 & Gilmore-1 & Pogo & GIL \\
\hline Chapo-1 & PEMEX & $\mathrm{CH}-1$ & Haas-1 & \multicolumn{2}{|c|}{ Pan-American HAAS } \\
\hline Chapo-2 & PEMEX & $\mathrm{CH}-2$ & Hammack et al.-1 & Border Expl. & BX HAM \\
\hline Cuchillo Parado-1 & PEMEX & $\mathrm{CP}-1$ & Hammack-1 & Pan-American & HAM \\
\hline Cuchillo Parado-2 & PEMEX & $\mathrm{CP}-2$ & List Anderson-1 & Pan-American & L AND \\
\hline El Hueso-1 & PEMEX & $\mathrm{EH}-1$ & Merril-Voyes-1 & General Crude & MV \\
\hline Espía-1 & PEMEX & ESP-1 & Mowry-1 & Jones & MOWRY \\
\hline Juárez-1 \&1A & PEMEX & JU-1 & MSA-1 & Transocean & MSA \\
\hline Los Chinos-1 & PEMEX & LC-1 & State " $26 ”-1$ & Border Explorati & ion $\quad 26-1$ \\
\hline Menonita-1 & PEMEX & MEN-1 & State "FV"-1 & Texaco & ST FV \\
\hline Maijoma-1 & PEMEX & MJ-1 & State "11"-1 & Border Explorati & ion ST 11-1 \\
\hline Moyotes-1 & PEMEX & MOY-1 & Thaxton-1 & Haymond Krupp & THX-1 \\
\hline Ojinaga-1 & PEMEX & $\mathrm{OJ}-1$ & University “M-49”-1 & Hunt & U M-49 \\
\hline Pilares-1 & PEMEX & PIL-1 & & & \\
\hline Presidio-1 & PEMEX & PR-1 & JEFF DAVIS COUN & TEXAS & \\
\hline Samalayuca-1 and $1 \mathrm{~A}$ & PEMEX & SAM-1 & "Continental-1" & Continental & CONT \\
\hline Sapallo-1 & PEMEX & SAP-1 & "Plymouth-1" & Plymouth & PLY \\
\hline Villa Ahumada-1 & PEMEX & VA-1 & "Stanolind-1A" & Stanolind & ST-1A \\
\hline NEW MEXICO & & & & & \\
\hline$\overline{\text { Alpha-Federal-1 }}$ & Dunigan & A FED & PECOS COUNTY, $T$ & & \\
\hline Federal "H"-1 & Pure & PU "H" & Allison-1 & Continental & $\mathrm{AL}$ \\
\hline Mobil “32”-1 & Grimm & $32-1$ & Cox-1 & Mobil & $\operatorname{COX}$ \\
\hline McMillen-1A & Union & MM-1A & Moore-1 & Forrest & MO \\
\hline McMillen-Turner-1 & Hunt & MM TUR & Sibley-1 & Mobil & SIB \\
\hline New Mexico "C"-1 & Skelly & SK-1 & & & \\
\hline N. M. Fed. "R"-1 & Sunray & SUN-1 & PRESIDIO COUNT & EXAS & \\
\hline State "BA"-1 & Humble & ST BA & Alpha 21-1 & $\mathrm{HNG}$ & A $21-1$ \\
\hline State-1F & Turner & ST $1 \mathrm{~F}$ & Birdsall-1 & West & BIRD \\
\hline BREWSTER COUNT & TEXAS & & Bledsoe-1 & West & BSOE \\
\hline Adams-1 & Mobil & ADMS & Brite-1 & Welch & BRITE \\
\hline Catto-Gage-1 & Clark Drilling & CAT G & Brite-4 Fee & Brite & B-4 \\
\hline Combs-1 & Gulf & G. COMBS & Espy-1 & Welch & ESPY \\
\hline Combs-1 & Turner & T. COMBS & Evans-1 & Sinclair/Worth & EVANS \\
\hline Decie 1-47 & Slick/Urschell & DEC & FNBFW "F"-1 & Gulf & B FW \\
\hline Dodson-1 & Texas American & DOD & Holmes-1 & Tucker & HOL \\
\hline Law-1 & Exxon & LAW & Hubbard-1 & Gulf & HUB \\
\hline Lippitt-1 & Gulf & LIP & Kennedy-1 & Exxon & KEN \\
\hline Lykes-1, 2 \& 3 & Shannon & S LK & Lykes State-1 & Union & U LK \\
\hline McElroy-1 & Sun & McEL & Mitchell-1 & Gulf & G MITCH \\
\hline West-1 & Pure & WEST & Mitchell-1 & Phillips & P MITCH \\
\hline CULBERTSON COU & Y, TEXAS & & Moody-Hutchins-1 & Amoco & M HUTCH \\
\hline Cockrell-1 & Cosden & COCK & Presidio State-1 & Arco & P ST \\
\hline Foster-1 & Continental & FOS & Presidio Trust-1 & Gulf & G. PTR \\
\hline Grisham-1 & Gulf & GRIS & Presidio Trust-1 & Hunt & H PTR \\
\hline Looney-1 & Sinclair & LOON & Presidio Trust-1 & West & W. PTR \\
\hline Madera-Broman-1 & Mobil & MDR & Presidio Trust-1 & West/Cockburn & WC PTR \\
\hline Montgomery-1 & El Paso & MONT & Simpson-1 & El Paso NG & SIMP \\
\hline Potter-1 & Huber & POT & St. School "Lo"-1 & Gulf & $\mathrm{S} \mathrm{SCH}$ \\
\hline Rey. Cattle "B"-1 & Humble & REY B1 & Swafford-1 & Gulf & SWA \\
\hline Rounsaville-1 & American Quasar & rROUN & Thomas "139"-1 & Miller Brothers & THMAS \\
\hline Stansbury-1 & La Gloria & STANS & Widow Unit-1 & Texaco & WU \\
\hline EL PASO COUNTY, & $\underline{\text { XAS }}$ & & & & \\
\hline Dorough-1 & Mobil & DOR & REEVES COUNTY, & $\underline{\mathrm{XAS}}$ & \\
\hline St. Univ. "DW"-1 & Humble & ST DW & "Standard"-2 $\quad$ Sta & & ST-2 \\
\hline Surratt-1 & Chambers/Kenne & edy $\quad$ SUR-1 & & & \\
\hline
\end{tabular}


Table 2. Precambrian rocks of Northeastern Chihuahua and adjacent areas.

\begin{tabular}{|c|c|c|c|c|}
\hline Rock type & Age-Method & Location (symbol) & Ocurrence & Reference \\
\hline Granite & $1,327 \pm 242 \mathrm{Ma}, \mathrm{Rb}-\mathrm{Sr}$ & Los Chinos-1 (LC-1) & Well penetration & PEMEX, 1973 personal communication \\
\hline Granite & $890 \pm 32 \mathrm{Ma}, \mathrm{Rb}-\mathrm{Sr}$ & Moyotes-1 (MOY-1) & Well penetration & PEMEX, 1973 personal communication \\
\hline "Granite" & $977 \pm 78 \mathrm{Ma}, \mathrm{Rb}-\mathrm{Sr}$ & Ojinaga-1 (OJ-1) & Well penetration & Limón González., 1986 \\
\hline Granite & $\sim 886 \mathrm{Ma}, \mathrm{K}-\mathrm{Ar}$ & Gulf Burner "B"-1 (BUR) V & Well penetration & Dennison and Hetherington, 1969 \\
\hline Metagabbro & $1,333+10 /-8 \mathrm{Ma}, \mathrm{U}-\mathrm{Pb}$ & Sierra del Cuervo & Outcrop & Mosher, 1998 (citation) \\
\hline Metagranite & $1,274+6 /-5 \mathrm{Ma}, \mathrm{U}-\mathrm{Pb}$ & Sierra del Cuervo & Outcrop & Mosher, 1998 (citation) \\
\hline Trondhjemite & $1,080 \pm 5 \mathrm{Ma}, \mathrm{U}-\mathrm{Pb}$ & Sierra del Cuervo & Outcrop & Mosher, 1998 (citation) \\
\hline $\begin{array}{l}\text { Metagranite, gneiss, } \\
\text { amphibloite, and } \\
\text { Trondhjemite }\end{array}$ & Undated & Carrizalillo & Outcrop & Reyes-Cortés and Potter, 1987 \\
\hline Rhyolite & $1,111 \pm 43 \mathrm{Ma}, \mathrm{U}-\mathrm{Pb}$ & Franklin Mountains & Thunderbird Rhyolite & Mosher, 1998 (citation) \\
\hline Granite & $1,120 \pm 35 \mathrm{Ma}, \mathrm{U}-\mathrm{Pb}$ & Franklin Mountains & Red Bluff Granite & Mosher, 1998 (citation) \\
\hline Granite & $1,086 \pm 5 \mathrm{Ma}, \mathrm{U}-\mathrm{Pb}$ & Franklin Mountains & Red Bluff Granite & Mosher, 1998 (citation) \\
\hline Felsic tuff & $1,260 \pm 20 \mathrm{Ma}, \mathrm{U}-\mathrm{Pb}$ & Franklin Mountains & in Castner Marble & Mosher, 1998 (citation) \\
\hline Granite & 1,200 to $1,150 \mathrm{Ma}, \mathrm{U}-\mathrm{Pb}$ & Franklin Mountains & Red Bluff Granite & Wasserburg et al., 1962 \\
\hline Granite & $1,050 \pm 60 \mathrm{Ma}, \mathrm{Rb}-\mathrm{Sr}$ & Hueco Mountains & Outcrop & Wasserburg et al., 1962 \\
\hline Rhyolite & 1,200 to $1,150 \mathrm{Ma}, \mathrm{U}-\mathrm{Pb}$ & Pump Station Hills & Outcrop & Wasserburg et al., 1962 \\
\hline Granite? & $950 \pm 25 \mathrm{Ma}, ? ? ?$ & $\begin{array}{l}\text { Hunt McMillan-Turner-1 } \\
\text { (MM TUR) }\end{array}$ & Well penetration & $\begin{array}{l}\text { Black, } 1976 \text { ("radiometric date" } \\
\text { noted on cross section) }\end{array}$ \\
\hline Granite? & Undated & Turner State-1F (ST 1F) & Well penetration & Black, 1976 \\
\hline Sandstone & Hazel Formation & $\begin{array}{l}\text { Pan-American List- } \\
\text { Anderson-1 (L AND) }\end{array}$ & Well penetration & Veldhuis and Keller, 1980 \\
\hline "Precambrian" & & $\begin{array}{l}\text { Hunt University M-49”-1 } \\
\text { (U M-49) }\end{array}$ & Well penetration & Veldhuis and Keller, 1980 \\
\hline "Precambrian" & Carrizo Mtn. Group? & Cosden Cockrell-1 (COCK) & Well penetration & Veldhuis and Keller, 1980 \\
\hline Granite & Undated & $\begin{array}{l}\text { Miller Brothers Thomas } \\
\text { "139"-1 (THMAS) }\end{array}$ & Well penetration & Pearson, 1985 \\
\hline Granite/gneiss & 950 Ma., ??? & $\begin{array}{l}\text { Gulf Swafford-1 (SWA) \& } \\
\text { Hunt Presidio Trust-1 } \\
\text { (H PTR) }\end{array}$ & Well penetrations & $\begin{array}{l}\text { Muehlberger and Dickerson, } 1989 \text {; } \\
\text { shown as Llano province by } \\
\text { Denison } \text { et al., } 1984\end{array}$ \\
\hline Rhyolite & $1,380 \pm 20 \mathrm{Ma}, \mathrm{U}-\mathrm{Pb}$ & Carrizo Mountains & Carrizo Mtn. Group & Mosher, 1998 (citation) \\
\hline Rhyolite & $1,370 \mathrm{Ma}, \mathrm{U}-\mathrm{Pb}$ & Carrizo Mountains & Carrizo Mtn. Group & Mosher, 1998 (citation) \\
\hline Rhyolite & $1,327 \pm 28 \mathrm{Ma}, \mathrm{U}-\mathrm{Pb}$ & Carrizo Mountains & Carrizo Mtn. Group & Mosher, 1998 (citation) \\
\hline Felsic tuff & $1,256 \pm 5 \mathrm{Ma}, \mathrm{U}-\mathrm{Pb}$ & Sierra Diablo & In Allamoore Fm. & Mosher, 1998 (citation) \\
\hline Felsic tuff & $1,247 \pm 4 \mathrm{Ma}, \mathrm{U}-\mathrm{Pb}$ & Sierra Diablo & In Allamoore Fm. & Mosher, 1998 (citation) \\
\hline Granite & $1,123 \pm 29 \mathrm{Ma}, \mathrm{U}-\mathrm{Pb}$ & Sierra Diablo & Clast in Hazel Fm. & Mosher, 1998 (citation) \\
\hline Rhyolite & $1,12 \pm 23 \mathrm{Ma}, \mathrm{U}-\mathrm{Pb}$ & Sierra Diablo & Clast in Hazel Fm. & Mosher, 1998 (citation) \\
\hline
\end{tabular}


Table 2. Cont.

\begin{tabular}{|c|c|c|c|c|}
\hline Rock type & Age-Method & Location (symbol) & Ocurrence & Reference \\
\hline Amphibolite & $917 \pm 47 \mathrm{Ma}, \mathrm{K}-\mathrm{Ar}$ & $\begin{array}{l}\text { Border Exploration State } \\
\text { "11"-1 (ST 11-1) }\end{array}$ & Well penetration & Setter and Adams, 1986 \\
\hline Metamorphic & Carrizo Mtn. Group & $\begin{array}{l}\text { Texaco State "FV"-1 } \\
\text { (ST FV) }\end{array}$ & Well penetration & $\begin{array}{l}\text { Texaco, } 1998 \text { personal } \\
\text { communication }\end{array}$ \\
\hline Metamorphic & Carrizo Mtn. Group & $\begin{array}{l}\text { Gulf First Natl. Bank of } \\
\text { Ft. Worth-1 (B FW) }\end{array}$ & Well penetration & $\begin{array}{l}\text { Gulf Oil Co., pre- } 1984 \text { personal } \\
\text { communication }\end{array}$ \\
\hline "Granite wash" & & $\begin{array}{l}\text { Sinclair/Worth Evans-1 } \\
\text { (EVANS) }\end{array}$ & Well penetration & $\begin{array}{l}\text { Gulf Oil Co., pre- } 1984 \text { personal } \\
\text { communication }\end{array}$ \\
\hline Granite & Undated & Welsh Espy-1 (ESPY) & Well penetration & $\begin{array}{l}\text { Gulf Oil Co., pre- } 1984 \text { personal } \\
\text { communication }\end{array}$ \\
\hline Metarhyolite & $700 \pm 100 \mathrm{Ma}, \mathrm{Rb}-\mathrm{Sr}$ & Sierra Mojina & $\begin{array}{l}\text { Clasts in basal } \\
\text { Mesozoic Cgl. }\end{array}$ & Denison et al., 1970 \\
\hline Granite & $1,270 \pm 45 \mathrm{Ma}, \mathrm{Rb}-\mathrm{Sr}$ & Sierra Juárez & $\begin{array}{l}\text { Pebbles in Lower } \\
\text { Cretaceous Cuchillo Fm. }\end{array}$ & Denison et al., 1970 \\
\hline
\end{tabular}

area labeled Cuyania terrane (Figures 2 and 3), a twosided basin (Marathon/Solitario basin) developed on continental crust along a passive margin of North America and extended an unknown distance toward the southeast. The interpretation of the La Babia zone as the southwestern limit of Cuyania is based on 1) Paleozoic rocks exposed in the Minas Plomosas-Carrizalillo area and in the Sierra del Cuervo, near Aldama, show no evidence of a southern source area and hence, no continental source in that direction, and 2) the apparent termination of the Ouachita-Marathon fold belt at the La Babia zone, ergo, only the northwestern part of the CambrianOrdovician two-sided basin extended to the southwest into Chihuahua. This termination of Lower to MidPaleozoic and Upper Paleozoic Ouachita facies rocks is described by King (1975), as a prominent discontinuity, of undetermined character and is interpreted here as a northwest-trending zone of crustal weakness (continental transform) that had its inception during Precambrian time.

\subsection{Occurrences}

Denison et al. (1984) have mapped Precambrian rocks in the United States adjacent to Chihuahua. A north-northeast trending 1,000 - 1,100 Ma zone of metasedimentary and basaltic rock (De Baca-Swisher) is mapped between older granitic units in southeastern New Mexico and far west Texas (De Baca rift in Figure 2). Their map shows the De Baca-Swisher subcrop pattern orthogonal to a 1,000 Ma igneous unit (Franklin Mountains) along the Texas-New Mexico border north and east of El Paso, and 1,250 (?) Ma Carrizo Mountain
Group rocks in the vicinity of Van Horn, Texas. South of the Carrizo Mountain Group, along the Rio Grande in Presidio County, Texas, a western extension of 1,0501,200 Ma Llano Province granitic rocks is mapped. Figure 2 extends this map into Mexico to show postulated "older granitic" rocks and an "Expanded Franklin Mountains" igneous unit that ultimately joins with Llano Province rocks south and west of Marfa, Texas. Table 2 lists rock types, for dated occurrences of Precambrian rocks in Chihuahua and adjacent areas.

\subsection{Speculations}

The 1,400-1,300 Ma deposition of Carrizo Mountain Group rocks and intrusion of 1,350-1,270 Ma granitic rocks found in PEMEX Los Chinos-1 (LC-1) and at Sierra del Cuervo are the earliest recorded events in northeastern Chihuahua. Around 1,260 Ma, De Baca rifting affected areas to the north and can be inferred to extend into Chihuahua. At about the same time rocks of the Carrizo Mountain Group underwent their first metamorphism. Around 1,100 Ma the region was subjected to "Grenville" diastrophism that includes extensive batholith emplacement (Franklin Mountains igneous group and Llano Province), Streeruwitz thrusting, retrograde metamorphism of the Carrizo Mountain Group and synorogenic deposition of the Hazel Formation.

\subsection{De Baca Rift Hypothesis}

Denison et al. (1984) speculated that sedimentary rocks of the De Baca-Swisher metasedimentary/basaltic unit were deposited just prior to extrusion of rhyolite in the Franklin Mountains, perhaps 1,100-1,000 Ma. U-Pb 


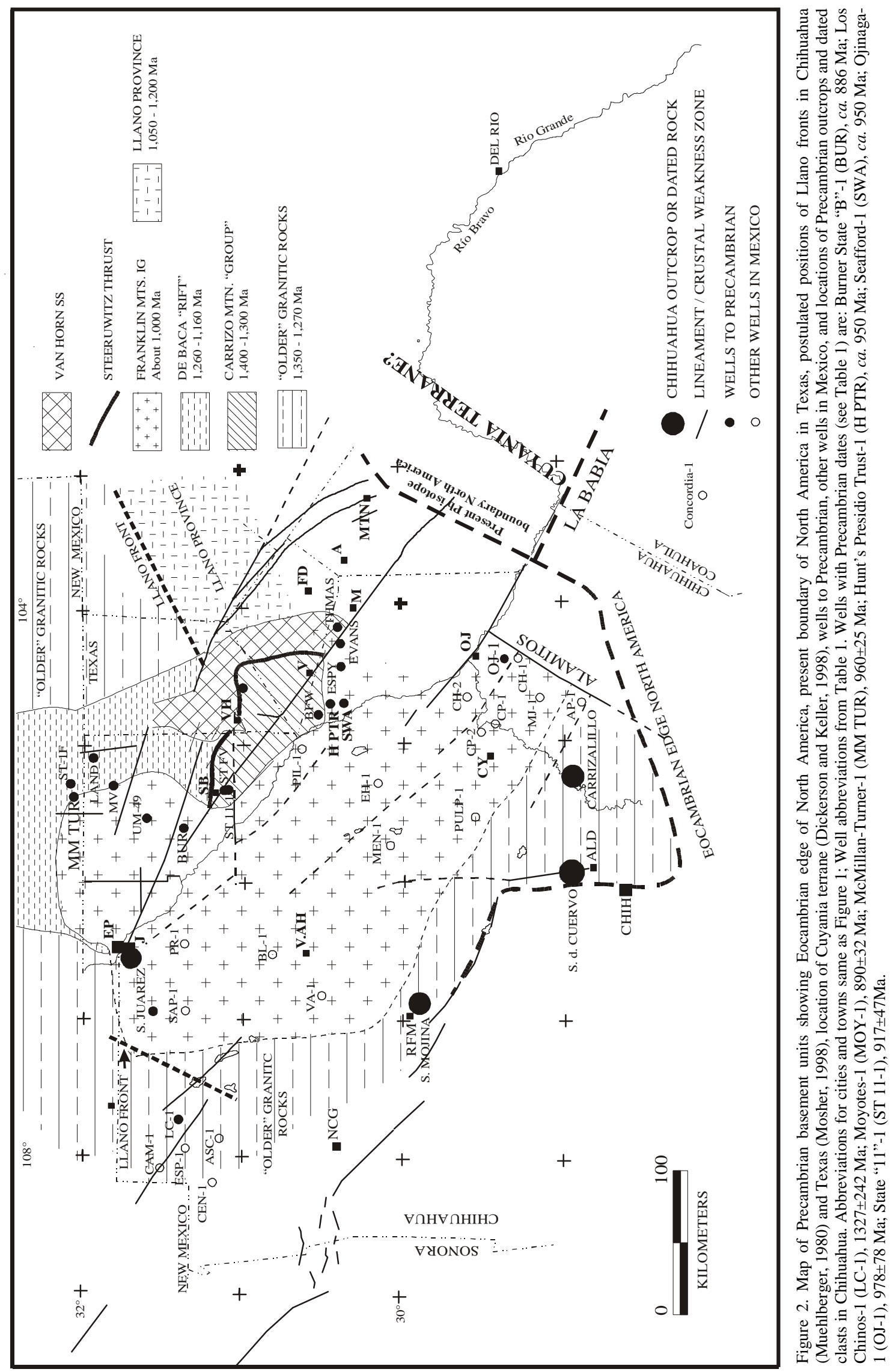




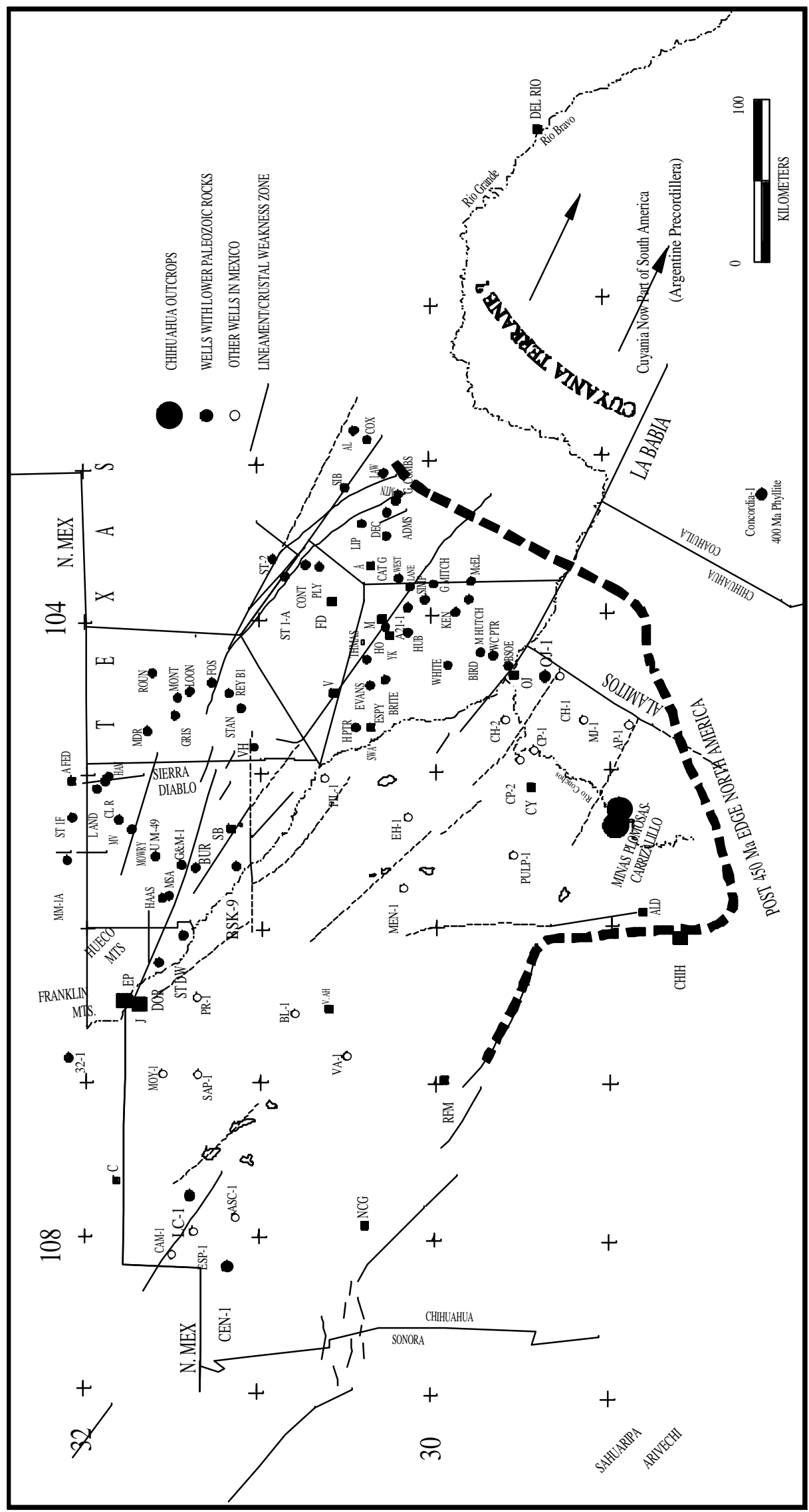

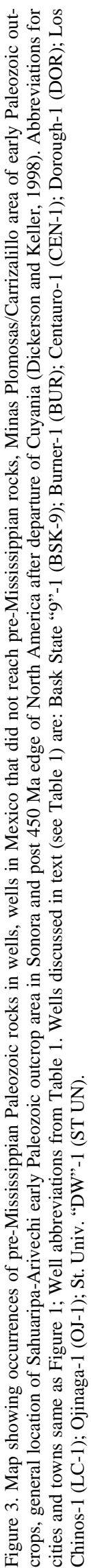


dates for tuffs in units of the De Baca section (cited by Mosher, 1998) are 1,260 \pm 60 Ma (Castner marble), $1,247 \pm 4$, and $1,256 \pm 5 \mathrm{Ma}$ (Allamoore Formation). These $\mathrm{U}-\mathrm{Pb}$ data suggest that the De Baca age estimate of Denison et al. (1984), which is based on Rb-Sr and K-Ar dates, can be pushed back some 160 Ma to $1,260-1,160$ Ma. A well drilled into Swisher diabasic rocks (Gulf Keliehor-1, Parmer County, Texas) has a 1,200 Ma K-Ar date (Muehlberger et al., 1967). The Hazel Formation, a syntectonic unit deposited during deformation related to Streeruwitz thrusting, and the Van Horn Sandstone, a post-Streeruwitz thrusting unit, are not included here in De Baca metasedimentary units although the present outcrop area of the Hazel Formation is within the area of the Van Horn Sandstone and De Baca map units on Figure 2 and several authors, notably Denison (1980), included it in the De Baca terrane. The Hazel is younger than $\sim 1,120 \mathrm{Ma}$ (U-Pb dates from granite and rhyolite boulders cited by Mosher, 1998).

Formation of the Midcontinent rift was contemporaneous with northwest-directed crustal-scale thrusting of the Grenville orogen of Ontario, Canada, around 1,100 Ma, implying a mechanical linkage between crustal thickening in the orogen and thinning in the foreland (Hoffman, 1989). Gordon and Hempton (1986) presented arguments for the Keeweenawan rift forming as a result of convergence during the Grenville Orogeny and related rifting to a series of pull-apart basins between northwest-trending, left-lateral strike slip faults developed in the continent ahead of the collision front. They estimated, from "the best U-Pb and $\mathrm{Rb}-\mathrm{Sr}$ dates," that the Grenville Orogeny existed from 1,150 to $1,100 \mathrm{Ma}$ and Keeweenawan rifting occurred 1,120-1,100 Ma. According to Weiblen (1993), the beginning and ending of Keeweenawan rifting is indeterminate (documented dates on Keeweenawan rocks range from 1,340 $\pm 33 \mathrm{Ma}$ to $884 \pm 75 \mathrm{Ma}$ ). De Baca/Swisher metasedimentary and basaltic rocks are on trend with the Midcontinent rift and formed during a comparable time (estimated 1,260-1,160 Ma). In far west Texas, metasedimentary rocks of marine origin occur in the De Baca section, viz. Allamoore Formation, Castner Marble. Toward the north, sedimentary rocks become increasingly arkosic and are probably nonmarine and the amount of basaltic rocks increases becoming predominant in the Swisher diabasic group of rocks. A possible relationship between the Swisher diabases and Keeweenawan basalts was suggested by Eardley (1962). He pointed out that the characteristic positive gravity anomalies of the Midcontinent rift are not present over the De Baca/Swisher metasedimentary and basaltic rocks. The Hazel Formation directly overlies rocks of the De Baca section (Allamoore Formation) and is a syntectonic unit formed as a consequence of a Grenville orogenic event, the Streeruwitz thrust.

The Keeweenawan/Midcontinent rift and the De Baca/Swisher sections formed at similar times, contain continental clastic rocks and basalts, occupy narrow elongate belts within older cratonic rocks, and can be related in time and space to Grenville orogenesis. It seems reasonable to postulate that the De Baca/Swisher units represent an intracontinental rift and that there is a genetic relationship between it and the Midcontinent rift.

\subsubsection{Carrizo Mountain Group}

Flawn (1953) described two periods of metamorphism of rocks of the Carrizo Mountain Group: 1) Regional progressive metamorphism decreasing in intensity northwestward and 2) Retrogressive and cataclastic metamorphism with a striking areal relation to the Streeruwitz thrust. He speculated that emplacement of rhyolite succeeded progressive metamorphism and was followed by cataclastic and retrogressive metamorphism that caused retrogression of metamorphic facies in sedimentary rocks in the northwest part of the outcrop area. Finally, diorite was intruded into metarhyolite and metasedimentary rocks and was altered to amphibolite during late stages of cataclastic metamorphism and culmination of thrusting.

Structural analysis of Reynolds (1985) recognized two periods of deformation of the Carrizo Mountain Group: 1) 1,220 $\pm 67 \mathrm{Ma}$ (Rb-Sr) deformation accompanying metamorphism of rhyolite, and 2) A "younger Allamoore-Hazel" episode that is associated with the Streeruwitz thrust.

Mosher (1998) cited $\mathrm{U} / \mathrm{Pb}$ dates of $1,380 \pm 20$ to $1,327 \pm 28 \mathrm{Ma}$ for rhyolite and suggested that metadiabase (amphibolite) and granodiorite are "pretectonic." She noted that timing of syn-metamorphic deformation and relation to thrusting are poorly constrained; 1 ) The Carrizo Mountain Group was metamorphosed and polydeformed after $\sim 1,300 \mathrm{Ma}$ and prior to thrusting over foreland sediments (Allamoore Formation) and 2) thrusting within the sediments occurred after $\sim 1,123 \mathrm{Ma}$ (age of clast in synorogenic Hazel Formation), and perhaps between 1,100 and 1,080 Ma (based on paleomagnetic data from synorogenic sediments). Mosher stated that several lines of evidence suggest that polyphase deformation of the Carrizo Mountain Group and thrusting of foreland sedimentary rocks and synorogenic sedimentation are part of a long period $(\sim 1,300-\sim 1,123 \mathrm{Ma})$ of progressive deformation that culminated in their juxtaposition along the Streeruwitz thrust.

Denison (1980) observed; "Age of deposition of Carrizo Mountain Group can be best approximated by determination of the age of the metarhyolites." If a substantial part of the rhyolite is extrusive, as Denison suspected, the age of the Carrizo Mountain Group can be closely approximated and he concluded that the Carrizo Mountain sediments were deposited 1,300-1,200 Ma. Using similar logic and applying $\mathrm{U}-\mathrm{Pb}$ dates from tuffs in the presumably younger Allamoore Formation and metarhyolite from the Carrizo Mountain Group, cited by Mosher (1998), estimated time of deposition of the Carrizo Mountain Group is 1,400-1,300 Ma. Age of latest metamorphism and shearing from $\mathrm{K}-\mathrm{Ar}$ and $\mathrm{Rb}-\mathrm{Sr}$ dates by Wasserburg et al. (1962) and Denison et al. (1984) is 
estimated to be about 1,000 Ma. An amphibolite, cored in Border Exploration State "11"-1 (ST 11-1), was dated at $917 \pm 47 \mathrm{Ma}$ (K-Ar, Setter and Adams, 1986). U-Pb dates from clasts in the syntectonic Hazel Formation and relations between igneous events at Sierra del Cuervo, Chihuahua, are interpreted by Mosher (1998) to indicate thrusting at 1,123-1,080 Ma. Thrusting was certainly prior to deposition of the Van Horn Sandstone that is generally regarded to be a latest Proterozoic formation that lies unconformably across the Streeruwitz thrust.

\subsubsection{Grenville Events}

The "1,100 Ma" event (Streeruwitz thrusting, retrograde and cataclastic metamorphism) in the Carrizo Mountains is coeval with Franklin Mountain igneous activity and intrusion of some granite in the Llano Province. Flawn (1953) speculated that an original igneous rock in the Carrizo Mountains, probably a diorite, injected during cataclastic metamorphism, was converted to amphibolite (included in Carrizo Mountain Group) during later stages of the metamorphism. He further speculated that the youngest Precambrian metaigneous rock, a granodiorite that shows only incipient cataclastic metamorphism, is probably a late phase of the diorite magma. Cataclastic metamorphism seems inadequate to convert diorite to amphibolite; dynamothermal metamorphism, involving a heat source other than friction, must be involved in this process. If Flawn (1953) is correct in his relative time of emplacement of diorite and subsequent conversion to amphibolite, the amphibolite protolith and granodiorite of the Carrizo Mountains can be included in the Franklin Mountains igneous suite.

Dates from Moyotes-1 (MOY-1) and Ojinaga-1 (OJ1) in Mexico, suggest that the Franklin Mountains igneous and coeval Llano Province granitic rocks mapped by Denison et al. (1984) extend into northeastern Chihuahua. These rocks may be parts of a single large "Grenville" batholith in Chihuahua and adjacent TransPecos, Texas, that occupies a large portion of the Mesozoic Chihuahua trough and would provide a heat source for dynamothermal metamorphism during the " 1,100 Ma" event. The youngest Precambrian igneous rocks in the Sierra del Cuervo and at Cerro Carrizalillo (trondhjemites) occur in a zone peripheral to and are derived from magmas associated with this "Grenville" batholith. Mosher (1998) projected the Llano front, a southwest-trending magnetic/gravity anomaly in Texas, similar to the Grenville front of the Appalachians, across northeastern Chihuahua with no change in trend. Available data does not support nor preclude this extension. The metarhyolite clasts at Sierra Mojina may be 1) derived from a part of the Franklin Mountains igneous rocks, 2) be evidence of a post-Grenville rift, or 3) be derived from an accreted terrane. Older granite, encountered in Los Chinos-1 (LC-1), may be part of an "older" Granitic Gneiss unit ("1,600 Ma") mapped to the north by Denison et al. (1984).

For the sake of completeness, it should be noted that
"Grenville" age rocks in areas surrounded by 1,650 to 1,190 Ma rocks (various $\mathrm{Rb}-\mathrm{Sr}$ and $\mathrm{U}-\mathrm{Pb}$ zircon dates) were reported by Clemons and Mack (1988) in New Mexico. In areas adjacent to the Chihuahua trough, they mentioned dates in New Mexico for aplite and granite in the Big Hatchet Mountains (950 Ma Rb-Sr) and altered granite and aplite in the Peloncillo Mountains (immediately west of northwestern part of Figure 1) ranging between 776 and 1,262 $\mathrm{Ma}(\mathrm{Rb}-\mathrm{Sr})$.

\subsubsection{Recapitulation}

1,400-1,300 Ma is the best estimate for deposition of the Carrizo Mountain Group and the postulated 1,260 Ma De Baca rifting gets underway about the same time as the first metamorphism of the Carrizo Mountain Group that is possibly 1,220 $\pm 67 \mathrm{Ma}$ (Reynolds 1985). If this is correct, the Carrizo Mountain Group is older than rocks of the De Baca rift and must have been deposited in a basin of rather limited extent, perhaps in a northwest-trending graben. Metamorphism must have occurred somewhere to the southwest of the present known extent of the Carrizo Mountain Group, i.e., in Chihuahua, because these rocks have been displaced to the northeast by the Streeruwitz thrust. My unpublished interpretation of a seismic line across Devil Ridge and through two wells that encountered the Carrizo Mountain Group (Texaco State "FV"-1 and Border Exploration State "11"-1) indicates a minimum northeastward displacement, along the Streeruwitz thrust, of about 15 $\mathrm{km}$. Gravity and magnetic interpretation (Wiley, 1970, Figure 13) shows a minimum of about $23 \mathrm{~km}$ of movement on the Streeruwitz thrust.

It seems fair to speculate that much of northeastern Chihuahua could have been involved in the pre-De Baca rift magmatism and sedimentation documented from areas of "older" granites to the north, by the Carrizo Mountain Group and by "older" metagabbro and metagranite at Sierra del Cuervo. Further speculation is that the proposed De Baca rift could have extended across Chihuahua to the edge of the Precambrian North American craton - sedimentary rocks in the southernmost exposures of De Baca rocks (Castner Marble, Allamoore Formation) are evidence for a marine incursion into the rift.

In Chihuahua and Trans-Pecos, Texas, the final Precambrian igneous event was the intrusion of Franklin Mountains igneous rocks, with attendant dynamothermal metamorphism, into "older" granite(s), local metasedimentary units, and unmetamorphosed rocks of the De Baca rift. After batholith emplacement, deformation within the hinterland of the Streeruwitz thrust exposed batholith rocks and the Allamoore Formation to erosion but did not expose Carrizo Mountain Group rocks. The Hazel Formation, derived from the exposed rocks, began to accumulate in a basin margin adjacent to this southern highland (Reid, 1989). Streeruwitz thrusting with attendant cataclastic metamorphism and footwall deformation of the Allamoore and Hazel formations was the culmination of this deformation. 


\section{Early Paleozoic (pre-Mississippian)}

There is little or no evidence of widespread Early Paleozoic tectonism within the area of the Mesozoic Chihuahua trough. The pre-Mississippian Paleozoic rocks of the trough area and along its northern perimeter, in the United States, are the result of widespread cratonic shelf deposition along a passive margin of the North American craton. The basal unit, a transgressive sandstone, reflects an advance, probably in a general northeastern direction, of Cambrian and Ordovician seas onto North America (see Stewart and Suczek, 1977, and Hayes, 1978).

During Middle to Late Ordovician time, the boundary of the Proterozoic North American craton, northeast of the La Babia zone (Figure 3), changed when the Cuyania terrane, a piece of North America, separated from the craton at $c a .450 \mathrm{Ma}$ and eventually was attached to South America (Dickerson and Keller, 1998). After departure of Cuyania, the craton northeast of the La Babia zone, assumed the present day north-northeast trending boundary as defined by James and Henry (1993) and the "final" shape of the southern margin of North America was established. This boundary lies outboard of, and subparallel to the Ouachita front.

Studies of early Paleozoic depositional trends at Minas Plomosas Area (Bridges, 1962) and Cerro Carrizalillo (Reyes-Cortés and Potter, 1987) indicate source areas to the north and northwest; there is no evidence for source areas to the southeast or east (Cuyania). This leads to the interpretation that, southwest of the La Babia zone in Mexico, the Proterozoic boundary between the craton and an ocean (Figure 3) was maintained through the early Paleozoic. This interpretation and the apparent absence of any Ouachita facies rocks southwest of the La Babia zone leads to the conclusion that this zone is a prominent discontinuity between 1) an ocean and Cuyania until Middle Ordovician time, and 2) between late Paleozoic accreted terranes. This implies that the earliest Phanerozoic activity in Trans-Pecos, Texas, and Chihuahua, within the zone of crustal weakness along the southwestern margin of the North American craton, was the departure of Cuyania.

López-Ramos (1969) showed "emerged land" during the early Paleozoic for the area south and southwest of northeastern Chihuahua. This is not in conflict with the interpretations presented here because the "emerged land" of López-Ramos (op. cit.) is included in terranes that accreted to North America subsequent to the early Paleozoic, probably during late Paleozoic time.

Lower Paleozoic formations described in New Mexico and Trans-Pecos, Texas, are readily recognized in wells and can be correlated with formations of the unique Lower Paleozoic outcrop area within the Chihuahua Trough (Minas Plomosas Area/Cerro Carrizalillo). Thickness of Cambrian-Devonian sections within and adjacent to northeastern Chihuahua, with the exception of an anomalously thick Devonian unit in PEMEX Los Chinos-1 (LC-1), is rather uniform (typically around 900 meters) and lithologies are similar.

\subsection{Occurrences}

Lower to mid-Paleozoic rocks are reported from seven wells in and adjacent to northeastern Chihuahua (Table 3) and outcrops of these rocks occur in Mina Plomosas-Cerro Carrizalillo region. Table 3 lists outcrop areas in the United States, adjacent to Chihuahua, of three complete Lower Paleozoic sections: Franklin Mountains (LeMone, 1969), Hueco Mountains (LeMone, 1985) and Sierra Diablo (King, 1965). To the northwest, north and east in Arizona, New Mexico, and Texas, partially eroded sections of pre-Mississippian Paleozoic rocks are present in numerous wells and some outcrops. Significantly, Paleozoic rocks of the Ouachita facies are not recognized southwest of the La Babia zone (Figure 3 ). Many authors have speculated that these rocks extend into Mexico, but nowhere is there a definite "sighting" of them.

Some $300 \mathrm{~km}$ to the west, across extensive Tertiary volcanic rocks of the Sierra Madre Occidental, an incomplete thick $(1,500+\mathrm{m})$ Cambrian, Ordovician and Devonian section, including $943+\mathrm{m}$ of miogeosynclinal Cambrian rocks, is described in the vicinity of Sahuaripa and Arivechi, Sonora (Almazán-Vázquez and Fernández-Aguirre, 1987). The Sonora section is generally regarded to be part of an allochthon displaced from southern California in a southeastward direction (left-lateral), along the Mojave-Sonora megashear during the Late Paleozoic (Caborca-Hermosillo block of Stevens et al., 1992) or Jurassic (many authors).

\subsection{Evidence of uplift, erosion and/or non-deposition and faulting}

At various places in New Mexico and Texas, adjacent to northeastern Chihuahua, many authors interpret stratigraphic relations to indicate non-depositional and/or erosional events during Middle Ordovician, Early Silurian and Late Silurian-Early Devonian times. In the Minas Plomosas area, Chihuahua, Bridges (1962) reported continuous deposition from Cambrian time (inferred) into Middle Devonian time with a late Middle Devonian to early Late Devonian interval of erosion.

The Los Chinos-1 well (LC-1), located in the extreme northwestern part of Chihuahua, found anomalously thick Devonian and Mississippian sections (Thompson III et al., 1978). The Devonian section in the well is much thicker $(\sim 760 \mathrm{~m})$ than sections in nearby parts of Arizona and New Mexico (maximum around $185 \mathrm{~m})$ and the apparent $123 \mathrm{~m}$ Devonian section penetrated in PEMEX Centauro-1 (CEN-1). This well bottomed in Ordovician(?) rocks (Thompson III et al., 1978) and is some 48 kilometers to the southwest of Los Chinos-1. The $746 \mathrm{~m}$ Mississippian section in Los 
Table 3. Lower Paleozoic Sections

\begin{tabular}{|c|c|c|c|c|}
\hline Locality/Well & Age & $\begin{array}{l}\text { Thickness } \\
\text { (meters) }\end{array}$ & Formation(s) & Reference \\
\hline PEMEX Los Chinos-1 & $\begin{array}{l}\text { Devonian } \\
\text { Ordovician } \\
\text { Cambrian }\end{array}$ & $\begin{array}{l}754 \\
924 \\
32\end{array}$ & $\begin{array}{l}\text { Percha, Canutillo } \\
\text { Montoya, Cable Canyon, El Paso } \\
\text { Bliss }\end{array}$ & $\begin{array}{l}\text { PEMEX files, 1973; } \\
\text { Thompson III } \text { et al., } 1978\end{array}$ \\
\hline PEMEX Centauro-1 & $\begin{array}{l}\text { Devonian } \\
\text { Ordovician? }\end{array}$ & $\begin{array}{l}123 \\
317 \text { inc. }\end{array}$ & $\begin{array}{l}\text { Not reported } \\
\text { Not reported }\end{array}$ & Thompson III et al., 1978 \\
\hline Franklin Mountains & $\begin{array}{l}\text { Devonian } \\
\text { Silurian } \\
\text { Ordovician }\end{array}$ & $\begin{array}{l}42-70 \\
183-305 \\
\sim 684\end{array}$ & $\begin{array}{l}\text { Percha, Canutillo } \\
\text { Fusselman } \\
\text { Montoya, El Paso, Bliss }\end{array}$ & LeMone, 1969 \\
\hline Hueco Mountains & $\begin{array}{l}\text { Devonian } \\
\text { Silurian } \\
\text { Ordovician }\end{array}$ & $\begin{array}{l}59 \\
181 \\
640\end{array}$ & $\begin{array}{l}\text { Percha, Canutillo } \\
\text { Fusselman } \\
\text { Montoya, El Paso, Bliss }\end{array}$ & LeMone, 1985 \\
\hline Mobil Dorough-1 & $\begin{array}{l}\text { Devonian } \\
\text { Silurian } \\
\text { Ordovician }\end{array}$ & $\begin{array}{l}52 \\
281 \\
653 \text { inc. }\end{array}$ & $\begin{array}{l}\text { Percha } \\
\text { Fusselman } \\
\text { Montoya,El Paso, Bliss }\end{array}$ & Uphoff, 1978 \\
\hline Humble State Univ. "DW"-1 & $\begin{array}{l}\text { Devonian } \\
\text { Silurian } \\
\text { Ordovician }\end{array}$ & $\begin{array}{l}82 \\
293 \\
521 \text { inc. }\end{array}$ & $\begin{array}{l}\text { Percha } \\
\text { Fusselman } \\
\text { Montoya, El paso, Bliss }\end{array}$ & Uphoff, 1978 \\
\hline Gulf Burner State "B"-1 & $\begin{array}{l}\text { Silurian } \\
\text { Ordovician }\end{array}$ & $\begin{array}{l}395 \\
550\end{array}$ & $\begin{array}{l}\text { Fusselman } \\
\text { El Paso, Bliss }\end{array}$ & $\begin{array}{l}\text { Veldhuis and Keller, 1980; } \\
\text { Pearson, } 1980\end{array}$ \\
\hline $\begin{array}{l}\text { Border Exploration Bask } \\
\text { State " } 9 \text { "-1 }\end{array}$ & $\begin{array}{l}\text { Devonian } \\
\text { Silurian } \\
\text { Ordovician }\end{array}$ & $\begin{array}{l}68 \\
164 \\
385 \text { inc. }\end{array}$ & $\begin{array}{l}\text { Percha, Canutillo } \\
\text { Fusselman } \\
\text { Montoya, El Paso }\end{array}$ & $\begin{array}{l}\text { From logs furnished by } \\
\text { Texaco, } 1998\end{array}$ \\
\hline Sierra Diablo & $\begin{array}{l}\text { Devonian } \\
\text { Silurian } \\
\text { Ordovician }\end{array}$ & $\begin{array}{l}38 \\
91 \\
488\end{array}$ & $\begin{array}{l}\text { No formation assignment } \\
\text { Fusselman } \\
\text { Montoya, El Paso, Bliss }\end{array}$ & King, 1965 \\
\hline PEMEX Ojinaga-1 & $\begin{array}{l}\text { "Dev., } \\
\text { Ordovician, Camb }\end{array}$ & $\begin{array}{l}1,120 \\
\text { brian” }\end{array}$ & No formation assignments & $\begin{array}{l}\text { López-Ramos, 1988; Limón } \\
\text { González, } 1986\end{array}$ \\
\hline Minas Plomosas area & $\begin{array}{l}\text { Dev., Silurian, } \\
\text { L. Ordovician } \\
\text { Ordovician }\end{array}$ & $\begin{array}{l}250 \\
300 \text { inc. }\end{array}$ & $\begin{array}{l}\text { Solis Limestone } \\
\text { Sostenes Formation }\end{array}$ & Bridges, 1964 \\
\hline Cerro Carizalillo & $\begin{array}{l}\text { Dev., Silurian, L. } \\
\text { Ordovician } \\
\text { Ordovician } \\
\text { Cambrian? - } \\
\text { Ordovician? }\end{array}$ & $\begin{array}{l}259 \\
461 \\
205\end{array}$ & $\begin{array}{l}\text { Solis Limestone } \\
\text { Sostenes Formation } \\
\text { Falomir Sandstone }\end{array}$ & Dyer and Reyes C., 1987 \\
\hline Sahuaripa - Arivechi & $\begin{array}{l}\text { Devonian } \\
\text { Ordovician } \\
\text { Cambrian }\end{array}$ & $\begin{array}{l}90 \text { inc. } \\
475 \\
943 \text { inc. }\end{array}$ & $\begin{array}{l}\text { No formation assignment; } \\
\text { faulted } \\
\text { El Santísimo } \\
\text { Milpillas, La Huerta, } \\
\text { El Magallon, La Sata }\end{array}$ & $\begin{array}{l}\text { Almazán-Vásquez and } \\
\text { Fernández- } \\
\text { Aguirre, } 1987\end{array}$ \\
\hline
\end{tabular}

Chinos-1 is considerably thicker than projections to the well of an isopach map by Armstrong and Mamet (1978) in southeastern Arizona $(395 \mathrm{~m})$. Some or all of the thickening of the section in Los Chinos-1 may be structural (the well was drilled on a surface anticline in an area where thrust faults are mapped). If the Devonian and Mississippian sections reflect original sedimentary thickness, the section may indicate an initial stage of development of the late Paleozoic Pedregosa Basin and suggests Devonian activity of a basin-bounding fault(s).

Dyer (1989) suggested that recurrent faulting during the Ordovician is responsible for relationships in the Franklin Mountains, that Kottlowski (1965) described as Precambrian monadnocks surrounded by El Paso Limestone that contains rhyolite-cobble conglomerate. Dyer (op. cit.) speculated that some of the faults remained active throughout the Ordovician and perhaps into the Silurian, resulting in the localization of numerous karst fea- 
tures recognized by several authors in Ordovician and Silurian formations. In the Sierra Diablo, King (1965) described post-Van Horn sandstone, pre-Bliss tilting and local faulting which is possibly Cambrian and/or Early Ordovician. These events may be related to rifting during the departure of Cuyania.

In southern New Mexico, Flower (1958) reported periods of faulting during a long period of erosion from Late Silurian to Early Devonian and most of Middle Devonian time. Minor faulting and uplift and subsidence in New Mexico has been correlated with the Antler orogenic belt (Poole et al., 1967) and Late Devonian epeirogeny in the Permian Basin is inferred to be related to the Antler orogeny (Comer, 1991). Relations other than temporal, between early Paleozoic orogenic events (Taconic, Acadian and Antler) and deformational episodes in the environs of the Chihuahua trough are extremely speculative.

\subsection{Summary}

Except for the postulated departure of Cuyania, early Paleozoic evidence for tectonism is rare to absent in and adjacent to northeastern Chihuahua. Disconformities on the Diablo Platform and in central New Mexico indicate periods of shelf exposure that may reflect tectonism affecting northeastern Chihuahua. The proverbial "future work" may shed light that reveals a rather complex early to mid-Paleozoic history of the region, especially during Silurian and Devonian time.

\section{Late Paleozoic}

Four late Paleozoic tectonic events are documented within and immediately adjacent to northeastern Chihuahua. The first three of these events are also described throughout the Ancestral Rockies (many authors) and were first recognized in the Marathon region of Texas. In the Marathon area three pulses (time periods) of late Paleozoic tectonism were documented by King (1937, 1980):

1) Mississippian-Pennsylvanian deformation in the hinterland of the thrust belt (Meramecian-Atokan with pause during Morrowan).

2) Pennsylvanian orogeny (Desmoinesian - Misourian).

3) Pennsylvanian-Permian folding and thrusting (Virgilian-Early Wolfcampian)

These events were followed by:

4) Permian (Late Wolfcampian - Leonardian- Guadalupian?) erosion/truncation and subsequent tilting.

In the following sections, events documented by surface and subsurface data within and adjacent to the Chihuahua Trough, that occurred in similar times are discussed in detail:

Hueco Mountains-Pre-Hueco Limestone (Wolf- campian). Uplift tilting and erosion equivalent to event 3 and probably event 2 of Marathon region; post-Wolfcampian-pre-Cretaceous folding along a northwesttrending axis, possibly equivalent to event 4 of Marathon region

Sierra Diablo Region-Northern Diablo Platform. Possible antecedent is the Late Mississippian-Early Pennsylvanian platform equivalent to event 1 of Marathon region. Late Pennsylvanian-pre-Hueco Limestone (Wolfcampian) folding and erosion equivalent to event 3 and probably event 2 of Marathon region. Flexing beginning at end of Hueco deposition (Leonardian) which could continue for a long period and is equivalent to event 4 of Marathon region.

Southern Diablo Platform (Surface and subsurface south of Sierra Diablo Region). Probable Middle Pennsylvanian-pre-Hueco Limestone (Wolfcampian) uplift and erosion equivalent to events 2 and 3 of Marathon region. Some clues indicate that there may have been a pre-Middle Pennsylvanian positive area related to rightstepping left-lateral displacements associated with the Texas "zone", possibly equivalent to event 1 of Marathon region.

Marfa Basin. Possible Middle Pennsylvanian uplift and erosion as part of Southern Diablo Platform equivalent to event 2 of Marathon region. Late Pennsylvanian (post-Desmoinesian)-early Wolfcampian basin formation equivalent to event 3 of Marathon region followed by continued development of late Wolfcampian-??? (Ochoan?) basin equivalent to event 4 of Marathon region. sion.

Ojinaga area. Possible pre-Permian uplift and ero-

Placer de Guadalupe-Carrizalillo. Folding and faulting of Placer de Guadalupe area at least partly contemporaneous with deposition of the Plomosas Formation. The only age constraints on the conglomerate units of the formation are that they formed after extrusion of a $270 \pm 30$ Ma rhyolite and prior to Late Jurassic time. Best guess is Leonardian-Guadalupian folding and faulting equivalent to event 4 of Marathon region.

Sierra del Cuervo. Post-Early Permian-pre-Aptian thrusting toward the southeast, possibly mid-Permian and equivalent to event 4 of Marathon region.

Florida-Moyotes uplift. Late Pennsylvanian-early Wolfcampian uplift and erosion equivalent to event 3 and probably event 2 of Marathon region.

Pedregosa Basin. Late Pennsylvanian(?)-Leonardian basin equivalent to events 3 and 4 of Marathon region. Possible antecedents are as old as Devonian and definite indications of a Mississippian basin equivalent to event 1 of Marathon region exist in the northwest part.

\subsection{Hueco Mountains}

Baker (1934) noted that, "The exact structure of the Hueco Mountains is hard to determine because their west 
and southwest flanks are covered largely by alluvium of the Hueco Bolson. It is most probable that there is a broad anticline with a northwest-trending axis at the southeast but much lower in the structure and striking northward farther north." King et al. (1945) presented a generalized structure map that is consistent with the observations of Baker (op. cit.). On the map they show structures on the top of the Helms Formation (Mississippian) and on the top of the lower division of the Hueco Limestone (Permian) with the intent to show structure below and above a pronounced unconformity at the base of the Hueco Limestone. On the structural map, King et al. (op. cit.) showed a northwest to westnorthwest trending anticline in southwestern part of the mountains on both of the surfaces, indicating that the anticline formed at some time after deposition of the Hueco Limestone. Attitudes at the surface confirming the anticline are not shown in the map nor on a photogeologic interpretation by Beard (1983).

Paleozoic rocks generally dip toward the north and progressively older rocks are exposed toward the south. At the southern extremity of the range, Precambrian rocks, similar to the Red Bluff granitic complex of the Franklin Mountains are exposed in Pipeline Valley (LeMone, 1985). A major period of uplift produced an angular unconformity that truncated progressively older formations southward prior to deposition of the Hueco Limestone (Pol, 1985). Stratigraphic studies by LeMone (1985) indicated that the Magdalena Group, in the southern Hueco Mountains, is Morrowan/Atokan and that the Hueco Group is Wolfcampian indicating that uplift and erosion is late Pennsylvanian-earliest Permian. This event has been described as possibly corresponding approximately with the climax of deformation of the Ouachita fold belt in the Marathon region (pulse 3) and coeval with deformation in the Sierra Diablo (King, 1965).

Beard (1985) described a west-northwest trending (N $70^{\circ} \mathrm{W}$ ) anticline in Pipeline Valley through the area of Precambrian outcrops, between outliers of south-dipping Ordovician rocks to the south and north-dipping Ordovician rocks to the north and attributed the fold to Permian deformation. King et al. (1945) showed an east-trending down-to-the-north fault to explain relationships between the outliers and the Hueco Mountains and, on a cross section, show displacement on the fault postdating deposition of the Hueco Limestone. There is no compelling reason to accept the folding hypothesis of Beard (op. cit.).

There is some evidence of uplift to the south of the Hueco Mountains in the present-day Hueco Bolson (see Figure 4 and Table 3). The Humble State University well ("DW"-1 ST DW), located ca. $20 \mathrm{~km}$ south of the Hueco Mountains, found Wolfcampian rocks on Silurian Fusselman Limestone at a drilled depth of 4,733 m (PEMEX files, 1973). This indicates extensive pre-Permian erosion. The Mobil Dorough-1 (DOR), about 20 km southsouthwest of the Hueco Mountains and about $24 \mathrm{~km}$ northwest of the Humble well, found Cretaceous rocks on Mississippian rocks at 1,450 meters (Pearson, 1980). This can be interpreted as representing one or more periods of pre-Cretaceous erosion on an uplift originated during the late Paleozoic.

\subsubsection{Summary}

The simplest interpretation of the southern Hueco Mountains is that there was a period of late Pennsylvanian-earliest Permian uplift that tilted pre-Permian formations toward the north. During the ensuing period of erosion, the basal Permian Powwow Conglomerate member of the Hueco Limestone was deposited in local low areas and, subsequently the Hueco Limestone covered the entire area. At a later time, the fold that constitutes the present structure of the mountains developed. There are no constraints on the minimum age of folding but it is probably pre-Cretaceous

\subsection{Diablo Platform}

The Diablo Platform as shown by King (1942, Figure 18) includes an area extending south-southeast from the New Mexico-Texas border, across the Diablo Plateau through the Sierra Diablo to $30^{\circ} 30^{\prime} \mathrm{N}$. This feature is a southern extension of the Otero platform of New Mexico, which lie along the axis of the Pedernal uplift. The Diablo Platform as defined by King (op. cit.) is bounded on the south and southwest by the Marfa Basin and on the east and northeast by the Delaware Basin. The Hovey Channel connects these basins around the southern tip of the platform. In this paper, Diablo Platform will be discussed in two parts: 1) Sierra Diablo-Northern Diablo Platform (area mapped by King, 1965 and area to the north of Van Horn, Texas), and 2). Southern Diablo Platform (area south of King'sSierra Diablo Region = south of $\left.31^{\circ} \mathrm{N}\right)$.

\subsubsection{Sierra Diablo - Northern Diablo Platform}

King (1965) described late Paleozoic geology of the Sierra Diablo region in detail and there is no need to reiterate many details of his work. His tectonic history includes a late Pennsylvanian deformation of pre-Permian rocks (pre-Hueco Limestone=pre-Late Wolfcampian) into broad anticlines and synclines with local displacement along west-northwest-trending faults and flexures. King et al. (1945.) suggested that this period of deformation and erosion is coeval with events in the Hueco Mountains and may correspond approximately to the climax of deformation in the Ouachita fold belt of the Marathon area (King, 1937). He also described "flexing" along three west-northwest-trending axes (Babb and Victorio flexures and along the South Diablo fault) that culminated some time after deposition of Permian rocks (pre-Cretaceous deposition) but began during Leonard time immediately after deposition of the Hueco Limestone. 


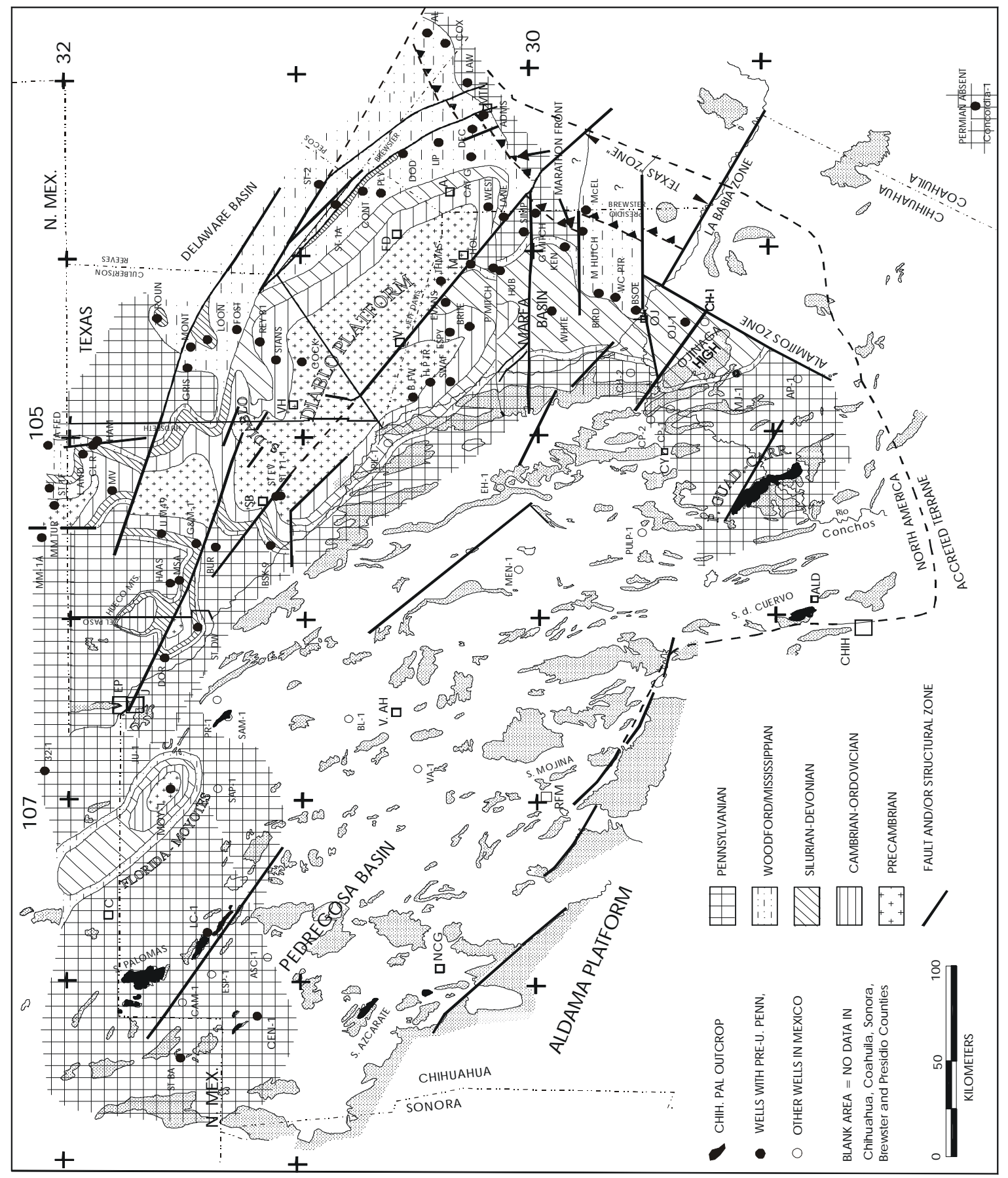


Folds developed during the late Pennsylvanian orogenic event trend east-northeast and plunge toward the northeast. Fold axes form acute angles of 30 to $40^{\circ}$ with west-northwest-trending faults (Figure 4 and King, 1965, Figure 2, p. 44). Overall, pre-Permian (Hueco Limestone) deformation caused the southern part of the Sierra Diablo region to become a positive area (Diablo Platform), and the part to the north a negative area (Delaware Basin) (King, 1965). West-northwest-trending faults and flexures are down-to-the north; King does not describe strike-slip motion on them during the late $\mathrm{Pa}$ leozoic but does present evidence of its activity at that time. He does suggest that Precambrian strike-slip displacements along these faults may have established a "grain" in the region which was utilized during later times of deformation by differently directed forces. King (op. cit.) concluded that strike-slip displacement involving rocks younger than Precambrian cannot be proven on these faults and stated that, in some cases, there is evidence against such a displacement: "Seemingly, then, the forces which caused the subsequent flexing and faulting of the west-northwestward-trending structures were of a different kind and orientation from those of late Precambrian time and were merely guided by the lines of weakness already established."

Post-Hueco Limestone "flexing" is not well constrained. Over most of the Sierra Diablo region, Cretaceous sediments were unconformably deposited on Permian rocks, but, at one place, in the western part of the Sierra Diablo foothills, the Cretaceous lies on the Precambrian Hazel and Allamoore formations (King, 1965). Curiously, Cretaceous rocks are not observed on prePermian Paleozoic units at the surface or postulated in the subsurface on cross sections presented by that author. King (1965, p. 105-106., Plate 1) described the angular discordance (unconformity) between Cretaceous and older rocks as slight but increasing on several westnorthwestward-trending monoclinal flexures (Babb, Victorio and an unnamed flexure along South Diablo fault), where Permian units are bent down to the east-northeast. Development of these flexures culminated at some time after deposition of Permian rocks and prior to deposition of Cretaceous rocks. King (op. cit) believed that the "flexing" began immediately after deposition of the Hueco Limestone, because there is a prominent unconformity at the top of this formation (base Bone Spring Limestone) on the Babb and Victorio flexures. He suggested that this deformation produced a topography that influenced the location of reefs and banks during Leonardian time and recognized that flexing may have continued during deposition of the Leonard Series.

A Precambrian-cored late Paleozoic (pre-Hueco Limestone) uplift, north of the Sierra Diablo region in New Mexico, is extended into Texas (Black, 1976, see Figure 4). This author used the term Otero platform for this region, that is bounded to the west by the Orogrande Basin, straddles the southern extension of the Pedernal landmass and is bounded on the east by the Delaware
Basin. The Hunt McMillen-Turner-1 (MM TUR) encountered Precambrian granite at $556 \mathrm{~m}$ after drilling a Permian Yeso and Abo/Hueco section (Black, 1976). Nine kilometers to the east of the McMillen-Turner well, the Turner State-1F (ST 1F) drilled into Ordovician Montoya rocks after penetrating a similar Permian section (Black, 1976). A cross-section through these wells shows five pre-Hueco-Abo faults forming horsts and grabens along the crest of the uplift (Black, 1976). These faults, with stratigraphic throws of as much as $500 \mathrm{~m}$, are indicated by seismic reflection data and apparently have northerly trends. According to Black (op. cit.) they are not precursors to, nor are they related to Laramide structures (folds and faults) of the Otero platform that generally trend north-northwest. Nutt and O'Neill (1998) postulated a similar set of north-trending pre-Permian faults in the vicinity of the Cornudas Mountains and suggested that these mountains are located near the faulted (some $600 \mathrm{~m}$ down-to-the west) western edge of the Otero platform/Pedernal uplift. They also suggested that Precambrian rocks underlie the Hueco Formation on the uplift.

Wilson (1970), while noting "Granted that the Diablo Platform shows little evidence of a Late MississippianEarly Pennsylvanian existence......," suggested that facies of Late Mississippian and Early Pennsylvanian formations, to the west of the Diablo-Pedernal platform, can be interpreted as evidences of a "well established" Diablo Platform during those times.

\subsubsection{Southern Diablo Platform}

Surface evidence for late Paleozoic uplift and erosion of the southern Diablo Platform is the Wolfcampian Hueco Limestone and the local Powwow Conglomerate, that unconformably overlie rocks of the Precambrian Carrizo Mountain Group in the Eagle, Carrizo, Van Horn and Wylie mountains. The surface data and subsurface data from some 13 wells in Brewster, Culbertson, Jeff Davis, and Presidio counties (Table 3) are interpreted to show a Precambrian-cored Southern Diablo Platform (Figure 4).

Timing of initial uplift of the Southern Diablo Platform is uncertain, complicated by, and inexorably linked to the Marfa Basin. The pre-Upper Pennsylvanian/ Permian subcrop map (Figure 4) suggests an uplifted area, contiguous to the southern Diablo Platform, that extends from the Gulf Hubbard-1 (HUB) to PEMEX Maijoma-1 (MJ-1). If this uplift is coeval with initial formation of the southern Diablo Platform, it indicates premiddle-to-late Pennsylvanian uplift and erosion, because the Cieneguita Formation (Desmoinesian-Missourian, Skinner, 1940), near the Mobil White-1 (WHITE) well, in the Shafter-Chinati Mountains region, was deposited on it. Critical subsurface data for interpretation of this feature are from PEMEX Maijoma-1 (MJ-1), and Ojinaga-1 (OJ-1), Mobil White-1 and, to a lesser degree, Exxon Kennedy-1 (KEN), Gulf Hubbard-1 (HUB) and Mitchell-1 (G MITCH) (Table 2). It should be noted that Ammon (1981) showed Pennsylvanian carbonate rocks 
beneath "Wolfcampian" detrital rocks in the Gulf wells and Pennsylvanian rocks are not present in the Exxon well (Gulf Oil Co., pre-1984, personal communication). Mobil White-1 is the key well for the interpretation of an extended uplift. This well spudded in volcanic rocks about one kilometer west of an east-dipping, northtrending unconformable contact with the mid- to upper Pennsylvanian Cieneguita Formation and apparently encountered Silurian rocks, including the Fusselman Dolomite, intruded by 30 Ma granitic rocks (Mobil Oil Co., personal communication). Available data are sketchy; e.g. "top sil. shale" at $442 \mathrm{~m}$ (sil.: siliceous or Silurian?), "core 875-877 meters, fractured novaculite filled w/ calcite" (Caballos Novaculite or altered tuff ?), "1,2191,371+ m, Silurian and Fusselman". The data are interpreted to indicate absence of Lower Pennsylvanian, Mississippian and Devonian rocks at the well site.

If this interpretation of the southern Diablo Platform has merit, it indicates that this feature predates the Marfa Basin which apparently began to develop during Desmoinesian time and reached maximum development during Wolfcampian and Leonardian time (see Marfa Basin discussion). There are tantalizing clues in the literature to an ancient Diablo Platform. Luff (1981) stated, "It is a distinct possibility that the Sierra Vieja range may have been positive during most of the lower Paleozoic depositional period rather than that these sediments were removed by erosion". Greenlee (1970) described facies within the Silurian-Devonian sequence, as evidence for the southern Diablo Platform defining a "positive" at least as early as Silurian-Devonian time. He further speculated that the southern end of the platform was restructured by the rising and north-northwestward moving Marathon fold belt causing formation of the Hovey channel and Marfa Basin and that the western edge of the Paleozoic Diablo Platform bounds another basin within the Chihuahua trough of Pennsylvanian to Permian age of Delaware Basin proportions (Pedregosa basin of this paper).

\subsection{Marfa Basin}

Information on the Paleozoic history of the Marfa Basin is tenuous because it is based, to a large extent, on unpublished well data and geophysical surveys. Nevertheless, the scraps that can be gleaned from these sources provide important evidences to the course of late Paleozoic history of northeastern Chihuahua.

The Marfa Basin is difficult to define but the concept of a Permian basin "south of the Sierra Diablo and west of the Glass Mountains" (King, 1937) has a long history. King (1948) showed the Marfa Basin as a relatively large basin, south and west of the Diablo Platform, in Texas and Chihuahua. His illustration shows the basin extending at least $80 \mathrm{~km}$ into Chihuahua. Albritton and Smith (1965), in an effort to explain the relationships between Permian rocks in the Malone and Finlay mountains, suggested a narrow Marfa Basin, west of the Diablo Platform, with a southwest boundary near the present position of the Rio Grande, to the west of their report area. To the south, their Marfa Basin extends 30 to $40 \mathrm{kms}$ into Chihuahua. Ammon (1981) limited the Marfa Basin to Texas and used the term Fort Hancock basin for its extension into Mexico and northward along the western edge of the Diablo Platform. DeJong and Addy (1992b) confined their discussion of the Marfa Basin to an area within Texas and described three broad areas within it: 1) "northern shallow Marfa, north of the Walnut Draw fault", 2) "Central Marfa deep bounded by the Chalk Draw and Walnut Draw faults in the south and north respectively", and 3) "southern shallow Marfa south of the Chalk Draw fault". Luff (1981) described the Marfa Basin as ".the area and suite of rocks north of the Ouachita Frontal Zone, south of the Diablo Platform and northeast of the Rio Grande. It is separated from the Delaware Basin to the northeast by the Hovey Anticline. The ancestral Diablo Platform and Van Horn-Sierra Vieja Mountain uplifts form the northern and western limits. To the southwest the Basin grades into the Chihuahua trough".

The Marfa Basin as defined herein (Figures 4 and 5) is the area in Texas bounded on the north by the northernmost (Candelaria structure zone of Dickerson, 1980) of a series of four east-trending faults. Between the Candelaria structure zone and the buried margin of the Marathon thrust belt, the basin is bounded by the Walnut Draw fault. The southern boundary is apparently the southernmost of a series of four east trending "faults" shown in Figure 4 (Tascotal Mesa fault zone), and the southeastern basin boundary is the buried margin of the Marathon thrust belt. The western boundary of the basin is unknown but it can be speculated that it joined a late Paleozoic sea (Pedregosa basin of this paper) that covered the area on northeastern Chihuahua west of the Diablo Platform. The basin is the westernmost of a series of foreland synorogenic basins that formed during the Ouachita-Marathon orogeny, viz. Val Verde, Kerr, Fort Worth and Arkoma basins.

Late Paleozoic rocks crop out in the vicinity of the Chinati Mountains (Shafter, upper Cibolo basin, and Pinto Canyon); published discussions of the Marfa Basin make little or no effort to integrate observations from these outcrops; (e.g., Ammon, 1981; DeJong and Addy, 1992a, 1992b; Luff, 1981; and Pearson, 1981). The remainder of the Marfa Basin is covered by Tertiary formations (about $85 \%$ of basin) and Cretaceous rocks. Definition of the basin is based on well control and geophysical surveys. Data are available from some 20 wells and there is one published seismic time-structure map, constructed from admittedly poor quality seismic data, contoured on the Silurian (DeJong and Addy, 1992b). In the vicinity of the Chinati Mountains, Cieneguita Formation is the oldest and presumably the basal unit of what has been described as "a single uninterrupted depositional unit" (Baker, 1929). Skinner 


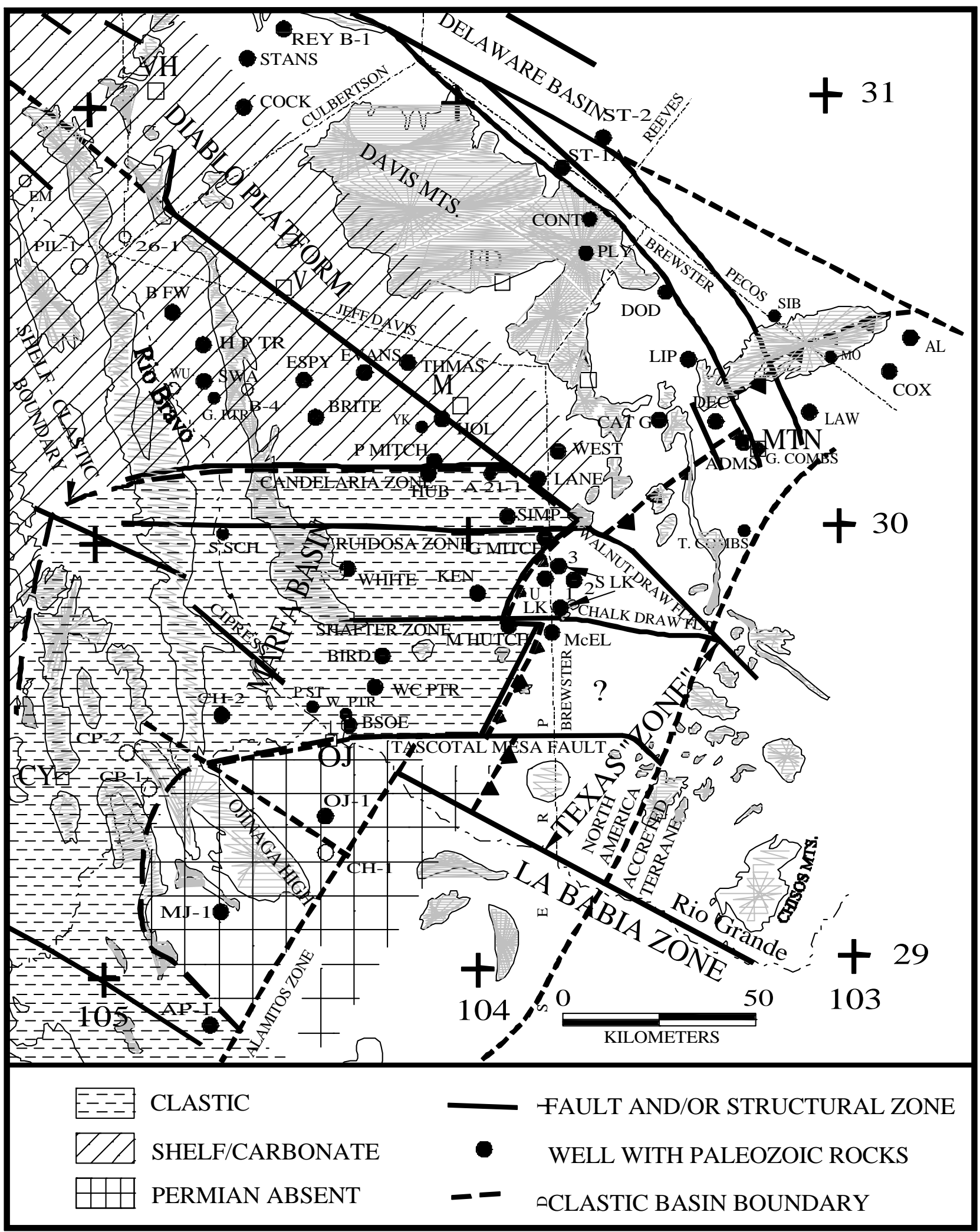

Figure 5. Map of Marfa Basin and environs showing paleogeology (shelf/carbonate, clastic basin and area where Permian is absent) at end Wolfcampian time. Abbreviations for cities and towns same as Figure 1; Well abbreviations from Table 1; Candelaria, Ruidosa and Shafter structural zones from Dickerson (1980); Texas “zone” from Muehlberger (1980). 
(1940) reported Desmoinesian, Missourian and Virgilian fossils from the Cieneguita, no diagnostic fossils from the overlying Alta Formation at the type section, and upper Wolfcampian through Guadalupian fossils from overlying units. Of some interest is the comment by Wilson (1970) that W.B. Saunders and W. Furnish, in a personal communication, reported youngest Chesterian ammonoids in the Chinati Mountains. These forms must be from the Cieneguita Formation and if the Chesterian age is correct, the thoughts presented here require considerable revision.

Subsurface studies in the deeper parts of the basin recognize two points: 1) It is difficult to assign ages to detrital sediments but most of them appear to be Wolfcampian, with the exception of some rocks in the extreme southern part of the basin which may be Pennsylvanian (Ammon, 1981), and 2) a thicker section of Pennsylvanian rocks in the deeper part of the basin suggests that a depression was beginning to form near the end of Pennsylvanian time (Luff, 1981). Atokan rocks, presumably platform carbonates (Gulf Oil Co., pre-1984, personal communication), occur beneath Wolfcampian detrital sediments in the El Paso Simpson1 (SIMP). Ammon (1981) reported Pennsylvanian shelf carbonate rocks in the northern part of the basin and showed Pennsylvanian carbonate rocks in the Gulf Mitchell-1 (G MITCH). The Gulf Mitchell-1 is a deepening of the Argo Mitchell-1 that was abandoned at 3,046 m after drilling into Desmoinesian rocks (Dietrich, 1966). The stratigraphic evidence from the Chinati Mountains indicates that the Marfa Basin began to develop during middle Pennsylvanian (Desmoinesian) time and the basin continually received sediments for the remainder of Pennsylvanian time and throughout the Permian. Ammon (1981) concluded that the principal period of basin development was during Wolfcampian and early Leonardian time, because rocks of these ages comprise some 90 percent of detrital sediments in the basin. He describes Guadalupian and Ochoan detrital rocks from wells in the northern and western parts of the basin. Ross and Ross (1985) suggested that the Marfa Basin developed in two tectonic phases: 1) thrusting of the Marathon allochthon onto a Desmoinesian carbonate shelf on the cratonic margin formed the initial basin that received sediments from the allochthon, and 2) thrusting of the Dugout Creek allochthon, during middle Wolfcampian time, formed a smaller "successor" basin.

\subsubsection{Faulting}

Major late Paleozoic activity of the faults shown by Figures 4 and 5 is interpreted from subsurface data (see Table 4). These data indicate a reversal of apparent movement on at least one east-trending fault, within the Marfa Basin (Figure 6). This suggests an early (preWolfcampian) left-lateral regime along the westnorthwest trending Texas Lineament and La Babia features followed by a right-lateral system during Permian deposition (maximum extent of the basin).
Late Paleozoic down-to-the north faulting with about $3 \mathrm{~km}$ of displacement is demonstrated within the Marfa Basin along the Chalk Draw fault zone (Shafter structure zone of Dickerson, 1980) by relationships between the Exxon Kennedy-1 (KEN) and Amoco Moody-Hutchins1 (M HUTCH) wells (Gulf Oil Co., pre-1984, personal communication; DeJong and Addy, 1992b). Relationships between Pure Lane-1 (LANE) and El Paso Simpson-1 (SIMP) can be interpreted to show around $1.5 \mathrm{~km}$ of late Paleozoic down-to-the south movement on the Walnut Draw fault (well data from Gulf Oil Co., pre1984, personal communication). These relationships lead to the general interpretation that the area between the Chalk Draw and Walnut Draw fault zones was a subsiding graben accumulating a thick section of Pennsylvanian-Permian, particularly Wolfcampian, rocks (DeJong and Addy, 1992b).

Demonstration of Late Paleozoic movement on the two northern east-trending "faults" terminating against the Walnut Draw fault (Figure 5) is more tenuous. The northernmost zone, bounding the Marfa Basin (Candelaria structural zone of Dickerson, 1980), apparently was a down-to-the north fault prior to Permian deposition (reverse fault). During Permian deposition, there may have been a movement reversal (normal fault) along this zone. According to information from Gulf Oil Co. (pre-1984, personal communication) Phillips Mitchell-1 (P MITCH), north of the fault, drilled from Permian rocks into Pennsylvanian limestone at $2,411 \mathrm{~m}$ (-904 m) and Gulf Hubbard-1 (HUB), south of the fault, drilled from Leonardian rocks into Devonian rocks at $2,545 \mathrm{~m}(-1,143 \mathrm{~m})$. Figure 6 shows a Wolfcampian section in this well based on remarks by Pearson (1981): "Lower Permian (Wolfcampian) conglomerates found in the Gulf No. 1 Hubbard well ...may contain minerals indicating a metamorphic source." Absence of Pennsylvanian and Mississippian rocks in the Hubbard well suggest that its site was elevated relative to the Mitchell well prior to commencement of Permian sedimentation (Figure 6). Today, Phillips Mitchell-1 is structurally higher than Gulf Hubbard-1 at the base of the Permian, which suggests a movement reversal along the fault during or subsequent to Permian deposition. Some of this down-to-the south movement must have occurred during the Permian because detrital Permian sediments are apparently confined to the area south of the fault. North of the fault, Permian rocks consist of "shelf carbonate" facies and Wolfcampian rocks are not present or are very thin in several wells (Ammon, 1981; Luff, 1981). Of some note is the absence of Cretaceous rocks in the Hubbard-1 and the presence of a thin Cretaceous section $(40 \mathrm{~m})$ in the Mitchell-1. These wells are on the Early Cretaceous "Marfa Island" described by Pearson (1981) which may be contiguous to a postulated island in the Lower Cretaceous sea in the area of the Glass and Del Norte mountains (King, 1937).

The next east-trending fault to the south (Ruidosa structural zone of Dickerson, 1980) can be interpreted as 
Table 4. Well Data Used to Construct Pre-Upper Pennsylvanian/Permian Subcrop Map.

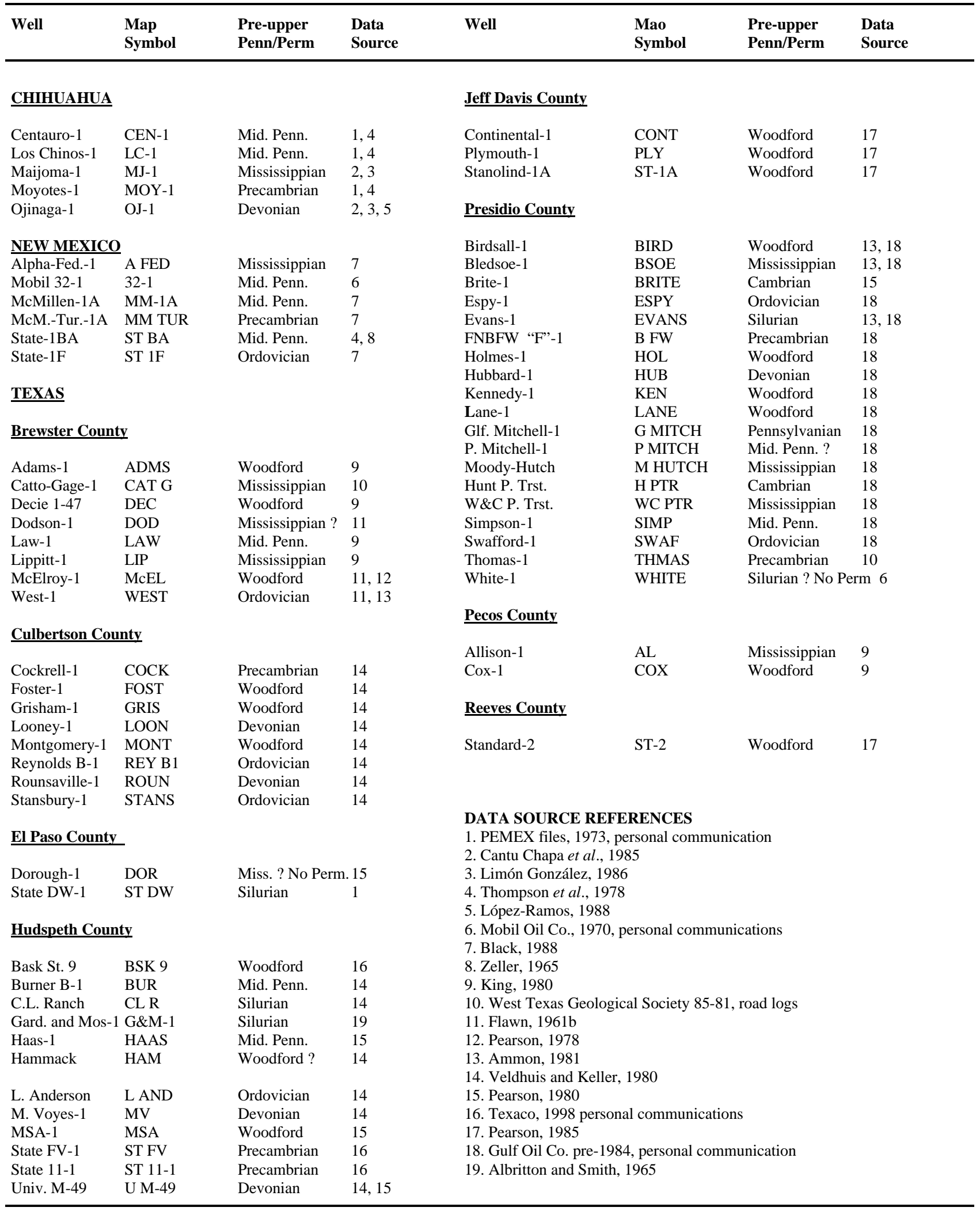




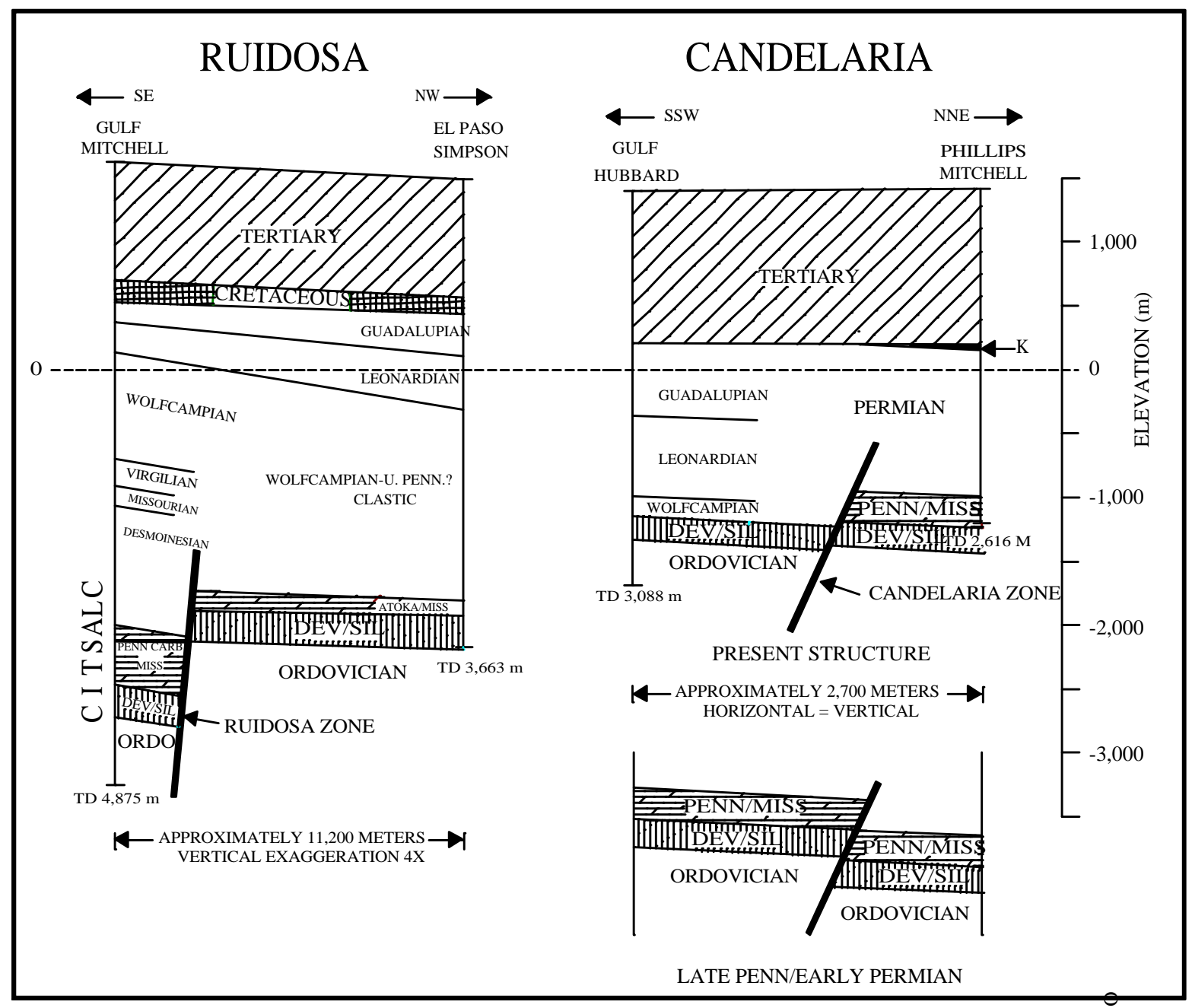

Figure 6. Cross sections showing inferred structure across Ruidosa and Candelaria structural zones of Dickerson (1980). Late PennsylvanianPermian normal faulting is postulated across both zones from well data and initial early late Pennsylvanian/early Permian reverse faulkng is inferred along the Candelaria zone.

active prior to and during deposition of Permian rocks. According to information from Gulf Oil Co., El Paso Simpson-1 (SIMP), north of the fault, drilled from Wolfcampian rocks through $391 \mathrm{~m}$ of Atokan and Mississippian rocks into the Woodford Formation at $3,413 \mathrm{~m}$. Gulf Mitchell-1, south of the fault, drilled at least $805 \mathrm{~m}$ of Pennsylvanian and Mississippian rocks before encountering the Woodford Formation at 4,060 m (Pearson, 1978). The much thicker section of Pennsylvanian and Mississippian rocks on the downthrown side of the fault suggests activity during their deposition (Figure $6)$.

Late Paleozoic history of the southernmost easttrending fault, the Tascotal Mesa fault zone (Presidio structural zone of Dickerson, 1980), is not known. Dickerson (1995) presented a convincing argument for late Paleozoic activity of the Tascotal Mesa fault from subsurface data and analogy with nearby areas. She cited relationships between PEMEX Ojinaga-1 (OJ-1), south of the westward projection of the Tascotal Mesa fault, where Permian through Mississippian rocks are absent and the West Bledsoe-1 (BSOE), north of the fault, which encountered Permian, Pennsylvanian and Woodford as evidence for Late Paleozoic relative down-to-the north movement on the western segment of the fault; this is the interpretation shown in Figure 4. These relationships can also be interpreted to indicate relative down-to-the east movement on a northwestern projection of the La Babia zone (see discussion under "Ojinaga Area") or along a southeastern projection of a herein postulated Late Paleozoic fault (Figure 5) that follows the present Cipress fault (Gries and Haenggi, 1970).

Pearson (1978) interpreted relationships between the Shannon Lykes wells 1, 2 and 3 (S LK 1, 2, and 3), north of the Chalk Draw fault and southwest of the Walnut Draw fault (wells shown in Figure 5), and the Sun McElroy-1 (McEL) as indicating a northwestward bulge or salient of a frontal thrust of the Marathon fold belt in 
the Green Valley area. The Union No. 1 Lykes-State (U LK on Figure 5) also encountered Marathon facies rocks. A considerable thickness (more than 1,120 m) of rocks of the Marathon facies is preserved in a graben between the Chalk Draw Fault and the Walnut Draw Fault. Permian rocks were not encountered by these wells, but Pearson (op. cit.) postulated on a cross section that Wolfcampian rocks are present beneath a thrust in the Shannon wells, indicating that the latest thrusting was sometime during Wolfcampian. Farther south, across the Chalk Draw Fault, the Sun McElroy-1 (McEl) encountered a 370-m thick section of Marathon facies rocks (Fort Pena and Woods Hollow formations overturned) above what is believed to be Pennsylvanian black shale and quartzitic sandstone that in turn overlies a normal cratonal sequence of Woodford, Devonian, Silurian, Ordovician rocks and a "basal Ellenburger sand" that may be Cambrian (Flawn, 1961b). Age of thrusting seems to be Late Pennsylvanian-earliest Wolfcampian. Luff (1981) states that "recent seismic work and well data in the Marfa Basin also indicate that the Ouachita movement provided little or no sediment to the thick Wolfcampian section and played little or no part in forming the structural pattern of the basin" -a strong conflict with the views of other authors (Ammon, 1981; DeJong and Addy, 1992a; Pearson, 1981; Ross and Ross, 1985; this paper), that the Marfa Basin is a direct consequence of Ouachita-Marathon orogenesis.

\subsubsection{Interpretation and Speculations}

Baker (1934) described two belts of approximately east-trending features which cross structures, interrupt, and influence the more general strikes of the Cordilleran orogeny:

1. "A zone which at the east is near the 31 st Parallel and turns beyond Van Horn to the northwest and extends to El Paso". The Texas Lineament of Ransome (1915).

2. "A zone $29^{\circ} 45^{\prime}$ North Latitude which extends from the mouth of Pecos River westward to the south end of the Chinati Mountains near Shafter."

Dickerson (1980) described these features as probable boundary transforms during Tertiary Rio Grande rifting and designates them as the Van Horn and Shafter structural zones. Between these major features there are several east-trending lineaments, e.g. Valentine, Candelaria and Ruidosa structural zones of Dickerson (1980). Dickerson identified and cataloged east-trending structures of apparent lesser magnitude to the north, viz. South Hueco Mountains and North Baylor Mountain zones and to the south, viz. Presidio (Tascotal Mesa fault), Terlingua and Santa Elena zones. Time of origin of all of these features is uncertain but some of their antecedents may be as old as Precambrian (Dickerson, 1980).

As discussed in the previous section, apparent vertical movements on east-trending faults, that can be related to Dickerson's structural zones, are the basic control for development of the Marfa Basin. The basin is within the broad Texas Lineament zone of Muehlberger (1980), whose boundaries are expressed by LANDSAT and space-photo lineaments. The southern limit of the Texas "zone" of Muehlberger (op. cit.) is along the La Babia zone and its projection to the northwest. The northern boundary is a LANDSAT lineament extending from south of the Wylie Mountains, through Marfa, Texas, along the northeastern tip of the Sierra del Carmen and into Coahuila (basically the same feature shown on Figure 4 extending from Sierra Blanca, Texas, immediately southwest of Marfa, along the Walnut draw Fault and joining the southeastern "hook" of the Chalk draw Fault). Right-lateral movement along segments of these northwest-trending zones during latest Pennsylvanian and Permian time could form the Marfa Basin as a pullapart basin (releasing sidestep) between right-stepping systems of the Texas "zone" of Muehlberger (op. cit.).

The postulated earliest movements on the Candelaria zone, an east-trending fault bounding the Marfa Basin, with opposite vertical sense of motion to that interpreted during basin formation, is puzzling. These early movements resulted from an early pulse of left-lateral movement along segments of the Texas Lineament zone that produced reverse faults in a restraining sidestep. In this scenario, the Southern Diablo Platform and the Ojinaga area (see next section) would form a pop-up structure exposed to pre-Permian erosion.

Support for the existence of fairly widespread leftlateral regimes along the Texas Lineament zone is the interpretation of Beck and Chapin (1991) of a left-lateral Late Paleozoic wrench zone encompassing the Orogrande and Lucero basins in New Mexico, and the interpretation of Hills (1970) of late Paleozoic structural directions in the southern Permian Basin. Beck and Chapin (op. cit.) extrapolated data from a small area (Joyita uplift) to a postulated north-trending shear zone which affected rocks as young as the Bursum Formation (early Wolfcampian) and controlled development of the Orogrande, San Mateo and Lucero basins. Hills (op. cit.) presented an argument for Early Permian left-lateral motion on a $\mathrm{N} 60^{\circ} \mathrm{W}$-trending fault (Pecos Valley fault) on the Central Basin Platform, and suggested left-lateral movement along a deep-seated zone along this trend, related to the Babb and Victorio flexures. According to Hills (op. cit.), two tectonic systems are present. Leftlateral faulting activity had its inception during latest Mississippian time, continued intermittently throughout Pennsylvanian time and preceded activity on a rightlateral fault system trending slightly west of north (e.g., West Platform fault). Somewhat in contrast, Yang and Dorobek (1995) imply late Pennsylvanian-Wolfcampian left-lateral displacement on a west-northwest-trending fault separating the Central Basin Platform into two structural blocks (Andector and Fort Stockton blocks) and on west-trending faults in the Delaware Basin (Grisham fault) and Midland Basin (Big Lake fault). They interpret the left-lateral displacements as the consequence of right-lateral motion on fault systems bounding 
the Central Basin Platform and causing clockwise rotation of the platform structural blocks.

Paleogeographic, structural, and sedimentary history of the Marfa Basin indicates a middle Pennsylvanian (Atokan/Desmoinesian) period of left-lateral motion on segments of the Texas "zone" of Muehlberger (1980) with resultant pop-up and erosion of southern Diablo Platform and possibly of the Ojinaga area. The easttrending faults of the area may have had their inception as reverse and/or strike-slip faults during this episode. Post-Desmoinesian through Permian right-lateral motion on right-stepping faults of the Texas Lineament zone caused reversal of sense of motion on pre-existing easttrending faults and development of a pull-apart basin, the Marfa Basin.

\subsection{Ojinaga Area}

Data from Limón González (1986) and López-Ramos (1988) indicates post-Pennsylvanian-pre-Late Jurassic uplift and erosion south and southwest of Ojinaga in the extreme southeastern corner of the Chihuahua trough. After passing through a Cretaceous section, including a relatively thin basal unit $(100 \mathrm{~m}$ "equivalent Las Vigas"), to a depth of 2,800 m, PEMEX Ojinaga-1 (OJ-1) penetrated 1,120 m of Devonian, Ordovician, and Cambrian sedimentary rocks before encountering Precambrian granite at $3,920 \mathrm{~m}$. After penetrating a nearly complete Cretaceous section and a very thin (about $30 \mathrm{~m}$ ) Upper Jurassic unit (La Casita Formation), PEMEX Maijoma-1 (MJ-1), located about $37 \mathrm{~km}$ southwest of Ojinaga-1, encountered about $230 \mathrm{~m}$ of Pennsylvanian and Mississippian carbonate rocks before abandonment. PEMEX Apache-1 (AP-1), located about $30 \mathrm{~km}$ slightly west of south from Maijoma-1, found $630 \mathrm{~m}$ of Permian rocks below thick $(4,890 \mathrm{~m})$, nearly complete Cretaceous and Jurassic sections. Limón González (op. cit) and López-Ramos (op. cit) interpreted relationships between these wells to indicate development of the Mesozoic Chihuahua trough along the flank of an eroded uplift, but they do not speculate on late Paleozoic tectonism in the area. It should be noted that Limón-González (op. cit) and López-Ramos (op. cit) interpreted the evaporite/ clastic sequences penetrated by PEMEX wells Cuchillo Parado-1 (CP-1) and 2 (CP-2), located 35 to $50 \mathrm{~km}$ north-northwest of Maijoma-1, as Permian, whereas this paper, Cantu-Chapa et al., (1985), Gries, (1970), Haenggi, (1966), Hennings, (1991), Navarro-G. and Tovar-R., (1974) consider the Cuchillo Parado "evaporite" section to be Jurassic.

There is little doubt that there has been some uplift and erosion in the Ojinaga-1 - Maijoma-1 region, but timing and extent are uncertain. If Permian rocks were never present, several periods of uplift are possible, but there must have been significant tectonism to construct a positive area during late Pennsylvanian and Permian time. Alternatively, if Permian rocks were present and conformable with earlier Paleozoic rocks, uplift and erosion must have been post-Permian deposition-pre-Late Jurassic. Finally (based on the proverbial "regional considerations"), it can be argued that late Pennsylvanianearliest Permian uplift and erosion were followed by Permian deposition and that subsequent reactivation of the uplift caused the Permian rocks to be stripped from the region.

West Bledsoe-1 (BSOE) in Presidio County, Texas, about $23 \mathrm{~km}$ north $15^{\circ}$ east of Ojinaga-1, penetrated $620 \mathrm{~m}$ of Permian (Wolfcampian) rocks and $899 \mathrm{~m}$ of "Pennsylvanian shale" overlying the Woodford Formation and "Devonian/Silurian" (Gulf Oil Co., pre-1984, personal communication). This well is located northeast of the La Babia zone, north of the westward projection of the Tascotal Mesa fault zone, and is separated by these features from Ojinaga-1 (see Figure 5). Several other wells in Presidio County also penetrated Permian and Pennsylvanian rocks. Fairway Birdsall-1 (BIRD) encountered at least $478 \mathrm{~m}$ of Wolfcampian sediments, $417 \mathrm{~m}$ of igneous rocks, then Woodford (MississippianDevonian) and older Paleozoic rocks (Ammon, 1981). West Presidio Trust-1 (W PTR) penetrated $430 \mathrm{~m}$ of the Alta Formation (Wolfcampian) without reaching its base (Gulf Oil Co., pre-1984, personal communication). West and Cockburn Presidio Trust-1 (WC PTR) found $963 \mathrm{~m}$ of Permian rocks on "pre-Pennsylvanian" shale that is probably Mississippian (Gulf Oil Co., pre-1984, personal communication; Ammon, 1981). In addition to the wells in Texas, PEMEX Chapo-2 (CH-2), located about $37 \mathrm{~km}$ northwest of Ojinaga-1, apparently bottomed in Permian rocks (PEMEX files, 1973; Díaz, 1964). Perhaps significantly, all of the wells that penetrated late Paleozoic rocks are north of the Tascotal Mesa fault zone or its projection into Chihuahua.

There is nothing in the data to preclude late Pennsylvanian-earliest Wolfcampian uplift followed by subsidence and deposition of Permian sediments in the Ojinaga-1-Maijoma-1 area, nor are there data that supports extension of a Permian basin into the area; any interpretation is a speculation. Speculations about the tectonics of this area must incorporate an interpretation of the fate of the Marathon thrust belt which may 1) terminate against the La Babia zone (Figures 4 and 5); 2) continue on a general west-southwest-trend into Chihuahua, south of the "Ojinaga Area" (Flawn, 1961a, Bridges, 1962); or 3) swing south from the "Ojinaga Area" into Chihuahua and Coahuila (Handschy et al., 1987, Keller and Dyer, 1989).

\subsection{Placer de Guadalupe - Carrizalillo}

On the Plomosas uplift (Placer de Guadalupe-Mina Plomosas-Carrizalillo region), post middle Wolfcampian-pre-Late Jurassic tectonism is evident from observed field relationships (Bridges, 1962; Dyer and Reyes, 1987; Roberts, 1989). Timing, including number 
of orogenic periods, and nature and intensity of deformational events during this time span are not clear. Relationships, if any, to the Ouachita structural belt are tenuous. Ouachita tectonism in the Marathon region culminated near the end of Early Wolfcampian time (King, 1978), whereas deformation at the Plomosas uplift did not commence until Middle Wolfcampian time (Bridges, 1962). If there is a relation between tectonic events in this part of Chihuahua and Ouachita orogenesis, Ouachita deformation is significantly younger at the Plomosas uplift than in the Marathon area.

Bridges (1962) interpreted thickness variation of conglomerate, rapid facies changes and angular unconformities within the upper part of the Plomosas Formation (his "Unit 5"; Figure 7), to indicate major tectonic activity during deposition of the unit. The Plomosas Formation is generally considered to be Permian but could range from Permian to Triassic (Bridges, 1964). Below the conglomerate, Wolfcampian and possible Leonardian fusulinids occur in the Plomosas Formation; datable fossils were not found in or above the conglomerate (Bridges, 1962). Extrusive rhyolite below the conglomerate is Leonardian/Guadalupian (270 $\pm 30 \mathrm{Ma}, \mathrm{Pb}$-alpha, de Cserna et al., 1968). In some places, the conglomerate contains more than $80 \%$ fragments of this rhyolite (Bridges, 1962). From imbrication of cobbles in the conglomerate at three localities, and one observation of small-scale cross bedding, Bridges (op. cit.) postulated source areas to the north and northeast.

From field observations and paleontological data, Bridges (1962) determined that tectonism began around middle Wolfcampian time, continued into Leonardian and possibly into Guadalupian time. He attempted to establish a Permian structural trend by restoring preLaramide structure and suggests a "tenuous" northeastsouthwest axial direction, somewhat consistent with postulated Ouachita structural trends.

Bridges (1962) interpreted the major folding and thrusting observed in the Mina Plomosas-Placer de Guadalupe area as Laramide. De Cserna (1965) "differing radically with Bridges", recognized two periods of intense deformation in Paleozoic sedimentary rocks in the "Sierra de Plomosas": 1) early Permian thrusting from the north-northeast toward the south-southwest = "Marathon Orogeny", and 2) late Permian or early Triassic east-toward-west thrusting = Coahuilan Orogeny. He stated that both periods "produced very intense structures such as overturned folds and overthrusts". De Cserna (op. cit.) also described a third deformation, postLate Jurassic/Early Cretaceous ("early Tertiary" Hidalgoan/Laramide) that resulted in relatively minor folding.

De Cserna (1965) stated that the pre patch reef ("Unit 5d", Bridges, 1962, Plate 1) Paleozoic sequence "clearly shows two periods of very intense deformation" while "Unit 5d" and younger rocks "show only the traces of one intense deformation." The interpretation of de Cserna (op. cit.) of the first "intense" deformation is apparently based on his interpretation that the patch reefs in the Plomosas Formation grew on an irregular topography developed on a pre-existing overturned and overthrust structure. Bridges (1962) map shows curious relationships along the western edge of Cerro en Medio that can be interpreted to indicate folding prior to Plomosas deposition or synchronous with early Plomosas deposition (see Figure 7 for location). This relationship is an essentially unfaulted contact between the Plomosas and older Paleozoic units (Bridges (op. cit.) shows a thrust along part of the contact) that shows a strike divergence of up to $80^{\circ}$ between older rocks and the Plomosas -a pronounced angular unconformity, if not caused by an unmapped structure.

According to Bridges (1962), age of the reefs in the Plomosas is late Wolfcampian to early Leonardian. Montgomery (1987) interpreted the patch reefs as allochthonous blocks that have no apparent in situ sedimentary relationship with enclosing clastic rocks, and suggested Leonardian tectonic adjustments dislodged them from a reef along a by-pass margin. If this is accepted, the basis for the first of the intense deformations of Paleozoic rocks of de Cserna (1965) is no longer valid.

Ward (1977) described evidence for one folding event that affects pre-Jurassic rocks and three folding events that affect Paleozoic and Mesozoic rocks. Based on regional considerations, he suggested that preJurassic deformation consisted of uplift beginning in the early Permian followed by deformation before the middle Triassic. He restored an angular unconformity near the mouth of Cañon Monillas (see Figure 7 for location), between the Pastor Limestone (PennsylvanianWolfcampian) and the La Casita Formation (entire Plomosas Formation missing), to the pre-Jurassic attitude, and suggested that this might indicate a northeast strike for the Pastor prior to subsequent deformation(s). Ward (op. cit.) was unable to place the three events affecting Paleozoic and Jurassic rocks in a tectonic sequence, but suggests that Laramide northeast-directed shortening was followed by periods of east- and southeast-directed shortening.

Roberts (1989) recognized pre-Jurassic deformation in the Cerro Los Panales area, about $10 \mathrm{~km}$ southwest of Cerro Carrizalillo. He described a 10 to $30^{\circ}$ angular unconformity between Permian rocks (Plomosas Formation) and Jurassic rocks (La Casita Formation) and attributed low-grade metamorphism of the Plomosas to local thermal events during deformation. Roberts (op. cit.) restored pre-Jurassic attitudes of the Plomosas Formation to obtain dips of 10 to $30^{\circ}$ north-northwest and suggests that this indicates compression in a southeastnorthwest direction. At Cerro Carrizalillo, Dyer and Reyes (1987) described a basement-cored uplift, involving Precambrian rocks, which has been thrusted to the west over upper Paleozoic basinal rocks (Plomosas Formation) and stated that it is not clear whether the thrusting and associated deformation are due to the late Paleozoic Ouachita orogeny or to Late Cretaceous-Eocene Laramide deformation. 
Hennings (1994) modeled the Plomosas uplift as a southwest-vergent fault bend fold, placing Precambrian through Lower Cretaceous units in thrust contact with Lower Cretaceous rocks. He inferred a major hidden detachment, the "Solis thrust", as the principal structure of the Plomosas uplift. Structural relief in the model of Hennings (op. cit.) is about six kilometers, and southwest-directed displacement along the "Solis thrust" ex- ceeds eight kilometers. Hennings (op. cit.) does not describe late Paleozoic tectonism and regards development of the Plomosas uplift as a Laramide event.

\subsubsection{Interpretation}

The simplest interpretation of the structure of the Plomosas uplift involves: 1) development of a late Paleozoic fold (northwest-trending?) associated with a rhyoli-

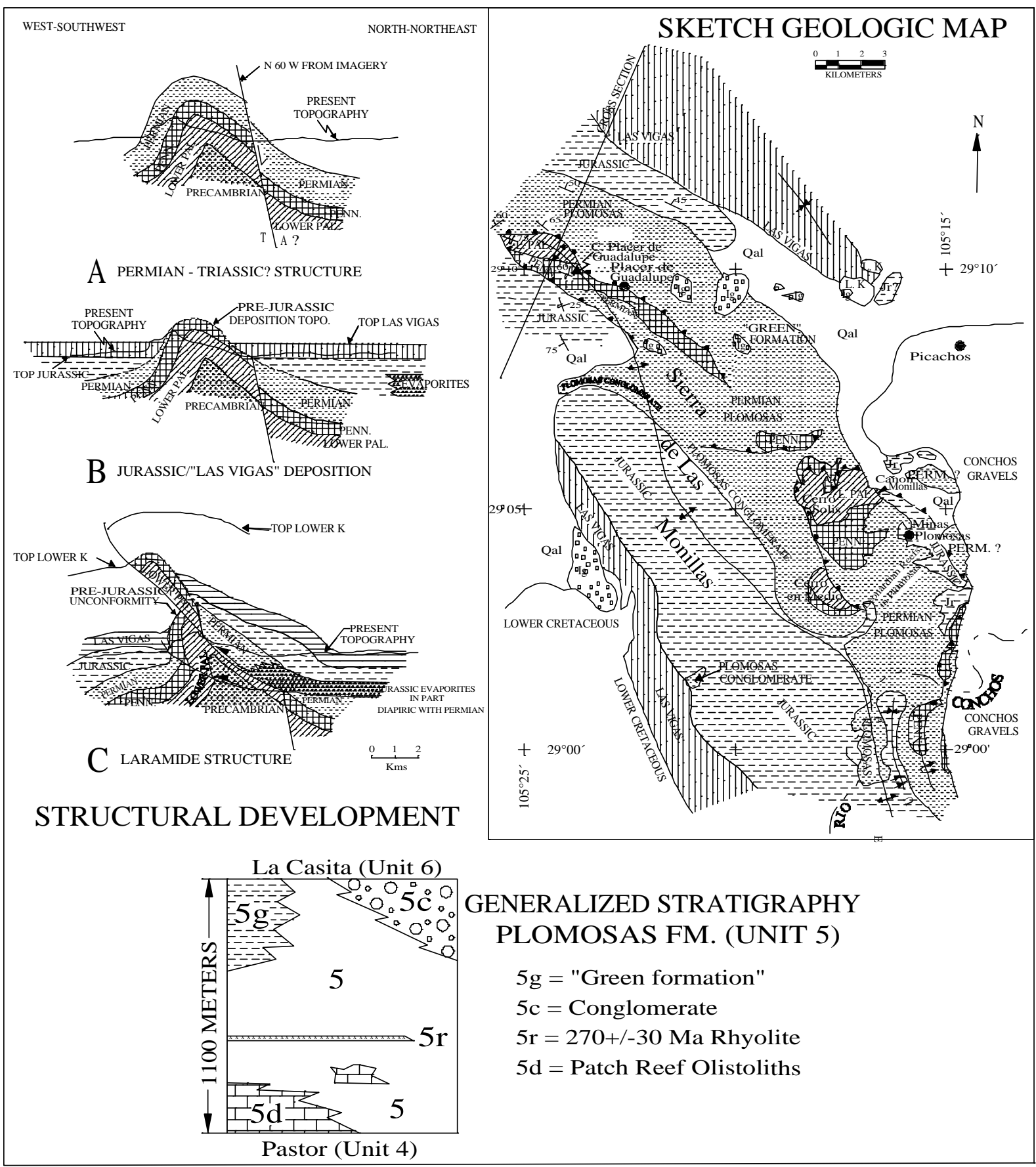

Figure 7. Placer de Guadalupe region. Sketch geologic map (after Bridges, 1964) with long anticline in Sierra de Las Monillas from Hennings (1991). Section showing generalized stratigraphy of Plomosas Formation (Bridges, 1962; 1964). A-C:Sections showing sequential development of structure. Further discussion in text. 
tic volcanic structure and/or a major fault (left-lateral strike-slip) trending approximately $\mathrm{N} 60^{\circ} \mathrm{W}, 2$ ) a long period of erosion until transgression of the Late Jurassic ocean and burial of the uplift during Cretaceous time, and 3) folding and thrusting during the Laramide orogeny. The cross sections on Figure 7 show a postulated sequence for the structural development from Permian through Cretaceous time for the northern end of the Plomosas uplift. The cross section is through Cerro Placer de Guadalupe along the line of a section presented by Bridges (1964) and is in an equivalent structural position to sections to the southeast by Bridges (1962) and Hennings (1994).

Figure 7A shows structure at the end of PermianTriassic(?) deformation. The major fault along the northeast flank of the fold is interpreted from studies of Space Shuttle and satellite imagery and review of available topographic and geologic maps. Hennings (1994) described this feature as a left-lateral "Plomosas basement shear zone" which separates two Laramide allochthons of opposing vergence, but he did not discuss Paleozoic activity along the zone.

Evidence used here for Paleozoic folding is similar to teh argument of Bridges (1962) for Permian deformation. Conglomerate thickness and facies in the upper part of Unit 5 (Permian-Triassic? Plomosas Formation, see Figure 7) shows evidence of major Leonardian and possibly younger tectonic activity during deposition of the unit. Permian $(270 \pm 30 \mathrm{Ma})$ rhyolite, below conglomerate in the Plomosas Formation, can be interpreted to result from magmas emplaced along a basement shear zone that was active during deformation and uplift. Abundant rhyolite clasts in Plomosas Formation conglomerate in the Placer de GuadalupeMinas Plomosas area (rhyolite conglomerate is not present in the Plomosas Formation in the Cerro Carrizalillo area) suggest active erosion of a rhyolite terrain during uplift and folding.

It is not possible to accurately date the numerous thrust faults and folds that Bridges (1962) mapped within Paleozoic units in the Minas Plomosas area. If the interpretation of Montgomery (1987) that Permian patch reefs are allochthonous blocks emplaced during Leonardian time is accepted, thrust faults mapped by Bridges (op. cit.) at the base of the reefs are probably late Paleozoic gravitational structures. Folds and thrust faults involving only Paleozoic rocks could be: 1) related to the postulated Paleozoic folding episode; 2) gravitational features developed during a post-folding period of erosion, e.g., flaps, cascades and slip sheets similar to those described by Harrison and Falcon (1936); or 3) Laramide structures. Obviously these structures could have developed by some combination of Paleozoic folding, gravitational tectonics and Laramide deformation.

It is herein postulated that the Paleozoic Plomosas uplift is a northwest-trending anticline developed during Leonardian and possibly Guadalupian time as a conse- quence of strike-slip (left-lateral displacement) accompanied by rhyolitic volcanism, along a west-northwesttrending basement shear zone. This zone is part of the pervasive system of shear zones which have been postulated to exist in northern Mexico, Arizona, New Mexico and west Texas, e.g., La Babia and San Marcos faults (Charleston, 1981), northwest-trending complex faults in Arizona (Drewes, 1981), and the Texas "zone" (Muehlberger, 1980). Finally. It should be noted that late Paleozoic thrusting toward the east-southeast in the Sierra del Cuervo, near Aldama (Handschy and Dyer, 1987) is not inconsistent with the postulated left-lateral motion of the Plomosas uplift.

Figure 7B depicts postulated pre-Jurassic depositional topography developed on the Paleozoic Plomosas uplift and shows an emergent area on the northwestern part of the uplift during deposition of Upper Jurassic sediment. In the vicinity of Minas Plomosas, stratigraphic relationships between Jurassic and older rocks support the existence of an island and thus, by inference, support the development of a Placer de GuadalupeMinas Plomosas-Carrizallilo anticlinal structure during the Late Paleozoic. Southwest and south of the Mina Plomosas mine, Bridges (1962) mapped overstep of Jurassic strata onto a patch reef ("Unit 5d") of the Plomosas Formation. Locally, the basal Jurassic unit is a conglomerate that is up to $150 \mathrm{~m}$ thick and is largely derived from the underlying reef. The basal contact is very irregular indicating considerable topographic relief. Bridges (1962) suggested that this contact might be an angular unconformity. Near the mouth of Cañon Monillas Ward (1977) and Bridges (1962) showed Jurassic rocks unconformably overlying the PennsylvanianWolfcampian Pastor Formation which further supports the hypothesis presented here.

\subsection{Sierra del Cuervo}

Significance of pre-Cretaceous, slightly metamorphosed, tightly folded sedimentary rocks in Sierra del Cuervo, near Aldama (about $30 \mathrm{~km}$ northeast of Cd. Chihuahua) has been debated over the past 40 years. These rocks, originally described as the Rara Formation by Ramírez-M. and Acevedo-C. (1957), consist of an unknown thickness of a "flysch like" sequence of sandstone, shale and minor carbonate rocks. Thickness estimates range from 1,200 $\mathrm{m}$ (Mellor and Breyer, 1981) to more than 2,600 $\mathrm{m}$ (Villa Aldama formation of LópezRamos, 1969), but structural complication and lack of exposure of the base of the unit make these estimates speculative. Ramírez-M. and Acevedo-C. (op. cit.) reported a measured section of 3,681.5 m but their section apparently crosses one or more thrust faults that were not recognized.

In a comprehensive paper, accepted here as the definitive work on the geology of the Sierra del Cuervo, Handschy and Dyer (1987) concluded that the Rara For- 
mation is an upper Pennsylvanian-lower Permian unit deposited in outer-middle and distal parts of a submarine fan (fan head to the west). Their argument is based on abundant Bouma sequences, coarsening-upward megacycles, and bed geometry. Current lineations, flute casts, channel axes, and ripple cross-lamination indicate that paleocurrents were from the west-southwest in contrast to Mellor and Breyer (1981) who inferred a northern source area, based on framework grain mineralogy. Handschy and Dyer suggested that compositional variations within the Rara Formation indicate that it is derived from unroofing of a basement block to the west. There is no definitive data for the existence of lower- to middlePaleozoic rocks in their postulated source area or, for that matter, at Sierra del Cuervo. There are a few suggestions of volcanic activity during deposition of the Rara Formation; Ramírez-M. and Acevedo-C. (1957) mentioned a 6-meter tuffaceous agglomerate in the upper third of their 3,681.5-meters measured section along Arroyo Juan de Dios ("Unit 20") and Handschy and Dyer (1987) described several thin layers of altered bentonite north of Los Filtros and suggested, after petrographic examination, that they are probably altered volcanic ash. Ramírez-M. and Acevedo-C. (op. cit.) also described a 6-meter conglomerate, near the top of the Arroyo Juan de Dios measured section that contains "igneous material" but did not elaborate ("Unit 8").

Handschy and Dyer (1987) described thrusting involving Precambrian basement and Paleozoic sedimentary rocks (Rara Formation) in Sierra del Cuervo. Stratigraphic relationships restrict the age of this deformation to post-early Permian (post-Wolcampian) and pre-Cretaceous (pre-Aptian). They suggested that regional considerations indicate this deformation occurred during the middle Permian and postulate that it is related to Ancestral Rocky Mountain deformation in the foreland of the Ouachita-Marathon tectonic belt. They did not recognize a large, post-Albian (Laramide), overturned anticline postulated by Mellor and Breyer (1981).

Handschy and Dyer (1987) showed a series of northnortheast striking thrust faults as the predominant structures in Sierra del Cuervo. These faults dip between 0 and $35^{\circ}$ toward the west and place Precambrian rocks on the Rara Formation or are entirely within the Rara Formation. Analysis of numerous folds within and beneath major thrust sheets, indicated predominantly dip-slip movement and a tectonic transport direction of $\mathrm{S} 70^{\circ} \mathrm{E}$. Down-dip fold-axis reorientation beneath major thrust faults, and slickensides on east-striking oblique-slip faults support tectonic transport toward the east.

\subsubsection{Interpretation}

Late Paleozoic structural trends of the Sierra del Cuervo do not agree with Ouachita-Marathon directions nor do they agree with any previously recognized or postulated Paleozoic trends described in northeastern Chihuahua and adjacent areas. They are, however, not inconsistent with left-lateral wrenching along the west- northwest fault zone bounding the Plomosas Uplift which is discussed in the "Placer de GuadalupeCarrizalillo" section of this work. There is little to add to the interpretations of Handschy and Dyer (1987) other than to speculate that their postulated latest Pennsylvanian and early Permian basement-cored uplift west of the Sierra del Cuervo is not part of the North American craton as defined by lead isotope data (James and Henry, 1993) but is part of a late Paleozoic accreted terrane (see Figure 4). Recent lead isotope studies in the Chihuahua portion of the Sierra Madre Occidental, west and northwest of Chihuahua City support this conclusion and indicate the area is underlain by "Coahuilan" basement (McDowell et al., 1999).

The anomalous structures of Sierra del Cuervo and deposition of the Rara Formation flysch (as well as other flysch deposits in the Pedregosa Basin; e.g., PEMEX Villa Ahumada-1 (VA-1) and area west of Nuevo Casas Grandes (see Figures 4 and 8), could be the result of a late Paleozoic collision between North America and an accreted continental block.

\subsection{Florida - Moyotes Uplift}

PEMEX Moyotes-1, about $48 \mathrm{~km}$ south-southwest of Cd. Juárez, penetrated a Permian sequence consisting of Yeso Formation, Hueco Limestone? and Abo Formation on Precambrian granite at a drilled depth of $4,810 \mathrm{~m}$ (PEMEX files, 1973). This is generally believed to indicate that intermittent periods of late Pennsylvanian-Early Permian uplift and erosion caused removal of prePermian rocks from the area around the well. Several authors show this as a separate positive area (Greenwood et al., 1977; Navarro-G. and Tovar-R., 1974) while others show it contiguous to the Florida islands in New Mexico (Thompson III et al., 1978; Wilson, 1987a).

Details of the Florida uplift/Florida islands are scant. Stratigraphic evidence indicates that absence of the Pennsylvanian Series on the Florida uplift is caused by erosion of lower and middle Pennsylvanian rocks off a late Pennsylvanian-Early Permian positive area. This scenario is best depicted by abrupt truncation of lower/ middle Pennsylvanian isopachs against the uplift (Wilson, 1987a). In any event in the vicinity of the Florida Mountains, the postulated uplift was relatively mild. Kottlowski (1958) described the Pennsylvanian history of a "triangular area" from the Robledo Mountains to Cookes Peak and to the Tres Hermanas Mountains, which includes the Florida Mountains as; "The entire triangular area .....seems to have been a low land mass with a few shallow lagoons during Morrowan and Derryan time, perched above the surrounding shallow seas. Relief was somewhat more pronounced in the "triangle" during Desmoinesian and Missourian time with the highest islands probably near the southwest of the Cookes Range. These Mid-Pennsylvanian Florida islands were ringed by the marine shelf seas, ....... The 


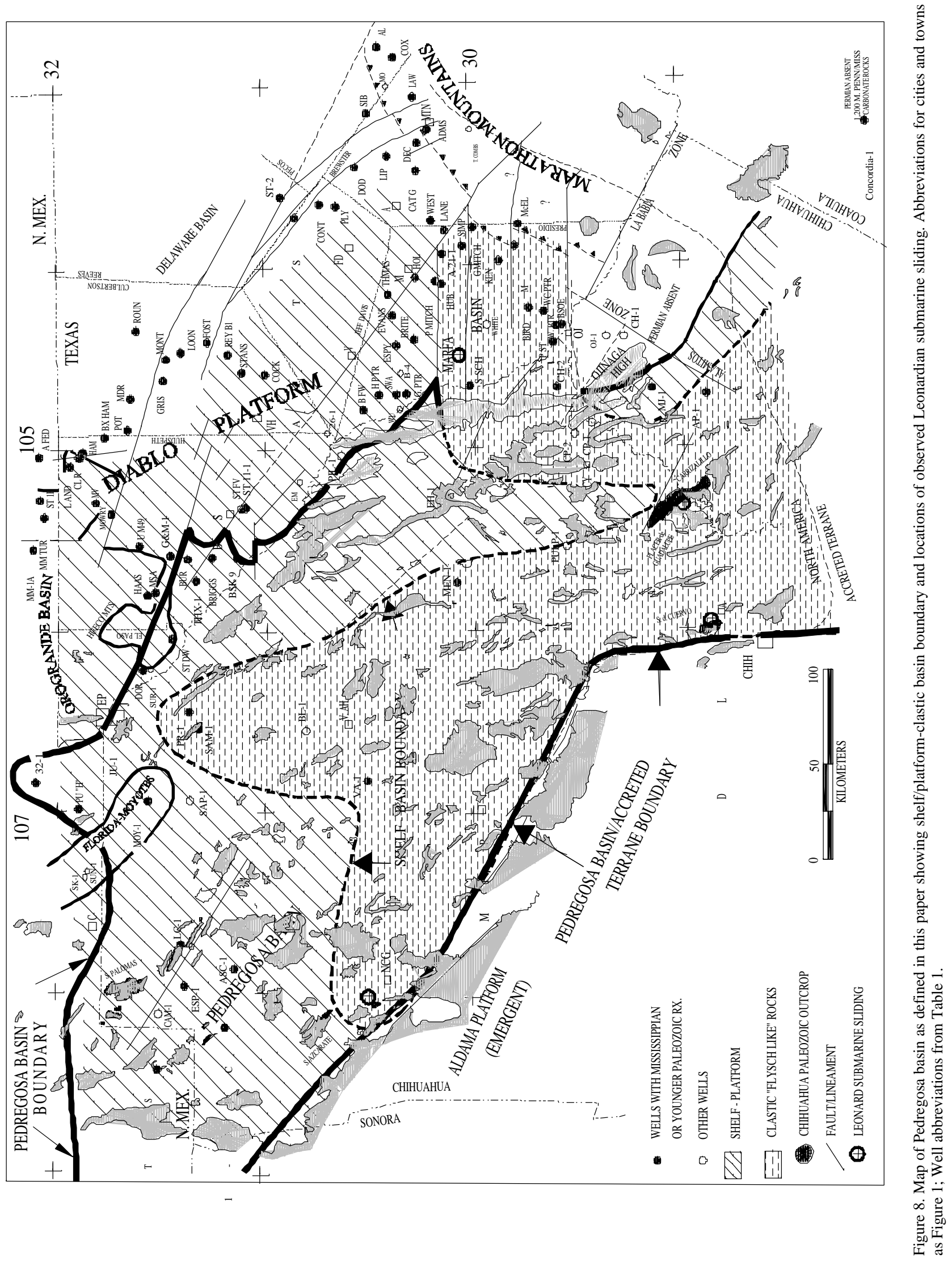


area to the southwest developed (or merely continued) into......., the Pedregosa trough. Virgilian time saw the repeat emergence of most of the triangle area. Near the Robledo Mountains the low islands were bordered on the east by shallow seas that hung precariously [sic] over the west margin of the deepening Orogrande trough". He described the Permian Florida islands as "The Florida islands during Wolfcampian time seem to have been low islands and hills on the south margin of a large low land mass stretching northward on which the Abo red beds were deposited, while to the south, southeast, and southwest, only a small amount of continental debris washed into marine basins".

To the southeast of the Florida islands there is some evidence of a more pronounced uplift on the FloridaMoyotes uplift. In the Tres Hermanas Mountains, one point of the "triangle" of Kottlowski et al. (1958), Kottlowski et al. (1969) mentioned that the lower $52 \mathrm{~m}$ of the Hueco Formation contains much chert-limestone pebble conglomerate interbedded with siliceous calcilutites, which is a suggestion of a source area of some relief. Two wells, Sunray Mid-Continent No. 1 New Mexico Federal "R" (SUN-1) and Skelly No. 1-A New Mexico "C" (SK-1), located in the extreme southeastern corner of Luna County, New Mexico, about $30 \mathrm{~km}$ southeast of the Florida Mountains, penetrated Tertiary sections overlying what appears to be Silurian Fusselman Dolomite (Kottlowski et al., 1969). The Sunray well was drilled with air and there is considerable doubt about the Fusselman: "....some of the lithologies do not fit with a designation of Fusselman ....... and can be fitted into the Permian, perhaps in a limited way with the Pennsylvanian, and in-part Lower Cretaceous" (Kottlowski et al., 1969). These wells do not confirm or refute Late Paleozoic uplift and erosion but they are on a trend that connects the Florida Mountains with the PEMEX Moyotes-1 well which, after drilling Lower Cretaceous and Upper Jurassic rocks, penetrated a Permian section described as Yeso-Hueco Limestone?-Abo overlying Precambrian granite (PEMEX files, 1973). It seems reasonable to speculate that the absence of Devonian, Mississippian and Pennsylvanian rocks in the Luna County wells can be related to Pennsylvanian-Permian deformation and erosion and that they are located on a late Paleozoic positive feature that connects the Florida islands with the Moyotes uplift. Truncated lower and middle Pennsylvanian isopachs against the Florida uplift (= FloridaMoyotes uplift) and facies interpretations support this speculation (Wilson, 1987a). It should be noted that the Laramide Burro uplift (Seager, 1983) is a northwesttrending, basement-cored uplift along a northwest extension of the Florida-Moyotes uplift.

\subsection{Pedregosa Basin}

Kottlowski recognized a Pennsylvanian depositional basin in the southeastern corner of Arizona that he termed the Pedregosa basin (cited by Ross, 1973). Kottlowski (1965) described a Pedregosa basin which, on his maps, occupies the panhandle of New Mexico, and a small part of Arizona ("open" to the south in Chihuahua and Sonora) as “......autogeosynclinal, receiving thick deposits of Middle Mississippian crinoidal limestones, Late Mississippian arenaceous calcarenites, Pennsylvanian limestones and Wolfcampian interbeds of limestone, black shale, and redbeds". Since these early descriptions, the term Pedregosa basin has been extended far into Mexico by several authors (Greenwood et al., 1977; Armin, 1987; Wilson, 1987a; Algeo and Wilson, unpublished manuscript; Thompson III et al., 1978).

The Pedregosa basin has been shown as a late Paleozoic feature that includes essentially all the area of the Mesozoic Chihuahua trough. Greenwood et al. (1977) defined the basin as the area where Pennsylvanian rocks are at least $600 \mathrm{~m}$ thick. Armin (1987) showed a Pedregosa basin that covers virtually all of northeastern Chihuahua, with a southern boundary along a projection of the Ouachita orogen into Chihuahua, immediately south of Placer de Guadalupe and Aldama. Wilson (1987a) extended the basin in a similar fashion but, based on the interpretation of distribution of "basinal rocks," included only the western part of the Chihuahua trough in the basin. He showed the eastern part of the trough as middle and lower Pennsylvanian "shelf?" and upper Pennsylvanian-lower Wolfcampian and upper Wolfcampian "shelf." Algeo and Wilson (unpublished manuscript) showed a fault-bounded Pedregosa basin (northwesttrending, right-lateral strike-slip) between a FloridaMoyotes-Mina Plomosas "high" and the Aldama platform. Thompson III et al. (1978) showed a Pennsylvanian Pedregosa basin, containing the Alamo-Hueco basin, which is similar to the basin shown by Wilson (1987a). López-Ramos (1969) referred to the general area as the Chihuahua basin and shows it to be the northernmost element of a southeast-trending Paleozoic geosyncline that extends southward to the latitude of Mexico City.

Herein, and with the desire to avoid stratigraphic arguments, the term Pedregosa basin is used for the area of deposition of late Paleozoic sediments within the area of the Chihuahua trough (Figure 8). In this definition, the southern boundary of the basin is arbitrary. This is in general agreement with Greenwood et al. (1977) and Armin (1987) and includes both shelf and basinal areas of Wilson (1987a). The Pedregosa basin includes the Alamo Hueco basin of Zeller (1965), part of the Marfa Basin of King (1948) and of Albritton and Smith (1965), the Fort Hancock basin of Ammon (1981), and the Chihuahua basin of López-Ramos (1969). To the south the basin connects with the Paleozoic geosyncline of LópezRamos (1969) .

There is reason to doubt about the existence of an extensive Mississippian Pedregosa basin in Chihuahua. Armstrong and Mamet (1978), on an isopach map, showed a northwest-trending Pedregosa basin in Missis- 
sippian rocks in Arizona and New Mexico. The axis of their basin passes through the junction of New Mexico, Arizona and Chihuahua. PEMEX Centauro-1 (CEN-1), about $15 \mathrm{~km}$ south of the map area of Armstrong and Mamet (op. cit.) penetrated $123 \mathrm{~m}$ of Mississippian rock (Thompson III et al., 1978) where projection of the map indicates about $400 \mathrm{~m}$ should be present. Similarly, projections of the map indicate that 300 to $400 \mathrm{~m}$ of Mississippian should be present in PEMEX Los Chinos-1 (LC1) where $746 \mathrm{~m}$ were encountered (PEMEX files, 1973). If these well data are incorporated into the map and it is recontoured, the basin axis shifts to a more or less easterly trend and contours are truncated by the Late Pennsylvanian-earliest Permian Florida-Moyotes uplift.

Wilson (1987a) stated that "To the south, in Chihuahua, there is neither proof nor disproof of the existence of the Pedregosa basin in earlier Pennsylvanian time". He went on to note that "Some limited stratigraphic evidence in the Big Hatchets would indicate that the Pedregosa basin perhaps began to develop late in Desmoinesian time".

The southwestern boundary of the Pedregosa basin is uncertain. In Sonora, near Bavispe, a thick (more than $1,000 \mathrm{~m}$ ) section of Mississippian, Pennsylvanian and Permian limestone (El Tigre Formation of LópezRamos, 1969) suggests that a carbonate shelf developed on a platform bounding the basin. Near Nuevo Casas Grandes, a Leonardian carbonate "flysch" contains "alleged" reworked Pennsylvanian shelf fossils (Pérez et al., 1984). Torres-Espinosa et al. (1987) measured a 677 meter thick section of these rocks and concluded that they were deposited on a platform margin that oscillated to deep-water conditions. Wilson (1987b, written communication) studied the Nuevo Casas Grandes section and concluded that the whole section is lower slope and deeper water strata and that the axis of the Pedregosa basin is northeast of the locality. In Sierra Azcárate, 30 km north of the Nuevo Casas Grandes "flysch," TorresEspinosa et al., measured $876 \mathrm{~m}$ of Pennsylvanian and Permian platform rocks, which they tentatively assigned to the Horquilla, Earp, and Colina formations. Thompson III et al. (1978), reported a "relatively thin section assigned to the Pennsylvanian" (440 m on isopach, $520 \mathrm{~m}$ in table) in PEMEX Centauro-1 (CEN-1) and suggested that this indicates a "deficient sediment supply in a deep marine ("starved") basin. On an isopach map, they showed the well on the axis of Pedregosa and Álamo Hueco basins.

The Greenwood et al. (1977) isopach maps show some 2,300 m of Pennsylvanian and Permian sediments in the deepest parts of the Pedregosa basin; LópezRamos (1969) showed similar thicknesses in the same area. These maximum thicknesses of Pennsylvanian and Permian rocks are compatible with incomplete sections of these rocks penetrated by PEMEX wells in the basin and with thicknesses reported from outcrops of these rocks within the basin.

PEMEX Los Chinos-1 (LC-1) spudded in Concha
Limestone (latest Leonardian) and drilled 1,925 $\mathrm{m}$ of Permian and Pennsylvanian rocks that are predominantly carbonates. The Humble State "BA-1" (St BA) in Hidalgo County, New Mexico, penetrated some 3,000 m of late Paleozoic rocks, including a thick middle Pennsylvanian section of dark cherty limestone with some shale and sandstone, that has been interpreted as "basinal" (Wilson, 1987a; Zeller, 1965). Zeller (1965) reported that this well found a thick Wolfcampian section $(1,312 \mathrm{~m})$ and considerable anhydrite in the Epitaph Dolomite (Leonardian?) and interpreted stratigraphic relations in the well to indicate a local basin during Wolfcamp time (Álamo Hueco basin). Outcrop studies in the Big Hatchet Mountains (Zeller, 1965), and in Chihuahua, particularly in Sierra Palomas, (Díaz-G. and Navarro-G., 1964; Sivils, 1987), show some 2,400 to 2,500 $\mathrm{m}$ of Pennsylvanian and Permian rocks that are largely carbonates.

PEMEX Villa Ahumada-1 (VA-1) penetrated $250 \mathrm{~m}$ of Leonardian dolomite and an incomplete section of $1,665 \mathrm{~m}$ of Wolfcampian rocks consisting of silty sandstone and siltstone (PEMEX files, 1973). PEMEX Menonita-1 (MEN-1) encountered $600 \mathrm{~m}$ of Late Paleozoic "turbidites" overlying an incomplete section of $600 \mathrm{~m}$ of "shelfal rocks" (Dyer, 1987). PEMEX Apache1 (AP-1), in the extreme southeastern part of the Pedregosa basin (as defined here) found an incomplete section of $466 \mathrm{~m}$ of Permian rocks that López-Ramos (1988) describes as metasedimentary Upper Paleozoic? rocks (limestones and phyllites) and Limón-González (1986) suggested are a "terrigenous facies". Some 3,500 $\mathrm{m}$ of Pennsylvanian and Permian rocks, including a thick "flysch like" section $(3,200 \mathrm{~m})$, occur in the Sierra Carrizalillo area (Dyer and Reyes, 1987). At Sierra Plomosas, Bridges (1962) reported as much as 2,700 m of Pennsylvanian, and presumably Permian (Plomosas conglomerate and "green formation") including a rhyolite (270 \pm 30 Ma, de Cserna et al., 1968) and allochthonous reef rocks (Montgomery, 1987). An incomplete section of late Paleozoic turbidites that may be as much as 2,600 m thick is exposed in the Sierra del Cuervo, near Aldama (López-Ramos, 1969).

In Sierra Samalayuca, at least 1,400 m (an incomplete 1,372-meter section was penetrated by PEMEX Samalayuca-1A (SAM-1), PEMEX files, 1973) of shale, sandstone and conglomerate (Samalayuca Formation) of probable late Paleozoic age are present. Berg (1969) suggested deposition in a near shore submarine fan and describes detrital components of conglomerate and sandstone, in order of abundance, as common quartz, vein quartz, and metamorphic rock fragments (metachert, slate, and marble) with quartz and metachert composing about 70 percent of the rocks. He suggested that the predominance of conglomerate along the northeast flank of the Sierra Samalayuca indicates a source to the north or northeast. Age of these rocks is unknown but RomeroMorales (1987) reported that J.L. Wilson, in a petrographic study of shell fragments collected by PEMEX, 
considered the fragments to be from brachiopods of possible Permian age. On a 1987 field trip, Barney Poole reportedly found pelmatazoa of probable PennsylvanianPermian age in the Samalayuca section possibly in a clast (P.W. Dickerson and T.F. Lawton, personal communications). About $10 \mathrm{~km}$ to the northeast of Sierra Samalayuca, PEMEX Presidio-1 (PR-1) encountered an incomplete section of $4,140 \mathrm{~m}$ of mudstone and sandy claystone which was tentatively called Jurassic (PEMEX files, 1973). It should be noted that, if there are no structural complications, this is by far the thickest Jurassic section reported in Chihuahua. There is a strong possibility that a large part of the section drilled in Presidio-1 is late Paleozoic because brachiopods of possible Pennsylvanian-Permian age were found $1,744 \mathrm{~m}$ into the section. Thus, approximately $2,396 \mathrm{~m}$ of these rocks are probably the result of deposition in a late Paleozoic basin.

A general thickening, toward Chihuahua, of Permian sections in wells and outcrops along the boundary between the Diablo Platform and the Chihuahua trough suggests that a Late Paleozoic basin or basins existed in the trough area. Perhaps the most spectacular example, which suggests a fault-bounded basin, is between the Western States Gardner and Moseley-1 (G\&M) on the Diablo Plateau and the Gulf Burner-1 (BUR) some 10 $\mathrm{km}$ to the south in the Finlay Mountains. The Gardner and Moseley-1 well found $70 \mathrm{~m}$ of Permian limestone underlying Cretaceous rocks and overlying Silurian rocks (Albritton and Smith, 1965) and the Gulf Burner-1 (BUR) spudded in Leonardian rocks, and passed through $1,813 \mathrm{~m}$ of Permian and Pennsylvanian rocks overlying a thin (28 m) Mississippian section (Pearson, 1980). This relationship can be interpreted as the result of development of a fault-bounded basin during late Paleozoic time or, possibly, as the result of post-Permian-preCretaceous uplift and erosion of the Diablo Platform. The latter, and Laramide thrust faulting, preclude drawing definitive conclusions other than upper Paleozoic rocks are present. Two other wells penetrated "complete" Permian sections along the Diablo PlatformChihuahua Trough boundary. The Humble State University "DW"-1 (ST DW) after penetrating 2,770 m of "bolson fill", found $161 \mathrm{~m}$ of Wolfcampian rocks before crossing a thrust fault into $484 \mathrm{~m}$ of Jurassic rocks underlain by $712 \mathrm{~m}$ of Leonardian/Guadalupian and Wolfcampian strata that include a 186-meter section of igneous rock that is presumably Tertiary. The Border Exploration Bask State "9"-1 (BSK 9), west of the northern Quitman Mountains, reportedly penetrated 2,154 m of Permian and Pennsylvanian rocks (Osburg et al., 1985). Interpretation of sample, sonic and dipmeter logs of this well (logs courtesy of Texaco) suggests that the section referred to by Osburg et al. (op. cit.) consists of Jurassic and Permian rocks repeated by a thrust fault below the Permian in the footwall, a possible section of Upper Pennsylvanian rock (sandstone, gray-purple shale, some glauconite) and rocks equivalent to the Woodford Formation. Permian and possible Pennsylvanian rocks in the footwall are $606 \mathrm{~m}$ thick (corrected for dip).

\subsubsection{Speculations}

Figure 8 is an interpretation of the prevalent distribution of shelf and deeper water clastic depositional regimes during latest Pennsylvanian and Permian time. From sometime late in the Pennsylvanian and throughout the Permian, much of the Pedregosa basin was rimmed by shelves that were principally sites of carbonate deposition. The southwestern and western side of the basin was probably bounded by an accreted continental terrane where a basement-metamorphic complex was being unroofed. To the southeast, the basin was connected to the Marfa Basin. The western and central parts of the basin were sites of thick clastic sedimentation.

The shelf is well documented in the northwest and along the northern and eastern margins of the Pedregosa basin (Greenwood et al., 1977; Wilson, 1987a; and many others). The shelf-deeper water boundary within the basin is a speculation based on interpretations of data from the Nuevo Casas Grandes area, PEMEX Villa Ahumada1 (VA-1), Sierra Samalayuca, PEMEX Presidio-1 (PR1), PEMEX Menonita-1 (MEN-1), the Plomosas uplift, PEMEX Maijoma-1 (MJ-1), PEMEX Apache-1 (AP-1), and Bouguer gravity maps. The accreted terrane is based on sedimentary studies at Sierra del Cuervo by Handschy and Dyer (1987), interpretation of satellite and shuttle imagery, an interpretation that extends ) $\mathrm{Pb}$ isotope boundary of North America (James and Henry, 1993), Bouguer gravity maps, and interpretation of provenance of Precambrian and Permian clasts in conglomerate at the Sierra Mojina.

\subsubsection{Carbonate Shelf - Clastic Boundary}

Exposures of Paleozoic rocks at La Vinata, about 10 $\mathrm{km}$ northwest of Nuevo Casas Grandes (see Figure 8 for location), are described by several authors. Wilson (1987b, written communication) described the section as lower slope and deep water from observation of partial Bouma sequences A-B-C, major graded beds consisting of turbidites and debris flows, and common laminated, chert-bearing, lime mudstone. All fossils observed are shallow water forms and include corals, brachiopods, bryozoans, crinoids, and fusulinids in great abundance. This fauna is interpreted as an accumulation on a slope into a basin and is derived from a nearby shelf. His conclusion is that the section represents a slope section off a platform to the southwest. Torres-Espinosa et al. (1987) reported the occurrence of Leonardian fossils in these rocks and described the sedimentary environment as, "on the border of an open platform with some oscillations to deep-water conditions" (quote translated from Spanish).

PEMEX Villa Ahumada-1 (VA-1) penetrated $250 \mathrm{~m}$ of Leonardian Dolomite before entering an incomplete section of $1,665 \mathrm{~m}$ of Wolfcampian silty sandstone and siltstone (PEMEX files, 1973). This suggests that a carbonate platform was located fairly close to the well during Wolfcampian time and prograded to the well site 
during Leonardian time.

The entire section at Sierra de Samalayuca consists of shale, sandstone and conglomerate that are interpreted as the result of deposition on a near shore submarine fan (Berg, 1969). If part or all the Samalayuca section is Permian, the apparent presence of Hueco Limestone in PEMEX Moyotes-1 (MOY-1) indicates that the shelf edge is somewhere between this well and the Sierra Samalayuca. Similarly, the presence of possible Permian mudstones and sandy claystones in PEMEX Provincia-1 (PR1) indicate a shelf edge between the well and the Hueco Limestone deposits of the Hueco Mountains.

"Turbidites" reported in PEMEX Menonita-1 (MEN1) give a minimum eastward extent of the clastic facies. There is no data to preclude extending this facies from the well to the Marfa Basin. A postulated shelf area north of Placer de Guadalupe may separate this well from the Marfa Basin and may be an extension of the shelf areas north of that basin (Figure 8). Alternatively the postulated shelf may have developed on a locally uplifted area in the late Paleozoic sea as suggested by Ross and Ross (1985, "Minas Plomosas platform"). Across this shelf to the east there is no data to confirm the shelf-basin boundary shown on Figure 8. In the Pinto Canyon area, near the intersection of the Marfa and Pedregosa basin Amsbury (1958) described Leonardian submarine-slide blocks that suggest a nearby shelf-basin boundary.

The interpretation of Montgomery (1987) of stratigraphic relationships between Permian patch reefs in the Sierra Plomosa-Sierra Santo Domingo area of the Plomosas Uplift are the basis for interpretation of the shelf area north of Placer de Guadalupe. He described the reefs as all, or in part, allochthonous, progressively younger from north to south, and emplaced in a tectonically influenced prograding margin. Montgomery further stated that this event is coeval with or possibly slightly earlier than Leonardian "tectonic adjustments" in the Permian Basin. Significantly these reef rocks are not present in the Permian section in the vicinity of Cerro El Carrizalillo some $10 \mathrm{~km}$ southeast of Sierra Santo Domingo. A platform area, of uncertain extent, is indicated to the north of Placer de Guadalupe.

The thick Permian clastic section near Cerro El Carrizalillo (Cerro Pañales, Roberts and Dyer, 1988) and the presence of Permian "terrigenous" rocks in PEMEX Apache-1 (AP-1) indicate a clastic basin that is interpreted as an extension of the Marfa Basin. Absence of Permian rocks in PEMEX Maijoma-1 (MJ-1) and Ojinaga-1 (OJ-1) indicate that the Ojinaga area could have been emergent during Permian time. Whether or not Permian shelf rocks were deposited around the fringe of the uplift is conjecture. However, Pennsylvanian and Mississippian carbonate rocks in Maijoma-1 (López-Ramos, 1988) and a similar absence of Permian and presence of Pennsylvanian and Mississippian carbonate rocks in a well in Coahuila, PEMEX Concordia-1 (Santamaría et al., 1991), indicate that a shelf was present along the southwestern edge of the Ojinaga area during at least part of Late Paleozoic time.

Lenticular limestones containing Wolfcampian fusulinids occur within the Rara Formation at Sierra del Cuervo (Pearson et al., 1964). This author noted that there has been considerable discussion whether or not these limestones are erratic blocks and that they are the same age as the patch reefs in the Placer de Guadalupe area. If they are erratics, they could reflect Late Wolfcampian-Leonardian "tectonic adjustments" similar to those described by Montgomery (1987) near Placer de Guadalupe and be indicative of a nearby platform that is not shown on Figure 8.

\subsubsection{Basin Development}

Origin of the Pedregosa basin is not clear. Goetz and Dickerson (1985) described Devonian-Pennsylvanian development of a Pedregosa basin that was a shallow, intra-shelf basin on a foundation of thinner crust and narrow northwest-oriented basement blocks which rapidly adjusted to application of stresses from the west and east part of a postulated Paleozoic transform margin of North America. The southeastern end of the basin was open and the seas shallowed toward the northwest. Armstrong and Mamet (1978) showed a thickening of Mississippian rocks along a northwest-trending axis, from the southeastern tip of Arizona, across the New Mexico panhandle and, by inference, heading into Chihuahua. As previously discussed, data from PEMEX wells Centauro-1 (CEN-1) and Los Chinos-1 (LC-1) suggest that a projection of this trend into Chihuahua as shown by Greenwood et al. (1977), may be an oversimplification, as there is no evidence in Chihuahua to support extension of an early Pedregosa basin (Devonian-Mississippian) to the southeast from the area of Mississippian thickening shown by Armstrong and Mamet (op. cit.), nor is there a great amount of data that precludes such an extension.

By medial Pennsylvanian time (Atokan- Desmoinesian) some northwesterly tectonic trends were established in the general region of northeastern Chihuahua, but there is no evidence to prove or disprove the existence of a Pedregosa basin in Chihuahua. Where they are recognized in Chihuahua and in Coahuila (PEMEX Concordia-1), lower Pennsylvanian rocks are carbonates suggesting widespread shelf-platform depositional conditions.

There are some hints of early Pennsylvanian tectonism that influenced topography. In the Placer de Guadalupe region the Pastor Limestone which is in part Desmoinesian or older, thickens toward the northwest from $250 \mathrm{~m}$ near Cerro de Enmedio to approximately $500 \mathrm{~m}$ west of Placer de Guadalupe (Bridges, 1964). Southeast from Cerro de Enmedio, the Pastor thickens to $280 \mathrm{~m}$ at Cerro Carrizalillo (Dyer and Reyes, 1987). In the northwest part of the Chihuahua Trough, Wilson (1987a) presents an isopach map that shows pronounced thickening of middle and lower Pennsylvanian carbonate rocks (some $200 \mathrm{~m}$ over a distance of $30 \mathrm{~km}$ ). The changes in 
thickness of Lower Pennsylvanian rocks may reflect development of a tectonically induced topography during deposition of the carbonate rocks. During this period, initial subsidence of the Orogrande Basin began (Algeo et al., 1991). The Orogrande Basin, adjacent to the Pedregosa basin, was interpreted as an intracratonic trough with a fault-bounded, narrow eastern shelf that formed during the Ouachita-Marathon orogeny (Algeo et al., 1991).

It can be speculated that early Pennsylvanian leftlateral displacements along segments of the Texas Lineament zone and northwest-trending zones southwest of the Texas Lineament, e.g. fault northeast of Placer de Guadalupe, and zone along the postulated boundary of North America in Chihuahua (Figures 4 and 8) caused relatively local pop-up and basinal structures that influenced carbonate deposition within the Pedregosa basin. A more far-reaching speculation is that clues indicating the existence of Mississippian and possibly Devonian depocenters in the Pedregosa basin reflect the docking of the accreted continental terrane along the southwestern and western part of the basin, and that these depocenters were an incipient foreland basin or basins. In this scenario, the early Pennsylvanian effects and postulated left-lateral regime are continuations of the docking process.

In late Pennsylvanian-earliest Permian time existed considerable tectonic unrest in the general region of the Chihuahua Trough and the Pedregosa basin. The FloridaMoyotes uplift, Hueco Mountains, Diablo Platform and the basement-cored terrane west of the Sierra del Cuervo were elevated and subjected to erosion. The Marfa Basin developed as a foreland synorogenic basin and, in response to predominantly vertical movements, extensive clastic deposits accumulated over wide areas of the Pedregosa basin.

In the northwestern extremity of the Pedregosa basin, there is stratigraphic evidence for the presence of an approximately 50-kilometer-wide graben along a northwest-trending zone that extends from the Big Hatchet Mountains (within the graben), across the New Mexico panhandle and into Arizona (Ross, 1973). Ross suggested the graben because of rather abrupt thickening of the Horquilla Limestone (Pennsylvanian-Early Wolfcampian) and Earp Formation (Wolfcampian) across possible faults. This graben is along the trend of the northwesterly fault zone shown on Figure 8 between PEMEX Los Chinos-1 (LC-1) and Espía-1 (ESP-1), and the northernmost graben-bounding fault coincides with it. There is some $5,000 \mathrm{~m}$ of down-to-the-south structural relief on the Permian between these wells that may be all, or in part, caused by displacement during late Paleozoic deposition. Espia-1 (ESP-1) was abandoned while drilling in the Epitaph Formation (latest Wolfcampian) and thus it is impossible to use the wells to determine the effects, if any, of syndepositional fault movements on thickness of the Pennsylvanian and lower Permian section. Thickness of the Horquilla and Earp formations in
Los Chinos-1 (LC-1) is 1,529 m (PEMEX notes, 1973), which is similar to reported thickness of $1,748 \mathrm{~m}$ in Humble State-1 "BA" (ST BA) and 1,380 $\mathrm{m}$ in the Big Hatchet Mountains (Zeller, 1965). The southernmost of graben-bounding faults postulated by Ross (op. cit.) projects into Chihuahua somewhere south of PEMEX Centauro-1 (CEN-1) and cannot be recognized in Mexico. This well penetrated 3,730 $\mathrm{m}$ of Permian and Pennsylvanian rocks (Thompson III et al., 1978), which is the thickest known section of this age in the Pedregosa basin.

Right-lateral and vertical movements of northwesttrending fault zones along the southwestern edge of North America, during late Pennsylvanian and/or early Permian time are discussed by several authors (Goetz and Dickerson, 1985; Hills, 1970). These authors ascribe the driving force as a consequence of the OuachitaMarathon orogeny. Development of the late Pennsylvanian Pedregosa basin has been associated with a stress regime that caused right-lateral and vertical movements along faults bounding the Diablo Platform, the Orogrande Basin, Florida-Moyotes uplift and the Aldama Platform (Algeo and Wilson, unpublished manuscript). Handschy and Dyer (1987) suggested that late Paleozoic structures in the Sierra del Cuervo are related to Ancestral Rocky Mountain deformation and state that additional evidence for this is found in other parts of northern and central Chihuahua. According to Kluth and Coney (1981) the Ancestral Rocky Mountain uplifts are a consequence of the collision between North America and South America that caused the Ouachita-Marathon orogeny.

The postulated Permian folding along a left-lateral, northwest-trending fault at Placer de Guadalupe, and thrusting that may be related to left-lateral movements along the boundary of North America in the Sierra del Cuervo indicate that there may be local complications associated with the suggested late Pennsylvanian/early Permian right-lateral regime of Goetz and Dickerson (1985) and Algeo and Wilson (unpublished manuscript). A clockwise rotation of all or part the Pedregosa basin between the accreted terrane and the Diablo Platform could be an explanation; an attempt to justify this is beyond the pale of these speculations. Similarly, details of deformation in the postulated accreted-terrane source area are impossible to document; suffice to say there is evidence of an elevated basement-cored source area and that the distribution of predominantly clastic, "flyschlike" rocks in the Pedregosa basin suggest that a syntectonic basin formed along the border of a terrane that is now coincident with the Aldama Platform (sometimes referred to as Sierra del Nido uplift). Distribution of "flysch-like" Permian rocks in Mexico suggest that this basin or similar basins extended southward to the latitude of Mexico City and were connected to an "Atlantic Ocean" between Cd. Victoria and Tampico, Tamaulipas (from maps and data of López-Ramos, 1969). 


\section{Summary}

The Chihuahua trough, a Mesozoic depositional basin occupying northeastern Chihuahua and adjacent parts of Texas, New Mexico and northeastern Sonora, has a long and complex tectonic history. Northwest-trending lineaments that transect the southern margin of Paleozoic North America have been intermittently active from the Middle Proterozoic to the present.

The Precambrian history of this region is compiled from outcrops and wells in Trans-Pecos, Texas, two outcrop areas along the southern edge of the Chihuahua trough and four wells that penetrate Precambrian rocks in the trough. The 1,400-1,300 Ma deposition of Carrizo Mountain Group rocks and intrusion of 1,350-1,270 Ma granitic rocks are the earliest recorded events in the region. At around 1,260 Ma, north-trending De Baca rifting affected areas to the north and can be inferred to extend into northeastern Chihuahua; at about the same time rocks of the Carrizo Mountain Group underwent their first metamorphism. At around 1,100 Ma, the region was subjected to "Grenville" diastrophism which includes extensive batholith emplacement (Franklin Mountains igneous group and Llano Province), Steeruwitz thrusting, retrograde metamorphism of the Carrizo Mountain Group and synorogenic deposition of the Hazel Formation in the Van Horn, Texas area. The Franklin Mountains igneous province is postulated to floor most of the Chihuahua trough. The position of the westward continuation of the Llano Front across Chihuahua is unknown.

Evidence for early Paleozoic tectonism is scant, except for the middle Ordovician departure of Cuyania, which occupied the region east of the La Babia zone. Four distinct episodes of late Paleozoic tectonism can be identified in the region. The first three events were first identified in the Marathon thrust belt: 1) MississippianPennsylvanian deformation in the hinterland of the thrust belt (Meramecian-Atokan with a pause during Morrowan); 2) Pennsylvanian orogeny (DesmoinesianMissourian); 3) Pennsylvanian-Permian folding and thrusting (Virgilian-Early Wolfcampian). These events are also recognized throughout the Ancestral Rockies. The last event is: 4) Permian (Late WolfcampianLeonardian- Guadalupian?) erosion/truncation and subsequent tilting.

Some or all of these events are recognized from mapping and subsurface data in the mountain ranges and basins: Hueco Mountains, Sierra Diablo region-northern Diablo Platform, southern Diablo Platform, Marfa Basin, Ojinaga area, Placer de Guadalupe-Carrizalillo, Sierra del Cuervo, Florida-Moyotes uplift, Pedregosa basin. Although details of the configuration of the Pedregosa basin in Chihuahua are uncertain, it consisted of a wide platform across the northern and eastern part of the Chihuahua trough and a deep clastic ("flysch-like) trough in central Chihuahua that extended northeastward into the Marfa Basin.

\section{Acknowledgments}

This paper resulted from an attempt to "catch up" with what has been learned and published on the tectonics of northeastern Chihuahua since I completed my dissertation in 1966. Bill Muehlberger suggested the study, convinced me to do it and provided images, maps and literature. He discussed and reviewed the work as it progressed and contributed many ideas that are incorporated into the paper. Pat Dickerson provided many thoughts, observations, and interpretations from her extensive work in the general area. She reviewed the manuscript as it developed and made her extensive library and knowledge of the literature available. Dave Amsbury provided insights and reviewed the manuscript. Tim Lawton reviewed the manuscript and offered suggestions for changes and clarification.

Seismic lines and well data in the vicinity of the Quitman and Eagle mountains were provided by Texaco through the efforts of Susan Longacre and Vic Smith. Data on wells in the Marfa Basin were provided by Pat Dickerson, Jim Wolleben, formerly with Gulf, and Dave Greenlee, formerly with Mobil. During the 1960s and early 1970s Teodoro Díaz G., Arsenio Navarro G., Jorge Tovar R. and J. Valencia R. provided their interpretations of PEMEX petroleum exploration efforts in Chihuahua. Fred McDowell explained the significance of isotope studies for delineation of the North American craton.

\section{References}

Albritton, C.C., Smith, J.F, 1957, The Texas lineament, in XX Congreso Geológico Internacional, Relaciones entre la tectónica y la sedimentación: México, D. F., International Geological Congress, v. 2, 501-518.

Albritton, C.C., Smith, Jr., J.F., 1965. Geology of the Sierra Blanca area, Hudspeth County, Texas: Washington, D.C., U.S. Geological Surevey, Professional Paper, 479, $131 \mathrm{p}$.

Algeo, T.J., Wilson, J.L., Lohmann, K.C., 1991, Eustatic and tectonic controls on cyclic sediment accumulation patterns in lowerMiddle Pennsylvanian strata of the Orogrande basin, New Mexico, in Geology of the Sierra Blanca, Sacramento and Capitan Ranges. 42nd Annual Field Conference, Guidebook: New Mexico, New Mexico Geological Society, 203-212.

Almazán-Vázquez, E., Fernández-Aguirre, M.A., 1987, Los terrenos paleozoicos de la región serrana de Sonora, in Paleozoico de Chihuahua: Sociedad Geológica Mexicana, La Gaceta Geológica, 1 (1), 97-104.

Ammon, W.L., 1981, Geology and plate tectonic history of the Marfa Basin, Presidio County, Texas, in Marathon - Marfa Region of West Texas, Permian basin, symposium and guidebook: Midland, Texas, Society of Economic Paleontologists and Mineralogists, 75-101.

Amsbury, D.L., 1958, Geologic map of Pinto Canyon area, Presidio County, Texas, witgh structure sections: Texas University, Bureau of Economic Geology, Geologic Quadrangle Map, núm. 22, 1 map.

Armin, R.A., 1987, Sedimentology and tectonic significance of Wolfcampian (lower Permian) conglomerates in the Pedregosa basin; southeastern Arizona, southwestern New Mexico, and northern Mexico: Geological Society of America Bulletin, 99, 42-65.

Armstrong, A.K., Mamet, B.L., 1978, The Mississippian System of 
southwestern New Mexico and southeastern Arizona, in Callender, J.F., Wilt, J.C., Clemons, R.E., James, H.L. (eds.), Land of Cochise, southeastern Arizona: New Mexico Geological Society, Guidebook, núm.29, 183-192.

Baker, C.L., 1929, Note on the Permian Chinati Series of West Texas: University of Texas Bulletin, 2901, 73-84.

Baker, C.L., 1934, Major structural features of Trans-Pecos Texas, in The Geology of Texas, Volume II, Structural and Economic Geology: Texas Bureau of Economic Geology, Bulletin, 3401, 137-214.

Beard, T.C., 1983, Photogeology of the Spike "S" Ranch, southern Hueco Mountains, Hudspeth County, Texas: El Paso, Texas, University of Texas at El Paso, M.S. Thesis, 65 p.

Beard, T.C., 1985, Notes on Paleozoic structures of the Hueco Mountains, Hudspeth and El Paso counties, Texas, in Structure and Tectonics of Trans-Pecos Texas: West Texas Geological Society, Publication, núm. 85-81, 123-126.

Beck, W.C., Chapin, C.E., 1991, Structural data from the Joyita uplift: implications for ancestral Rocky Mountain deformation within central and southern New Mexico, in Geology of the Sierra Blanca, Sacramento and Capitan Ranges, New Mexico. 42nd Annual Field Conference: New Mexico, New Mexico Geological Society, 183-190.

Berg, E.L., 1969, Geology of Sierra de Samalayuca, Chihuahua, Mexico, in Guidebook of the border region: Santa Fe, New Mexico, New Mexico Geological Society, 176-181.

Black, B.A., 1976, Tectonics of the northern and eastern parts of the Otero platform, Otero and Chaves counties, New Mexico, in Tectonic and mineral resources of southwestern North America: Socorro, New Mexico, New Mexico Geological Society, Special Publication, núm. 6, 39-45.

Bridges, L.W., 1962, Geology of Mina Plomosas area, Chihuahua, Mexico: Austin, Texas, University of Texas at Austin, Ph. D. Thesis, $240 \mathrm{p}$.

Bridges, L.W., 1964, Stratigraphy of Mina Plomosas-Placer de Guadalupe area, in Geology of Mina Plomosas-Placer de Guadalupe area, Chihuahua, Mexico. Field trip guidebook: West Texas Geological Society, Publication, núm. 64-50, 50-59.

Cantú-Chapa, C.M., Sandoval-Silva, R., Arenas-Partida, R., 1985, Evolución sedimentaria del Cretácico inferior en el norte de México: Revista del Instituto Mexicano del Petróleo, XVII (2), 14-37.

Charleston, S., 1981, A summary of the structural geology and tectonics of the State of Coahuila, Mexico, in Charleston, S.; Smith, Ch. I., Brown, J., B. (eds.), Lower Cretaceous stratigraphy and structure, northern Mexico; Field trip guidebook: West Texas Geological Society, Publication, núm. 81-74, 28-36.

Clemons, R.E., Mack, G.H., 1988, Geology of southwestern New Mexico, in Mack, G. H.; Lawton, T. F., Lucas, S. G. (eds.), Cretaceous and laramide tectonic evolution of southwestern New Mexico: New Mexico, New Mexico Geological Society, Guidebook, núm. 39, 45-57.

Cohee, G.V. (chairman), 1961, Tectonic map of the United States exclusive of Hawaii and Alaska: United States Geological Survey, American Association of Petroleum Geologists, 1 mapa.

Comer, J.B., 1991, Stratigraphic analysis of the Upper Devonian Woodford Formation, Permian basin, west Texas and southeastern New Mexico: Texas University, Bureau of Economic Geology, Report of Investigations, núm. 201, 63 p.

De Cserna, Z., 1966, Notes concerning the geology of the Placer de Guadalupe and Plomosas region, Chihuahua; from translation into english by Dan Bridges and Bruce Perason, in Cserna, Z. de, Estudios geológicos en el estado de Chihuahua: México, D.F., Universidad Nacional Autonóma de México, Instituto de Geología, Boletín, núm. 74, part 2, 135-146.

De Cserna, Z., Rincón-Ortega., C., Solorio-Munguía, Schmitter, V., 1968, Una edad radiométrica Pérmica temprana de la región de Placer de Guadalupe, noreste de Chihuahua: Boletín de la Sociedad Geológica Mexicana, 31, 65-73.

DeFord, R.K., 1964, History of geologic exploration in Chihuahua, in Geology of Mina Plomosas-Placer de Guadalupe area, Chihuahua, Mexico; Field trip giuidebook: West Texas Geological Soci- ety, Publication, núm. 64-50, 116-129.

DeJong, H.W., Addy, S.K., 1992a, Trans-Pecos Texas; 1, Only relatively small production seen in basins of far West Texas: Oil and Gas Journal, 90 (3), 59-65.

DeJong, H.W., Addy, S.K., 1992b, Trans-Pecos Texas; 2, (conclusion), Broad view indicates hydrocarbon potential low in far West Texas: Oil and Gas Journal, 90 (4), 97-102.

Denison, R.E. Hetherington, E.A., 1969, Basement rocks in far West Texas and south-central New Mexico, in Border stratigraphy symposium: New Mexico Bureau of Mines and Mineral Resources, Circular, núm. 104, 13 p.

Denison, R.E., Burke, W.H. Jr., Hetherington, E.A. Otto, J.B., 1970, Basement rock framework of parts of Texas, southern New Mexico and northern Mexico, in The geologic framework of the Chihuahua tectonic belt; Symposium in honor of Professor Ronald K. DeFord: Austin, Texas, West Texas Geological Society; The University of Texas at Austin, 4-6.

Denison, R.E., 1980, Pre-Bliss (PC) rocks in the Van Horn region, Trans-Pecos, Texas, in Dickerson, P. W., Hoffer, J. M., Callender, J. F. (eds.), Trans-Pecos Region, southeastern New Mexico and West Texas: New Mexico Geological Society, Guidebook, núm. 31,155-158.

Denison, R.E., Lidiak, E.G.; Bickford, M.E., Kisvarsanyi, E. B.,1984, Geology and geochronology of Precambrian rocks in the central interior region of the United States: Reston, Virginia, U.S. Geological Survey, Professional Paper, núm. 1241-C, p. C1-C20.

Díaz-G., T., 1964, Interpretación esquemática de la estructura perforada por el pozo de exploración Chapo-2, in Geology of Mina Plomosas-Placer de Guadalupe area, Chihuahua, México; Field trip guidebook: West Texas Geological Society, Publication, núm. 64-50, 15.

Díaz-G., T., Navarro-G., A., 1964, Lithology and stratigraphic correlations of the Upper Paleozoic in the region of Palomas, Chihuahua, in Geology of Mina Plomosas-Placer de Guadalupe area, Chihuahua, Mexico; Field trip guidebook: West Texas Geological Society, Publication, núm.64-50, 65-84.

Dickerson, P.W., 1980, Structural zones transecting the southern Rio Grande rift - Preliminary observations, in Dickerson, P. W., Hoffer, J. M., Callender, J. F. (eds)., Trans-Pecos region, southeastern New Mexico and West Texas: New Mexico Geological Society Guidebook, núm. 31, 63-70.

Dickerson, P.W., 1995, Tascotal Mesa transfer zone, Rio Grande rift of West Texas (Presidio, Brewster counties); a structural mechanical and thermal characterization: Austin, Texas, University of Texas at Austin, Ph. D. Thesis, 189 p.

Dickerson, P.W., Keller, M. 1998. The Argentine precordillera: its odyssey from the Laurentian Ouachita margin towards the Sierras Pampeanas of Gondwana, in Pankhurst, R. J., and Rapela, C. W. (eds.), The proto-Andean Margin of Gondwana: London, Geological Society, Special Publication 142, 85-105.

Dietrich, J.W., 1966, Geology of Presidio Area, Presidio County, Texas: Texas, University, Bureau of Economic Geology, Geologic Quadrangle Map, núm. 28, 1 map, 45 p.

Drewes, H.D., 1981, Tectonics of southeastern Arizona: Reston, Virginia, U.S. Geological Survey Professional Paper, núm. 1144, 96 p.

Dyer, R., 1987, Road log from El Paso/Juarez via Villa Ahumada, El Sueco to Ciudad Chihuahua, in Libreto guía de caminos, Excursión geológica: Sociedad Geologica Mexicana, Universidad Autonoma de Chihuahua, University of Texas at El Paso, 2-31.

Dyer, J. R., Hanshaw, P.M., 1989, Structural geology of the Franklin Mountains, west Texas, in Muehlberger, W.R., Dickerson, P.W., (leaders), Sedimentation and tectonics of Western North America. Volume 3, Structure and stratigraphy of Trans-Pecos Texas: Washinton, D.C., American Geophysical Union, 65-70.

Dyer, R., Reyes, I., 1987, The geology of Cerro El Carrizallilo, Chihuahua, Mexico: Sociedad Geológica Mexicana, La Gaceta Geológica, 1(1), 108-128.

Eardley, A.J., 1962, Structural geology of North America, second edition: New York, Harper and Row, 743 p.

Flawn, P.T., 1953, Carrizo Mountains, in King, P.B., Flawn, P.T. (eds.), Geology and mineral deposits of Pre-Cambrian rocks of 
the Van Horn Area, Texas: University of Texas. Bureau of Economic Geology, Publication, núm. 5301, 51-69.

Flawn, P.T., 1961a, The Ouachita structural belt in Mexico, in The Ouachita System: University of Texas, Bureau of Economic Geology, Publication, núm. 6120, 99-106.

Flawn, P.T., 1961b, Summary reports on wells penetrating rocks of the Ouachita belt and immediately adjacent foreland in Texas; Part 1 of appendix,: in The Ouachita System: University of Texas, Bureau of Economic Geology, Publication, núm. 6120, 211-338.

Flower, R. H., 1958, Cambrian-Mississippian beds of southern New Mexico, in 11 th Field Conference Guidebook: Roswell Geological Society, 67-78.

Goetz, L.K., Dickerson, P.W., 1985, A Paleozoic transform margin in Arizona, New Mexico, west Texas and Mexico, in Dickerson, P. W., Muehlberger, W.R. (eds.), Structure and tectonics of TransPecos Texas: West Texas Geological Society, Publication núm. 85-81, 173-184

Gordon, M.B., Hempton, M.R., 1986, Collision-induced rifting; the Grenville orogeny and the Keweenawan rift of North America: Tectonophysics, 127, 1-25.

Greenlee, D.W., 1970, Paleozoic history of the Diablo Platform south of Van Horn, Texas, in The geologic framework of the Chihuahua Tectonic Belt; symposium in honor of Professor Ronald K. DeFord: Austin, Texas, West Texas Geological Society; The University of Texas at Austin, p. 65.

Greenwood, E., Kottlowski, F.E., Thompson, III, S., 1977, Petroleum potential and stratigraphy of Pedregosa basin; comparison with Permian and Orogrande basins: American Association of Petroleum Geologists, Bulletin, 61, 1448-1469.

Gries, J.C., 1970, Geology of the Sierra de la Parra area, northeast Chihuahua, Mexico: Austin, Texas, University of Texas at Austin, Ph. D. Thesis, 193 p.

Gries, J.C., Haenggi, W.T., 1970, Structural evolution of the eastern Chihuahua tectonic Belt, in The geologic framework of the Chihuahua Tectonic Belt; symposium in honor of Professor Ronald K. DeFord: Austin, Texas, West Texas Geological Society; The University of Texas at Austin, 119-137.

Haenggi, W.T., 1966, Geology of El Cuervo area, northeastern Chihuahua, Mexico: Austin, Texas, University of Texas at Austin, Ph. D. Thesis, $403 \mathrm{p}$.

Handschy, J.W., Keller, G.R., Smith, K.J., 1987, The Ouachita system in northern Mexico: Tectonics, 6, 323-330.

Handschy, J.W., Dyer, R., 1987, Polyphase deformation in Sierra del Cuervo, Chihuahua, Mexico: Geological Society of America, Bulletin, 99, 618-632.

Harrison, J.V., Falcon, N.L., 1936, Gravity collapse structures and mountain ranges as exemplified is southwestern Iran (with discussion): Quaterly Journal of the Geological Society London , 92 (365), 91-102.

Hayes, P. T., 1978, Cambrian and Ordovician rocks of southeastern Arizona and southwestern New Mexico, in Callender, J.F., Witt, J.C., Clemons, R.E., J.-L. (eds.), Land of Cochise; southeastern Arizona: New Mexico Geological Society, Guidebook, núm.29, 165-173.

Hennings, P.H., 1991, Structural studies of the Chihuahua tectonic belt: Austin, Texas, University of Texas at Austin, Ph. D. Thesis, $145 \mathrm{p}$.

Hennings, P.H., 1994, Structural transect of the southern Chihuahua Tectonic Belt between Ojinaga and Aldama, Chihuahua, Mexico: Tectonics, 13(6), 1445-1460.

Hills, E.S., 1963, Elements of structural geology: New York, John Wiley, $483 \mathrm{p}$.

Hills, J.M., 1970, Late Paleozoic structural directions in southern Permian Basin, west Texas and southeastern New Mexico: Bulletin of the American Association of Petroleum Geologists, 54, 18091827.

Hobbs, B.E., Means, W.D., Williams, P.F., 1976, An outline of structural geology: New York: John Wiley, $571 \mathrm{p}$.

Hoffman, P.F., 1989, Precambrian geology and tectonic history of North America, in, Bally, A.W., Palmer, A.R. (eds.), The Geology of North America: an overview: Boulder, Colorado, Geological Society of America, Geology of North America, v. A.,
447-512.

James, E.W., Henry, C.D., 1993, Pb isotopes of ore deposits in TransPecos Texas and northeastern Chihuahua, Mexico; basement, igneous and sedimentary sources of metals: Economic Geology, 88, 934-947

Keller, G.R., Dyer, R., 1989, The Paleozoic margin of North America in west Texas and northern Mexico: Geofisica International, 28 (5), 897-906.

King, P.B., 1937, Geology of the Marathon region, Texas: Washington, DC, U.S.Geological Survey, Professional Paper, núm.187, 148 p.

King, P.B., 1942, Permian of west Texas and southeastern New Mexico: Bulletin of the American Association of Petroleum Geologists, 26, 535-763.

King, P.B., 1948, Geology of the southern Guadalupe Mountains, Texas: Washinton, D.C., U.S. Geological Survey, Professional Paper, núm. 215, 183 p.

King, P.B., 1965, Geology of the Sierra Diablo region: Washington, D. C., U.S. Geological Survey, Professional Paper, núm. 480, 185 p.

King, P.B. 1975. Ancient margin of North America: Geology, 3, 732 734.

King, P.B., 1978, Tectonics and sedimentation of the Paleozoic rocks in the Marathon region, west Texas, in Tectonics and Paleozoic facies of the Marathon geosyncline, West Texas: Society of Economic Paleontologists and Mineralogists, Permian Basic Section, Publication, núm. 78-17, 5-38.

King, P.B., 1980, Geology of the eastern part of the Marathon Basin, Texas: Reston, Virginia, U. S., Geological Survey, Professional Paper, núm. 1157, 40 p.

King, P.B., King, R.E., Knight, J.B., 1945, Geology of Hueco Mountains, El Paso and Hudspeth counties, Texas: Washington, D.C., United States Geological Survey, Oil and Gas Investigations, Preliminary Map, núm. 36, 1 mapa.

King, R.E., Adkins, W.S., 1946, Geology of a part of the lower Rio Conchos valley, Chihuahua, Mexico: Geological Society of America Bulletin, 57, 275-294.

Kluth, C.F., Coney, P.J., 1981, Plate Tectonics of the Ancestral Rocky Mountains: Geology, 9, 10-15.

Kottlowski, F.E., 1958, Pennsylvanian and Permian rocks near the late Paleozoic Florida islands, in $11^{\text {th }}$ Field Conference, Guidebook: Roswell Geological Society, 79-87.

Kottlowski, F.E., 1965, Sedimentary basins of south-central and southwestern New Mexico: American Association of Petroleum Geologists, Bulletin, 49, 2120 - 2139.

Kottlowski, F.E., Foster, R.W., Wengerd, S.A., 1969, Key oil tests and stratigraphic sections in southwestern New Mexico, in Guidebook of the border region; Chihuahua and the United States: New Mexico Geological Society, 186-196.

LeMone, D.V. 1969. Lower Paleozoic rocks in the El Paso area, in, Guidebook of the border region; Chiahuahua and the United States: New Mexico Geological Society, 68-79.

LeMone, D.V., 1985, Preliminary analysis of the hydrocarbon potential of the Paleozoic sequence, southern Hueco Mountains, El Paso and Hudspeth counties, Texas, in Dickerson, P.W., Muehlberger, W.R. (eds.) Structure and tectonics of trans-Pecos Texas: West Texas Geological Society, Publication, núm. 85-81, 239-245.

Limón-González, M., 1986, Evaluación geológico-geoquímica de la provincia de Chihuahua: Boletín de la Asociación Mexicana de Geólogos Petroleros, 38(2), 3-58.

López-Ramos, E., 1969, Marine Paleozoic rocks of Mexico: American Association Petroleum Geologists, Bulletin, 53(12), 2399-2417.

López-Ramos, E., 1988, Geología y aprovechamiento integral de las perforaciones en el altiplano Mexicano: Geomimet, 151, 84-100.

Luff, G.C., 1981, A brief overview and oil and gas potential of the Marfa Basin, in Pearson, B.T. (leader), Marathon; Marfa Region of West Texas, symposium and guidebook: Md, Texas, Society of Economic Paleontologists and Mineralogists, Permian Basin Section, 111-130.

McDowell, F.W., Housch, T.B., Wark, D.A., 1999, Nature of the crust beneath west-central Chihuahua, Mexico, based upon $\mathrm{Sr}, \mathrm{Nd}$, and $\mathrm{Pb}$ isotopic compositions of the Tomochic volcanic center: Geological Society of America Bulletin, 111, 823-830.

Mellor, E.I., Breyer, J.A., 1981, Petrology of late Paleozoic basin-fill 
sandstones, north-central Mexico: Geological Society of America Bulletin, 92, 367-373.

Montgomery, H., 1987, Microfacies and paleographic significance of the Permian patch reefs at Sierra Plomosa, Chihuahua: Universidad Autónoma de Chihuahua, Facultad de Ingeniería; Sociedad Geológica Mexicana, Delegación Chihuahua, Gaceta Geológica, $1(1), 70-81$.

Mosher, S., 1998, Tectonic evolution of the southern Laurentian Grenville orogenic belt: Geological Society of America Bulletin, 110, 1357-1375.

Muehlberger, W.R., 1965, Late Paleozoic movement along the Texas Lineament: New York Academy of Sciences Transactions, series II, 27, 385-392.

Muehlberger, W.R., 1980, Texas lineament revisited, in Dickerson, P. W., Hoffer, J.M., Callender, J.F. (eds.), Trans-Pecos region, southeastern New Mexico and West Texas: New Mexico Geological Society, Guidebook, núm.31, 113-121.

Muehlberger, W.R., Dickerson, P.W., 1989, A tectonic history of Trans-Pecos Texas, in Muehlberger, W.R., Dickerson, P.W. (leaders), Sedimentation and tectonics of western America, volume 3. Structure and stratigraphy of Trans-Pecos Texas: Washington, D.C., American Geophysical Union, 35-54.

Muehlberger, W.R., Denison, R.E., Lidiak, E.G., 1967, Basement rocks in continental interior of United States: American Association of Petroleum Geologists, Bulletin, 51(12), 2351-2380.

Murray, G.E., 1986, Musings about some of the tectonics of the southwestern United States and northern Mexico: The Texas Journal of Science, 38(4), 301-326.

Navarro-G., A., Tovar-R., J., 1974, Stratigraphy and tectonics of the State of Chihuahua, Mexico, in Geologic field trip guidebook thru the states Chihuahua and Sinaloa, Mexico:West Texas Geological Society, Publication, núm. 74-63, 87-91.

Nutt, C.J., O'Neill, M.J., 1998, Geologic framework of Tertiary intrusions of the Cornudas Mountains, southern New Mexico, in Las Cruces Country II. 41th Annual Field Conference: New Mexico Geological Society, 129-134.

Osburg, C., Berge, T., Dowse, M., Dickerson, E., 1985, Road log from Van Horn to Devils Ridge, to Malone Mountains, to Sierra San Ignacio and on to Alpine, in Structure and tectonics of TransPecos Texas: West Texas Geological Society, Publication, núm. 85-81, 17-24.

Pearson, B.T., 1978, Ouachita-Marathon geosynclinal facies in the Green Valley area, Brewster County, Texas, in Mazullo, S.J. (ed.), Tectonics and Paleozoic facies of the Marathon geosyncline West Texas: Midland, Texas, Society of Economic Paleontologists and Mineralogists, Permian Basin Section, Publication, núm. 78-17, 95-100.

Pearson, B.T., 1980, General survey of the oil and gas prospects of Trans-Pecos Texas, in Trans-Pecos region, southeastern New Mexico and West Texas: New Mexico Geological Society, Guidebook, núm. 31, 271-276.

Pearson, B.T., 1981, Some structural problems of the Marfa Basin area, in Pearson, B., leader, Marathon-Marfa region of West Texas; symposium and guidebook: Midland, Texas, Society of Economic Paleontologists and Mineralogists, Permian Basin Section, 59-73.

Pearson, B.T., 1985, Miller Brothers Oil Corporation, No. 1 Thomas 139, Presidio County Texas, in Road Log Third Day, Structure and Tectonics of Trans-Pecos Texas: West Texas Geological Society, Publication, núm. 85-81, 24.

Pearson, B.T., Foley, E., Bridges, D., Ashmore, W., 1964, Optional side trip from Aldama to the Paleozoic outcrops of Sierra del Cuervo: road log, in Geology of Mina Plomosas-Placer de Guadalupe area, Chihuahua, Mexico: West Texas Geological Society, Publication, núm. 64-50, 29-31.

Pérez, C., Charleston, S., Malpica, R., 1984, Una nueva localidad del Paleozoico en México, in VII Convención Nacional, Memoria: México, D.F., Sociedad Geólogica Mexicana, 11-22.

Pol, J.C., 1985, Tectonic controls of late Paleozoic sedimentation, Hueco Mountains, El Paso County, Texas, in Structure and tectonics of Trans-Pecos Texas: West Texas Geological Society, Publication, núm. 85-81, 207-211.
Poole, F.G., Baars, D.L., Drewes, H.D., Hayes, P.T., Ketner, K.B., McKee, E.D., Teichert, C., Williams, J.S., 1967, Devonian of the southwestern United States, in Oswald, D.H. (ed.), International symposium on the Devonian System, v. 1: Calgary, Canada, Alberta Society of Petroleum Geologists, 879-912.

Ramírez-M., J.C., Acevedo-C., F., 1957, Notas sobre la geología de Chihuahua: Boletín de la Asociación Mexicana de Geólogos Petroleros, 9, 583-772.

Ransome, F.L., 1915, Tertiary orogeny of the North American Cordillera and its problems, in Problems of american geology: New Haven, Connecticut, Yale University Press, p. 295, 358 and 369.

Reid, J.C. 1989. Hazel Formation, West Texas: A Precambrian arid region alluvial fan system: Part 1; Fan environments: West Texas Geological Society Bulletin, 28(8), 5-15.

Reyes-Cortés, I. A., Potter, P. E., 1987, Interpretación sedimentológica de la Formación Falomir, en El Cerro de Carrizallilo, Chihuahua, Mexico: Universidad Autónoma de Chihuahua, Facultad de Ingenieria; Sociedad Geológica Mexicana, Delegación Chihuahua, Gaceta Geológica, 1(1), 31-35.

Reynolds, D., 1985, Deformation along the late Precambrian Streeruwitz thrust near Allamoore, Hudspeth County, Texas, in Dickerson, P.W., Muehlberger, W. R. (eds.) Structure and tectonics of Trans-Pecos Texas: West Texas Geological Society, Publication, núm. 85-81, 107-115.

Rix, C.C., 1953, Geology of the Chinati Peak Quadrangle: Austin, Texas, University of Texas at Austin, Ph. D. Thesis, $188 \mathrm{p}$.

Roberts, D.C., 1989, Sedimentation and tectonics of the Cerro Los Panales area, east-central, Chihuahua, Mexico: Austin, Texas, University of Texas at El Paso, M.S. Thesis, 200 p.

Roberts, D.C., Dyer, R., 1988, A preliminary report on the geology of the Cerro Panales area, east-central Chihuahua, Mexico, in Stratigraphy, tectonics and resources of parts of Sierra Madre Occidental province, Mexico, Guidebook: El Paso, Texas, El Paso Geological Society, Guidebook, 159-172.

Romero-Morales, P. R., 1987, Algunas observaciones sobre la geología en la Sierra Samalayuca, Chihuahua: Universidad Autónoma de Chihuahua, Facultad de Ingeniería; Sociedad Geológica Mexicana, Delegación Chihuahua, Gaceta Geológica, 1(1), 160-161.

Ross, C.A., 1973, Pennsylvanian and Early Permian depositional history, southeastern Arizona: American Association of Petroleum Geologists, Bulletin, 57, 887-912.

Ross, C.A., Ross, J.R.P, 1985, Paleozoic tectonics and sedimentation in West Texas, southern New Mexico, and southern Arizona, in Structure and Tectonics of Trans-Pecos Texas: West Texas Geological Society, Publication, núm. 85-81, 221-230.

Santamaría-O., D., Ortuño-A., F., Adatte, T., Ortiz-U., A., Riba-R., A, Franco-N., S., 1991, Evolución geodinámica de la Cuenca de Sabinas y sus implicaciones petroleras, estado de Coahuila: México, D.F., Instituto Mexicano del Petróleo, Subdirección de Tecnología de Exploración, Gerencia de Investigación Aplicada a la Exploración, v. 1, 209 p.

Seager, W.R., 1983, Laramide wrench faults, basement-cored uplifts, and complementary basins in southern New Mexico: New Mexico Geology, 5, 69-76.

Setter, J.R.D., Adams, J.A.S., 1986, Petrology and geochemistry of the Quitman Mountains, Hudspeth County, Texas, in Igneous Geology of Trans-Pecos Texas: Texas Bureau of Economic Geology, Guidebook núm. 23, 178 - 206.

Silver, L.T., Anderson, T.H., 1974, Possible left-lateral early to middle Mesozoic disruption of the southwestern North American craton margin: Geological Society of America Abstracts with Programs, 6,955 .

Sivils, D.J., 1987, Stratigraphy and structure of Sierra de Palomas, Chihuahua, Mexico: Universidad Autónoma de Chihuahua, Facultad de Ingeniería; Sociedad Geológica Mexicana, Delegación Chihuahua, Gaceta Geológica, 1(1), 176-202.

Skinner, J.W., 1940, Upper Paleozoic section of Chinati Mountains, Presidio County, Texas: American Association of Petroleum Geologists, Bulletin, 24, 180-188.

Stevens, C.H., Stone, P., Kistler, R.W., 1992, A speculative reconstruction of the Middle Paleozoic continental margin of southwestern North America: Tectonics, 2, 405-419. 
Stewart, J.H., Roldán-Quintana, J., 1991, Upper Triassic Barranca Group; nonmarine and shallow-marine rift-basin deposits of northwestern Mexico, in Pérez-Segura, E., Jacques-Ayala, J. (eds.), Studies of Sonoran Geology: Boulder, Colorado, Geological Society of America, Special Paper, núm. 254, 19-50.

Stewart, J.H., Suczek, C.A., 1977, Cambrian and latest Precambrian paleogeography and tectonics in the western United States, in Stewart, J. H., Stevens, C.H., Fritsche, A.E. (eds.), Paleozoic, paleogeography of the Western United States: Los Angeles, California, Society of Economic Geologists and Mineralogists, Pacific Section, 1-17.

Swan, M.M., 1975, The Texas lineament; tectonic expression of a Precambrian orogeny: Geological Society of America, Abstracts with Programs, 7, 1288-1289.

Thompson III, S., Tovar-R., J. C., Conley, J. N., 1978, Oil and gas exploration wells in the Pedregosa basin, in Land of Cochise: New Mexico Geological Society, Guidebook, núm. 29, 331-342.

Torres-Espinosa, J. A., Salinas-Hinojosa, C. R., López-Flores, A., 1987, Estratigrafía preliminar del Paleozoico en las áreas de La Vinata y Sierra Azcarate, noroeste de Chihuahua, Mexico: Universidad Autónoma de Chihuahua, Facultad de Ingeniería; Sociedad Geológica Mexicana, Delegación Chihuahua, Gaceta Geológica, 1(1), 203-217.

Uphoff, T.L., 1978, Subsurface stratigraphy and structure of the Mesilla and Hueco bolsons, El Paso region, Texas and New Mexico: Austin, Texas, University of Texas at El Paso, M.S. Thesis, 66 p.

Veldhuis, J.H., Keller, G.R., 1980, An integrated geological and geophysical study of the Salt Basin graben, West Texas, in TransPecos Region: New Mexico Geological Society, Guidebook, núm. 31, 271-276.

Ward, C.A., 1977, Structural geology and tectonic history of Paleozoic rocks in the Sierra de Las Monillas, east-central Chihuahua, Mexico: El Paso, Texas, Texas Christian University, M. S. The- sis , $54 \mathrm{p}$.

Wasserburg, G.J., Wetherill, G.W., Silver, L.T., Flawn, P.T., 1962, A study of ages of the Precambrian of Texas: Journal of Geophysical Research, 67(10), 4021-4047.

Weiblen, P.W., 1993, Midcontinent rift system, in Reed, J.C., Bickford, M.R.E., Houston, R.S., Link, P.K., Rankin, D.W., Sims, P.K., Van Schmus, W.R. (eds.), Precambrian: conterminous U.S.: Boulder, Colorado, Geological Society of America, Geology of North America, v. C-2, 72-81.

Wiley, M.A., 1970, Correlation of geology with gravity and magnetic anomalies, Van Horn-Sierra Blanca region, Trans-Pecos Texas: Austin, Texas, Texas University Austin, Ph. D. Thesis, 331 p.

Wilson, J.L., 1970, Upper Paleozoic history of the western Diablo Platform West Texas and south-central New Mexico, in The geologic framework of the Chihuahua tectonic belt; Symposium in honor of Professor Ronald K. DeFord: Austin, Texas, West Texas Geological Society; University of Texas at Austin, 57-64.

Wilson, J.L. 1987 . The Late Paleozoic history of southern New Mexico and Chihuahua: Universidad Autónoma de Chihuahua, Facultad de Ingeniería; Sociedad Geológica Mexicana, Delegación Chihuahua, Gaceta Geológica, 1(1), 36-53.

Wilson, J.L., 1987b, To persons interested in the Paleozoic outcrops near Nuevo Casas Grandes: Unpublised short report.

Yang, K.-M., Dorobek, S.L., 1995, The Permian Basin of west Texas and New Mexico; Tectonic history of a "composite" foreland basin and its effects on stratigraphic development, in Dorobek, $\mathrm{S}$ L., Ross, G.M. (eds.), Evolution of foreland basins: Tulsa, Oklahoma, Society of Economic Paleontologists and Mineralogists, (Society for Sedimentary Geology), Special Publication, núm. 52, 149-174.

Zeller, Jr., R.A., 1965, Stratigraphy of the Big Hatchet Mountains area, New Mexico: New Mexico Bureau of Mines and Mineral Resources, Memoir, núm. 16, 128 p. 